\title{
Anaerobic Treatment of Domestic Sewage at Low Temperature
}

Tarek A. Elmitwalli 


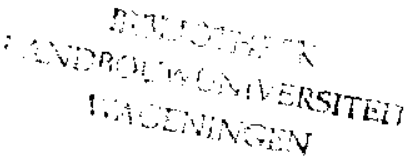

Promotor: dr. ir. G. Lettinga hoogleraar in de anaërobe zuiveringstechnologie en hergebruik van afvalstoffen

Copromotor: dr. ir. G. Zeeman universitair docent bij de sectie Milieutechnologie van het Department Agrotechnologie en Voedingswetenschappen 


\section{Anaerobic Treatment of Domestic Sewage at Low Temperature}

Tarek A. Elmitwalli

\section{Proefschrift}

ter verkrijging van de graad van doctor op gezag van de rector magnificus van Wageningen Universiteit, dr. ir. L. Speelman, in het openbaar te verdedigen op maandag 25 september 2000 des namiddags te vier uur in de Aula 
CIP-DATA KONINKLIJKE BIBLIOTHEEK, DEN HAAG

Elmitwalli, Tarek

Anaerobic treatment of domestic sewage at low temperature / Tarek Elmitwalli. [S.1. :s.n.] Thesis Wageningen University. - With summary in Dutch.

ISBN 90-5808-277-6

Subject headings: anaerobic digestion / wastewater treatment / domestic sewage 
9. Those who speak a lot, work less.

10. Patience is needed for solving problems.

11. Application of death penaity not only is a punishment for the assasinator, but it also works preventive, as it forces the criminal to consider his/her fate before taking action.

12. Any researcher should realize well that what he or she knows, is just a fraction of what he or she should know.

Propositions belonging to the thesis entitled" Anaerobic treatment of domestic sewage at low temperature"

Tarek Elmitwalli

Wageningen, 25 September 2000 


\section{Propositions}

1. The bottle necks of the proposed physical chemical pre-treatment for domestic sewage, recognized by Mels et al. (1999), viz. high sludge production and use of chemicals, can be overcome by the application of an anaerobic filter instead of physical chemical pre-treatment.

Mels A. R., van Nieuwenhuijzen A. F., van der Graaf J. H. J. M., Klapwijk B., de

Koning J. and Rulkens W. H. (1999) Sustainability criteria as a tool in the development of new sewage treatment methods. Wat. Sci. Tech. 39(5), 243-250.

This dissertation (Chapter 5)

2. The design upflow velocity of $1 \mathrm{~m} / \mathrm{h}$ for treating domestic sewage in a UASB reactor recommended by Vieira and Garcia ( 1992) will lead to poor removal of particulate organic matter.

Vieira S. M. M. and Garcia Jr. A. D. (1992) Sewage treatment by UASB reactor. Operation results and recommendations for design and utilization. Wat. Sci. Tech. 25(7), 143-157.

3. Rather than to poor biodegradability, the relatively poor removal of the colloidal fraction from domestic sewage in continuous high-rate anaerobic reactors is due to low physical removal of this fraction.

This dissertation (Chapter 2)

4. As the negative zeta-potential of colloidal particles in domestic sewage remains almost unchanged when the wastewater is exposed to long-term anaerobic digestion, likely also colloidal stability will remain unaffected during anaerobic treatment.

This dissertation (Chapter 2)

5. A high removal of the suspended solids fraction in the first anaerobic step of a twostep AnWT-system treating domestic sewage at low temperature and the presence of an anaerobic biofilm on the filter medium in the second anaerobic step are essential for accomplishment of an efficient removal of the colloidal particles.

This dissertation (Chapter 3, 4 and 6)

6. The statement of Harremoës (1997). "There is no 'low tech' in sight for domestic sewage treatment" is neglecting the possibilities of a DESAR (Decentralized Sanitation and Reuse) system, which enables the application of alternative 'low tech' collection, transport and treatment systems.

Harremoës, P. (1997) integrated water and waste management, Wat. Sci. Tech., 35(9),1120.

7. In developing countries, like Egypt, existing technologies for domestic sewage treatment should be used and upgraded instead of replaced by 'Western high tech'.

8. One person is unable to build a house, but 10 persons easily can build 10 houses. Hasn Fatehy (Egyptian Architecture) 


\section{ACKNOWLEDGEMENTS}

I express my deep gratitude to Prof. Dr. Gatze Lettinga, my promotor, for giving me the opportunity to work at the Sub-Department of Environmental Technology. Thanks to his excellent guidance and support from the first day of my coming to The Netherlands till now. I would like to thank Dr. Grietje Zeeman, my 'daily' guide and co-promotor, for her support, advice, discussion and detailed review with valuable comments on this thesis.

I would like to thank Dr. Arie de Keizer and Dr. Harry Bruning for their co-operation. I also had the opportunity to work, interact and discuss with several students and colleagues from different countries who did work hard and I therefore would like to acknowledge: Marcel Zandvoort, Marco van Dun, Jesko Soellner, Vladimir Sklyar, Kim Oanh.

I acknowledge Hardy Temmink for the Dutch translation of the summary. I am also grateful to Bert Willemsen, Rob Roersrma, Ilse Gerrits-Bennehey, Dieke van Doorn, Ab van der Linde, Remco Fokkink, Ben Spee, Willem Threels, Hans Donker and Johannes van der Laan for technical support. I express my appreciation to Heleen Vos and Liesbeth Kesaulya-Monster for their cordiality and assistance.

I would like to thank all the members of the department, especially Wendy Sanders, Hardy Temmink, Salih Rebac, Robert Kleerebezem, Adriaan Mels, Katarzyna Kujawa-Roeleveld, Ahmed Tawfik, Nedal Mahmoud, Maha Halalsheh, Jules van lier, Joost van Buuren, Look Hulshoff Pol, Sameh Sayed, Jim Field, Vinnie de Wilde, Jan Weijma, Piet Lens, Bram Klapwijk, Wim Rulkens, Miriam van Eekert, Elias Razo Flores, Brian Donlon, Maria Fernandez-Polanco, Francisco Omil, Esnati Chaggu, Lucas Seghezzo and Bas Buys. I express my gratitude to Dora Lettinga for her kind hospitality.

I want to express my deep gratitude and thanks to my wife for supporting me not only during our stay in The Netherlands but also during our engagement in Egypt. She shares me during all hard and good times in The Netherlands and makes life easy and simple. Of course, I thank my son Tarek and my daughter Selma, with them and my wife my life became wonderful.

I want to express my thanks to my father and mother, my first and most important teachers in my life, without their support during all my life steps, I could not do anything. Finally, I want to thank my brothers, sisters and mother, brothers and sisters in-law. 


\section{ABSTRACT}

Elimitwalli, T. A. (2000). Anaerobic treatment of domestic sewage at low temperature. Ph. D. Thesis, Wageningen University, Wageningen, The Netherlands.

The main objective of this thesis was to asses the anaerobic treatment of domestic sewage at low temperature and the possibilities to optimize the performance of high-rate anaerobic systems treating domestic sewage at low temperature.

The anaerobic biodegradability of domestic sewage and its fractions was investigated in batch experiments. The results showed a high potential of anaerobic treatment of domestic sewage due to its high biodegradability ( $74 \%$ ). The results showed a high biodegradability of the colloidal fraction $(86 \pm 3 \%)$ indicating that the low removal of colloidal particles in continuous high-rate anaerobic reactors is due to low physical removal rather than biodegradability.

Both results of batch and continuous experiments demonstrated that the removal of SS prior to anaerobic treatment of domestic sewage not only prevents the deterioration of the methanogenic activity in the anaerobic reactor but also improves the removal of colloidal particles. Therefore, for the pre-treatment (removal of SS) of domestic sewage at a low temperature of $13^{\circ} \mathrm{C}$, a comparison between an anaerobic filter (AF) and an anaerobic hybrid (AH) reactor with flocculant sludge with an HRT of $4 \mathrm{~h}$ was carried out. The media in the AF and the top of the AH reactor were vertical sheets of reticulated polyurethane foam (RPF) with knobs. The sludge in the AF reactor was only attached to the media and all accumulated sludge in the bottom of the AF reactor was wasted regularly to avoid reactor clogging. The AF reactor showed a significantly higher suspended $\mathrm{COD}\left(\mathrm{COD}_{\mathrm{ss}}\right)$ removal $(82 \%)$ than the $\mathrm{AH}$ reactor $(53 \%)$ and the performance of the AF reactor was more stable especially in rainy periods. The results showed that the wasted sludge from the $\mathrm{AH}$ reactor was more stabilized. However, the wasted sludge from the AH still needs post stabilization. Therefore, the AF reactor is recommended for the pre-treatment of domestic sewage at low temperature. The results of batch experiments with RPF media with and without an anaerobic biofilm showed that the removal of $\mathrm{COD}_{s \mathrm{~s}}$ in the $\mathrm{AF}$ reactor is mainly due to physical filtration and entrapment, while the removal of colloidal $\mathrm{COD}\left(\mathrm{COD}_{\mathrm{col}}\right)$ depends on the presence of a biofilm.

The results of the treatment of pre-settled sewage at $13^{\circ} \mathrm{C}$ demonstrated that the $\mathrm{AH}$ reactor with granular sludge has a significantly higher total $\mathrm{COD}\left(\mathrm{COD}_{t}\right)$ removal than the UASB reactor due to the significantly higher $\mathrm{COD}_{\mathrm{col}}$ removal. Therefore, the $\mathrm{AH}$ reactor with granular sludge was selected as a second step for treatment of domestic sewage at low temperature. The performance of the $\mathrm{AF}+\mathrm{AH}$ system treating domestic sewage at a low temperature of $13^{\circ} \mathrm{C}$ at different HRTs was investigated. The results showed that optimization of $\mathrm{COD}_{s s}$ and dissolved $\mathrm{COD}\left(\mathrm{COD}_{\text {dis }}\right)$ in the AF and AH reactor respectively could be achieved with an HRT of $4+4 \mathrm{~h}$ for the two-step system without deterioration of the maximum methanogenic activity of the granular sludge in the AH reactor. For optimization of $\mathrm{COD}_{\mathrm{col}}$ a long HRT of $8 \mathrm{~h}$ is needed in the $\mathrm{AH}$ reactor. With an HRT of $4+8 \mathrm{~h}$ for the two-step $\mathrm{AF}+\mathrm{AH}$ system, a COD, removal efficiency of $71 \%$ was achieved with 92,60 and $55 \%$ removal efficiency for respectively $\mathrm{COD}_{\mathrm{ss}}, \mathrm{COD}_{\mathrm{col}}$ and $\mathrm{COD}_{\text {dis. }}$. 


\section{CONTENTS}

Chapter $1 \quad$ Introduction

Chapter 2 Biodegradability and change of physical characteristics of particles during anaerobic digestion of domestic sewage

Chapter 3 The role of filter media in removing suspended and colloidal particles in an anaerobic reactor treating domestic sewage

Chapter 4 Low temperature treatment of domestic sewage in upflow anaerobic sludge blanket and anaerobic hybrid reactors

Chapter 5 Low temperature pre-treatment of domestic sewage in an anaerobic hybrid and an anaerobic filter reactor

Chapter 6 Treatment of domestic sewage in a two-step system anaerobic filter/anaerobic hybrid reactor at low temperature

Chapter $7 \quad$ Summary, discussion, conclusions and recommendations

Dutch summary, discussion, conclusions and recommendations

Curriculum vitae 
Chapter 1 INTRODUCTION 


\subsection{INTRODUCTION}

Anaerobic digestion is one of the oldest processes applied for the treatment of domestic sewage (McCarty, 1985). The oldest and simplest process is the septic tank (Jewell, 1987), which combines settling and digestion of settled solids from domestic sewage. The first reported installation for the anaerobic treatment of domestic sewage was developed by Louis Mouras in about 1860 (McCarty, 1985). From then onwards, the application of the anaerobic treatment of domestic sewage was studied by various researchers, Scott-Monrief in 1891, Cameron in 1895, Imhoff in 1905, Winslow and Phelps in 1910 and Coulter, Soneda and Ettinger in 1957 (McCarty, 1985). However, with the development and large scale implementation of aerobic processes, application of anaerobic digestion remained mainly limited to the anaerobic digestion of sludge. At present, domestic sewage is treated mainly aerobically. However, due to the oil crises in the seventies and considerable construction, operation, maintenance costs of the aerobic system, many researchers were encouraged to investigate the application of high-rate anaerobic systems for the treatment of domestic sewage. High-rate anaerobic systems have been developed in the last three decades mainly for the treatment of high-strength wastewater. In these systems, the wastewater passes through the anaerobic biomass, where dissolved substrate then is digested and the particulate matter firstly is captured and next digested. Table 1 shows the benefits and drawbacks of anaerobic treatment of domestic sewage in high-rate anaerobic systems.

Table 1. The benefits and drawbacks of anaerobic treatment of domestic sewage in the high-rate anaerobic systems.

\begin{tabular}{ll}
\hline Benefits & Draw backs \\
\hline 1. Efficient in the removal of organic & $\begin{array}{l}\text { 1. Long start-up period when seed } \\
\text { material especially for tropical regions }\end{array}$ \\
(developing countries). & $\begin{array}{l}\text { growth rate of methanogenic } \\
\text { microorganisms is low. }\end{array}$
\end{tabular}

2. Low construction cost and small land requirements as generally at temperatures $>20^{\circ} \mathrm{C}$ high loading rates can be applied.

3. Low operation and maintenance costs, as energy consumption is low and little equipment is needed.

4. Lower sludge production as compared to aerobic and physical-chemical treatment processes.

5. Biogas production, which can be used for energy production.

2. Low pathogen removal.

3. Requirement for post treatment to reach the effluent standards, depending on the requirements for effluent standards.

4. Low removal efficiency of particulate organic material at low temperatures.

5. Risk for odour nuisance from the reduction of sulphate to sulphide.

\subsection{CHARACTERISTICS OF DOMESTIC SEWAGE}

The composition of domestic sewage varies considerably in time and from one place to another. It basically depends on economic aspects, social behavior, climate conditions, water consumption and type and condition of sewer systems (Haskoning and Wageningen, 
1994; Seghezzo et al., 1998). Table 2 shows the composition of domestic sewage from some selected studies. It will be obvious that the big fluctuations in flow, concentration and composition of domestic sewage may affect the efficiency of the anaerobic treatment (Grin et al., 1985, Man et al., 1986 and Wang et al., 1994).

Table 2. Characteristics of domestic sewage from selected studies.

\begin{tabular}{|c|c|c|c|c|c|c|}
\hline $\begin{array}{l}\mathrm{COD}_{1}^{*} \\
(\mathrm{mg} / \mathrm{l})\end{array}$ & $\begin{array}{c}\mathrm{SS} \\
(\mathrm{mg} / \mathrm{l})\end{array}$ & $\begin{array}{l}\text { VSS } \\
(\mathrm{mg} / \mathrm{l})\end{array}$ & $\begin{array}{r}\text { TKN } \\
(\mathrm{mg} / \mathrm{l}) \\
\end{array}$ & $\begin{array}{c}\mathrm{NH}^{+}{ }_{4}-\mathrm{N} \\
(\mathrm{mg} / \mathrm{l})\end{array}$ & $\begin{array}{l}\text { Total P } \\
(\mathrm{mg} / \mathrm{l})\end{array}$ & Reference \\
\hline 500 & 252 & 217 & - & 25 & 6 & Pretorius, 1971 \\
\hline 288 & 118 & 98 & - & 33 & 3 & Kobayashi et al., 1983 \\
\hline 627 & 376 & 297 & 54 & 30 & 10 & $\begin{array}{l}\text { Barbosa and Santanna, } \\
1989\end{array}$ \\
\hline 475 & 190 & 155 & 30 & 14 & 25 & Sanz and Polanco, 1990 \\
\hline 160 & 285 & 230 & 43 & 19 & 44 & Sanz and Polanco, 1990 \\
\hline 585 & 321 & 238 & 88 & 53 & 10 & Garuti et al., 1992 \\
\hline 500 & 150 & 75 & 55 & - & - & $\begin{array}{l}\text { Chudoba and Pannier, } \\
1994\end{array}$ \\
\hline 650 & 217 & - & 57 & 45 & 10 & Wang, 1994 \\
\hline 635 & 356 & 249 & 43 & 40 & - & $\begin{array}{l}\text { Eliosov and Argamon, } \\
1995\end{array}$ \\
\hline 410 & 210 & 195 & 43 & 30 & 7.2 & Orhon et al., 1997 \\
\hline
\end{tabular}

Some biological and physical/chemical processes have already proceeded in the sewer network before the wastewater is reaching the treatment plant (Wang et al., 1995; Odegaard, 1998). For hilly areas, generally aerobic conditions prevail in the wastewater and in the biofilm that will establish on the wall of the sewer. The end result of these conversion reactions is a decreased amount of soluble organic matter and increased particulate organic matter. On the other hand, for flat areas, like The Netherlands, anaerobic conditions will prevail in the sewer and then particulate organic matter will be captured/adsorbed in the biofilm and hydrolyzed to soluble substrate and smaller particles (Odegaard, 1998).

Particulate materials represent the major fraction in domestic sewage. Wang (1994) showed that organic particles, exceeding $0.45 \mu \mathrm{m}$, represent about $70 \%$ of raw domestic sewage. Levine et al. (1985) found also that the contribution of organic particles larger than $0.1 \mu \mathrm{m}$ ranged from $30-85 \%$ of the total amount of organic materials present in presettled domestic sewage. Table 3 shows the distribution and the composition of particulate materials in domestic sewage. Apparently, a major part of the proteins, lipids and carbohydrates consist of particulate matter.

\subsection{ANAEROBIC REMOVAL AND CONVERSION OF ORGANIC MATTER IN DOMESTIC SEWAGE}

\subsubsection{Physical removal of organic matter in domestic sewage}

The removal of domestic-sewage particulate matter in an anaerobic reactor originates mainly from physical processes proceeding in the anaerobic biomass present in the system. 
The sludge bed is acting as a biological filter. Sprouse and Rittmann (1991) who investigated an anaerobic fluidized bed (AFB) system packed with granular activated carbon (GAC), found a better removal efficiency for both suspended and colloidal particles in a column, when the GAC was covered with an anaerobic biofilm as compared to a GAC medium coated with polymer. Based on these findings, they presumed that the anaerobic biofilm on the medium creates more favorable conditions for organic matter capture.

Table 3. The distribution of particulate matter composition in domestic sewage from selected studies.

\begin{tabular}{lcccl}
\hline Parameter & $<1 \mu \mathrm{m}$ & $1-100 \mu \mathrm{m}$ & $>100 \mu \mathrm{m}$ & Reference \\
\hline COD (\%) & 39 & 27 & 34 & Hunter and Heukelekian 1965 \\
& 37 & 23 & 40 & Hunter and Heukelekian 1965 \\
& $14^{\mathrm{a}}$ & - & $86^{\mathrm{b}}$ & Henze and Harremoes (1992) \\
& $20-30$ & - & $70-80^{\mathrm{c}}$ & Odegaard, 1992 \\
& 40 & 26 & 34 & Levin et al., 1985 \\
& 9 & - & $91^{\mathrm{c}}$ & Tiehm et al., 1999 \\
& $29^{\mathrm{d}}$ & $20^{\mathrm{c}}$ & $51^{\mathrm{f}}$ & Wang 1994 \\
Protein (\%) & & & & \\
- as COD & $44^{\mathrm{a}}$ & - & $66^{\mathrm{b}}$ & Henze and Harremoes (1992) \\
- as TS & 29 & 45 & 25 & Levin et al., 1985 \\
Carbohydrate (\%) & & & & \\
- as COD & $29^{\mathrm{a}}$ & - & $71^{\mathrm{b}}$ & Henze and Harremoes (1992) \\
- as TS & 65 & 11 & 24 & Levin et al., 1985 \\
Lipids (\%) & & & & \\
- as COD & $20^{\mathrm{a}}$ & - & $80^{\mathrm{b}}$ & Henze and Harremoes (1992) \\
Nitrogen (\%) & & & & \\
& 36 & 36 & 28 & Hunter and Heukelekian 1965 \\
& 30 & 32 & 38 & Hunter and Heukelekian 1965 \\
& $80^{\mathrm{a}}$ & - & $20^{\mathrm{b}}$ & Henze and Harremoes (1992)
\end{tabular}

Phosphate (\%)

a, $\frac{79}{<1.2 \mu \mathrm{m} ;{ }^{b},>1.2 \mu \mathrm{m} ;{ }^{\mathrm{c}},>1 \mu \mathrm{m} ;{ }^{d},>4.4 \mu \mathrm{m} ;{ }^{\mathrm{c}},<4.4 \text { and }>0.45 \mu \mathrm{m},{ }^{\mathrm{d}},<0.45 \mu \mathrm{m}}$

The particulate can be subdivided in two fractions, i.e. suspended and colloidal part, with particle sizes of respectively exceeding $4.4 \mu \mathrm{m}$ and between 0.45 and $4.4 \mu \mathrm{m}$. The latter size range is not in agreement with the definition for colloidal matter as used in colloid chemistry (Wang et al., 1995; Zeeman et al., 1997).

\subsubsection{Removal of SS}

As SS represent the major COD fraction in domestic sewage, high removal of SS will lead to high removal of $\mathrm{COD}_{\mathrm{t}}$. The removal of large particles in the SS fraction depends mainly on drag forces and settling characteristics. In an anaerobic reactor the removal of SS occurs by settling and by filtration through the sludge bed and/or filter media. The filtration mechanism includes, entrapment, sorption and straining (Metcalf \& Eddy, 1991). The following factors affect the physical removal of SS in anaerobic reactors:- 
- influent concentration: The sedimentation and filtration rate depend on the influent concentration. Grin et al. (1985), Man et al. (1986) and Wang (1994), found that the removal of $\mathrm{COD}_{\text {, }}$ in an upflow anaerobic sludge blanket (UASB) reactor treating domestic sewage depends on influent $\mathrm{COD}_{\mathrm{r}}$.

- temperature: Grin et al. (1985), Man et al. (1986) and Wang (1994) found that the removal of SS in UASB reactors with both flocculant and granular sludge declines when the temperature of domestic sewage decreases. The higher viscosity of the wastewater at lower temperature reduces the sedimentation of particles, as the settling velocity of particles in domestic sewage is inversely proportional to the viscosity of the liquid according to Stokes law.

- height of the reactor: Although the production of biogas causes mixing in the sludge bed and improves the contact between the wastewater and biomass, it also disturbs the sludge bed and reduces the settling of SS in the reactor. In shallow reactors the rate of biogas production per unit area of cross section is lower than in tall reactors. Therefore, the removal of SS in shallow reactor is better than in tall reactor (Man et al., 1986).

- HRT: The HRT has physical and biological effects on the removal of SS. Increasing the HRT improves the settling and filtration in the reactor.

- upflow velocity: with increasing of the upflow velocity at constant HRT and reactor height, the removal of SS by settling will decrease, as the drag force depends on the upflow velocity. Man et al. (1986) found that application of an upflow velocity exceeding $0.5 \mathrm{~m} / \mathrm{h}$ resulted in a significant decrease in SS removal in the treatment of domestic sewage in a UASB reactor at low temperatures.

- particle size and density: wastewater particle size and density play an important role in separation of particles (Levin et al., 1985; Odegraard, 1998), heavier and larger particles settle faster than lighter and smaller particles respectively. Also, the particle size of anaerobic sludge might be an important factor in SS removal as the filtration depends on the size of the filter media. According to Lawler et al. (1986) anaerobic digestion changes the particle size distribution (PSD) of the sludge. They found that when digestion works well, particles of all sizes are destroyed, but there is a preferential removal of particles of small size. When digestion does not work well, large particles are destroyed but small particles are created.

\subsubsection{Removal of colloidal particles}

The removal of colloidal particles, which represent $20-30 \%$ of the $\mathrm{COD}_{\mathrm{t}}$ in domestic sewage clearly is the limiting factor at low temperature treatment (Yoda et al., 1985; Mergaert et al., 1992; Wang, 1994; Sayed and Fergala,1995). According to Sayed and Fergala (1995) the entrapment mechanism involved in removing solids is not sufficient to remove colloidal particles through the sludge bed with high porosity and under upflow and gasification. Last and Lettinga (1992) and Wang (1994) found that colloidal particles in domestic sewage could be removed in a batch recirculation experiment with granular sludge at $20^{\circ} \mathrm{C}$, but only upon applying a long recirculation time $(144 \mathrm{~h})$.

The removal of colloidal particles occurs by filtration and/or sorption in the suspended and/or attached biomass present in the anaerobic reactor. As known, the stability of colloidal matter is governed by Van der Waals attraction and electrostatic repulsion forces. The zela-potential, which represents the potential on or just outside the Stern layer, is an 
important physical parameter for colloidal particle characterization because electrostatic interactions of colloidal particles are mainly related to the zeta-potential. Loosdrecht (1988) found that the adhesion of bacteria, which are colloids and present in domestic sewage, can be described by the Derjaguin, London, Verwey and Overbeek (DLVO) theory for colloidal stability. Moreover, Loosdrecht (1988) demonstrated that bacteria adhesion increases with increasing bacterial hydrophobicity or decreasing negative zeta-potential.

Flocculation, where colloids and fine disperse matter are converted to an aggregated form in which they can be separated, plays an important role on the removal of colloidal matter. The key factors in orthokinetic flocculation are the velocity gradient, G-value $\left(\mathrm{sec}^{-1}\right)$, the energy time input ( $t$ ) and the Gt-value (Camp number). Orthokinetic flocculation due to mixing in a fluidized bed has been observed for domestic sewage without addition of coagulants (Grasmick et al., 1989; Coma et al., 1990) and in a pipe flocculator (Odegaard, 1998). Therefore, it seems that a slight flocculation may take place in an anaerobic reactor treating domestic sewage due to power dissipation from biogas mixing and wastewater flow. The mixing energy due to the biogas flow in the anaerobic reactors mainly depends on organic loading and the height of the reactor (Tilche and Vieira, 1991). Inside a reactor of a given height and given biogas production, the mixing energy of the biogas increases from the bottom to the top of the reactor, following a logarithmic function with increasing derivative (Tilche and Vieira, 1991). Therefore, addition of filter media on the top of the UASB reactor (AH reactor) may improve the removal of colloidal particles not only by filtration but also by flocculation. Also, the microorganisms in the anaerobic reactor have a flocculant growth habit, they produce extracellular polymers, usually polysaccharides, polypeptides or peptidoglycans, which help in bioflocculation and biosorption of particles by bridging (Dugan, 1987; Morgan et al., 1990; Pxon and Darby, 1997).

\subsubsection{Removal of dissolved matter}

High-rate anaerobic systems can efficiently treat, high-strength soluble substrates as well as low-strength soluble substrates even at low temperature (Kato, 1994, Rebac, 1998). Although, the removal of dissolved matter is mainly a biological process, some physical aspects are also involved. A high concentration of active biomass, a good contact between wastewater and biomass, and a good removal of SS are needed for optimization of soluble substrates removal at low temperatures (Agrawal et al., 1997; Rebac, 1998; Lettinga et al., 1999). As the solubility of gases increases at declining temperatures below $20^{\circ} \mathrm{C}$, a lower mixing will prevail in the sludge bed in systems operated at lower temperatures. Moreover, as also viscosity increases at lower temperatures, more energy is required for mixing and diffusion of soluble compounds (Perry and Green, 1984). Rebac (1998) calculated the diffusivity of soluble compounds at various temperatures and concluded that the diffusivity at $10^{\circ} \mathrm{C}$ was $57 \%$ of that at $30^{\circ} \mathrm{C}$.

\subsubsection{Anaerobic conversion of domestic sewage}

\subsubsection{Anaerobic conversion of particulate matter}

Anaerobic digestion is a process that converts organic materials to methane and carbon dioxide in the absence of oxygen. Domestic sewage represents a low-strength complex 
wastewater and contains particulate organic materials such as carbohydrates, proteins and lipids. Anaerobic digestion of particulate organic materials has been described as a multistep process of sequential and parallel reactions, Fig. 1 (Kaspar and Wuhrmann, 1978; Gujer and Zehnder, 1983 and Pavlostathis and Giraldo-Gomez, 1991). Firstly, the particulate are hydrolyzed by extracellular enzymes to soluble products of a such size that they can pass across the cell membrane. These soluble compounds are fermented or anaerobically oxidized to short-chain fatty acids, alcohols, carbon dioxide, hydrogen and ammonia. The short-chain fatty acids (other than acetate) are converted to acetate, hydrogen gas and carbon dioxide. The last step, methanogenesis, occurs from carbon dioxide reduction by hydrogen and from acetate. Zinder (1984) mentioned that the main groups of bacteria and the reactions they mediate are: 1 , fermentative bacteria; 2 , hydrogen-producing acetogenic bactera; 3, hydrogen and carbon dioxide consuming methanogens; 4, acetoclastic methanogens.

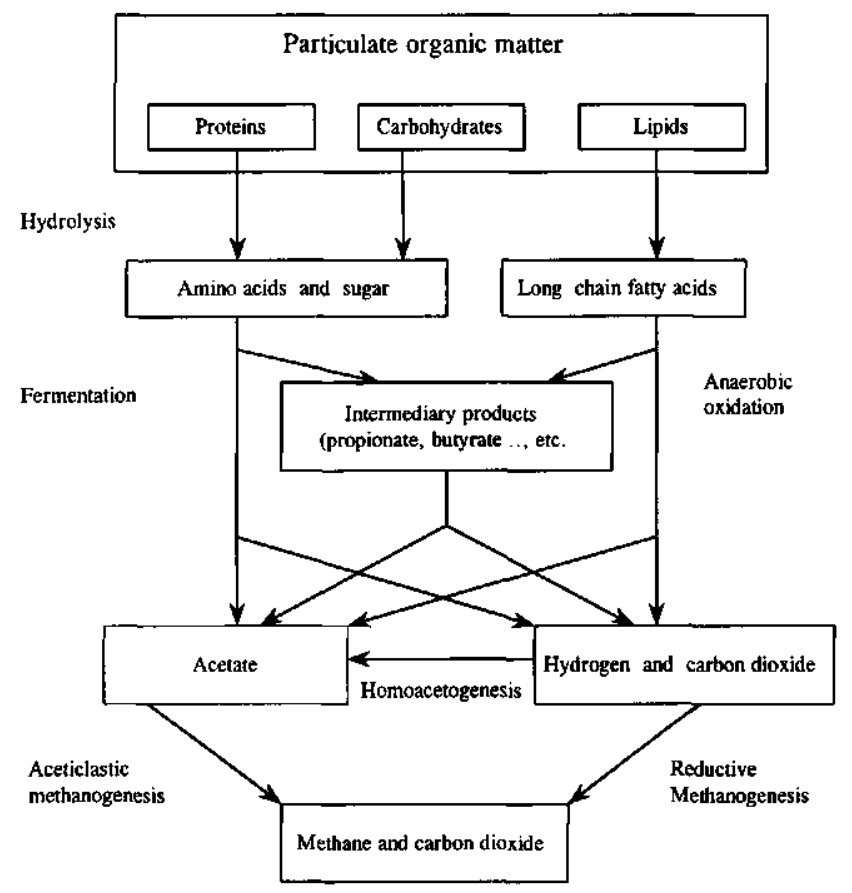

Fig. 1 Reaction scheme for the anaerobic digestion of particulte organic matter. (Adapted from Guijer and Zehnder, 1983).

The hydrolysis of carbohydrates is the rate-limiting step in the anaerobic digestion of carbohydrates (Pavlostaathis, 1988 a, b; Miron et al., 2000). Carbohydrates hydrolyze to soluble carbohydrates. The major products of the fermentation of soluble carbohydrates by anaerobic bacteria in the absence of methanogenic bacteria are ethanol, acetate, hydrogen and carbon dioxide (Wolin, 1979). When hydrogen utilizing bacteria are present, a reduction in the amount of ethanol and an increase in production of acetate is observed (Pavlostaathis and Geraldo-Gomez,1991). 
Proteins are hydrolyzed by extraxcellular enzymes, called proteinases, to amino acids. Solubility, structure and $\mathrm{pH}$ have been found to affect the rate and the extent of protein degradation (McInerney, 1988; Palenzuela-Rollon, 1999). The amino acids produced as a result of protein hydrolysis are fermented further to volatile fatty acids, carbon dioxide, hydrogen gas and ammonium. The fermentation of the amino acids produced during the anaerobic digestion of proteins is fast and therefore the rate-limiting step in the anaerobic digestion of proteins is hydrolysis (Pavlostaathis and Geraldo-Gomez,1991).

The long-chain fatty acids (LCFA) are the main products of lipids hydrolysis by lipase. LCFA are oxidized via $\beta$ oxidation to acetate, propionate and hydrogen. Accumulation of hydrogen results in inhibition of the $\beta$ oxidation (Novak and Carlson, 1970), since it is thermodynamically unfavorable under standard conditions. $\beta$ Oxidation only occurs, when the hydrogen partial pressure is kept low by the presence of hydrogen-scavengers (Miron et al., 2000), e.g. as a permit of presence of methanogenic activity (Miron et al., 2000). Sanders et al. (submitted) hypothesized that the higher hydrolysis of lipids under methanogenic conditions as compared to acidogenic conditions is due to the positive effect of biogas production for maintaining the lipids water interface and subsequent higher hydrolysis rate in methanogenic conditions.

\subsubsection{Effect of sludge residence time (SRT), temperature and wastewater PSD on} anaerobic digestion

The SRT represents one of the most important (design) parameter for both methanogenic and acidifying reactors treating domestic sewage (Zeeman and Lettinga, 1999). According to Miron et al. (2000), studying the role of SRT on anaerobic digestion of primary sludge in completely stirred tank reactor (CSTR) systems at $25^{\circ} \mathrm{C}$, a SRT exceeding 8 days results in methanogenic conditions, where the hydrolysis was the rate-limiting step.

Zeeman and Lettinga (1999) recently proposed a model for calculating the HRT for achieving the needed SRT in the treatment of a complex wastewater, like domestic sewage, using the following equation:

$\mathrm{HRT}=(\mathrm{C} * \mathrm{SS} / \mathrm{X})^{*} \mathrm{R}^{*}(\mathrm{l}-\mathrm{H})^{*} \mathrm{SRT}$

Where: $\mathrm{C}=$ influent $\mathrm{COD}_{1}(\mathrm{mg} / \mathrm{l}) ; \mathrm{SS}=$ suspended $\mathrm{COD}\left(\mathrm{COD}_{\mathrm{ss}}\right) / \mathrm{COD}_{\mathrm{t}} ; \mathrm{X}=$ sludge concentration in the reactor $(\mathrm{mgCOD} / \mathrm{l}, 1 \mathrm{mgVSS} / \mathrm{l}=1.4 \mathrm{mgCOD} / \mathrm{l}) ; \mathrm{R}=$ fraction of the $\mathrm{COD}_{\mathrm{ss}}$ removed; $\mathrm{H}=$ hydrolyzed fraction of removed SS.

Results of calculations based on this model are shown in Fig. 2. The figure shows the effect of $\mathrm{COD}_{\mathrm{ss}}$ removal, the hydrolyzed fraction of the removed SS and SRT on the design HRT (adapted from Zeeman and Lettinga, 1999). From Fig. 2, it is obvious that the design HRT of the anaerobic reactors treating domestic sewage depends on both biological and physical factors, like the removal of SS and the extent of hydrolysis. When either hydrolysis is lower or $\mathrm{COD}_{\mathrm{ss}}$ removal is higher, a longer HRT is needed at a certain SRT.

The rate of hydrolysis for domestic sewage particulate decreases at declining temperature (Wang et al., 1995) which leads to accumulation of SS in the anaerobic reactor, e.g. protein 
and lipids (Gosh, 1987). Zeeman (1991) and Miron et al. (2000) showed that the hydrolysis of respectively cow manure and primary sludge strongly declines with decreasing temperature especially at temperatures below $15^{\circ} \mathrm{C}$. At such low temperatures, the SRT therefore should exceed 100 day in order to retain sufficient methanogenic activity in the anaerobic reactor (Zeeman, 1991; Zeeman and Lettinga, 1999). A decrease in the operational temperature generally leads to a drop in the maximum specific growth rate and specific substrate utilization rate of anaerobic biomass (Lin et al., 1987; Matsushige et al., 1990; Wu et al., 1993). Grin et al. (1985) found that the VFA concentration in the effluent of a $6 \mathrm{~m}^{3}$ UASB reactor treating domestic sewage was higher at $10^{\circ} \mathrm{C}$ as compared to higher temperature.
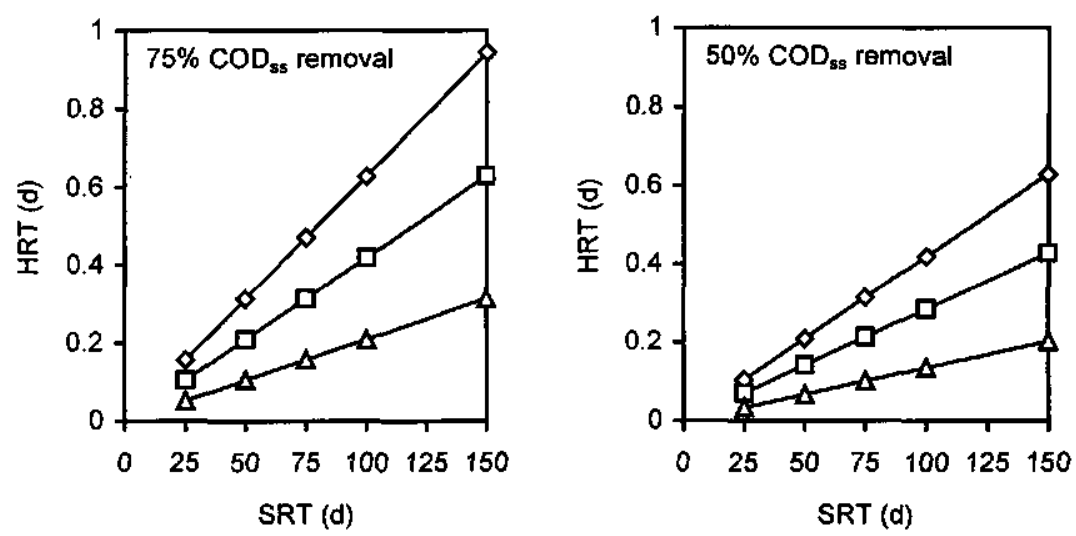

Fig. 2. Calculated HRT for achieving the required SRT, viz. at $50 \%$ or $75 \% \mathrm{COD}_{\mathrm{ss}}$ removal and treating a domestic sewage with a $\mathrm{COD}_{1}$ concentration of $500 \mathrm{mg} / \mathrm{l}, 65 \%$ of which is suspended. The assumed extents of hydrolysis in the calculation were $25 \%(0), 50 \%(\square)$ and $75 \%(\Delta)$ and the assumed sludge concentration in the reactor of $20 \mathrm{gVSS} / 1$ (adapted from Zeeman and Lettinga, 1999).

Hills and Nakano (1984) found that the anaerobic hydrolysis of blended tomato solid waste with different particles diameter is not following first order kinetics and depends on the average particle size. Therefore, they proposed a model, surface based kinetics (SBK), assuming that the hydrolysis rate is constant per unit area available. Also, Hobson (1987) investigated the sensitivity of the SBK model for particles with different shapes. Recently, Sanders et al. (2000) demonstrated a mathematical description of the surface related hydrolysis kinetics for spherical particles in a batch digestion and a verification of this model with particulate starch as a substrate. They found that the theoretical PSD from model calculations showed a good similarity with the obtained experimental PSD, which indicates that the available surface of the particulate substrate is the key factor for the hydrolysis process.

\subsection{HIGH RATE ANAEROBIC SYSTEMS}

High-rate anaerobic systems are capable to retain a high concentration of active biomass, which allows the application of a relatively high loading rate and maintenance of a long 
SRT at a relatively low HRT. Several high-rate anaerobic systems were developed in the last three decades, e.g. the upflow anaerobic filter (AF) reactor (Young and McCarty, 1969), UASB reactor (Lettinga et al. 1979), AFB reactor (Switzenbaum and Jewell, 1980), anaerobic hybrid $(\mathrm{AH})$ reactor (Giuot and Berg, 1984), anaerobic rotating biological contactor (Friedman, 1980), down flow anaerobic filter (Kennedy and Guiot, 1982) and anaerobic baffled reactor (Bachmann et al. 1985). The UASB reactor represents the most frequently applied high-rate anaerobic system, followed by the $\mathrm{AF}$ and the $\mathrm{AH}$ system (Verstraete et al., 1996; Monroy et al., 2000).

\subsubsection{The UASB reactor}

The UASB reactor is the most widely and successfully used high-rate anaerobic systems for several types of wastewaters (Lettinga 1996; Lettinga et al. 1997). The great success of the UASB reactor can be attributed to its capability to retain a high concentration of active suspended biomass with simple and low cost means. Moreover, the formation of granular sludge, which has a high methanogenic activity and is better settable than flocculant sludge, improves the maximum loading rate of the UASB system. Several versions of the upflow anaerobic sludge bed system were developed all on the same basis, like the expanded granular sludge bed (EGSB) reactor (Man et al., 1988), the staged multi-phase anaerobic (SMPA) reactor (Lier, 1995), the high loaded UASB reactor (Wang, 1994; Zeeman et al., 1997) and the upflow acidogenic substrate precipitation (UASP) reactor (Zeeman et al., 1997; Lettinga et al., 1997).

The EGSB reactor, which uses granular sludge at upflow velocities exceeding $6 \mathrm{~m} / \mathrm{h}$, enables the application of treatment for very low strength wastewaters (Kato, 1994) and even for low strength cold wastewaters $\left(<10^{\circ} \mathrm{C}\right)$ (Rebac et al., 1998; Lettinga et al., 1999). The EGSB system also looks very promising for rather toxic substrates (Rinzema, 1988; Razo-Flores et al., 1997; Hwu, 1997; Kleerebezem, 1999). For partial soluble wastewaters in many cases it is useful to separate SS prior to introducing it in the high-rate treatment system. This separation of SS can be accomplished by means of a high loaded UASB system. For specific 'soluble' wastewaters containing emulsified lipids, like dairy wastewaters, the lipid fraction of the substrate can be precipitated and concentrated in a sludge blanket by allowing acidogenesis and a pH-drop (which destabilizes the lipid-protein emulsion), using an UASP reactor concept (Zeeman et al., 1997).

\subsubsection{The AF and AH reactors}

\subsubsection{General}

The AF reactor, a fixed-bed anaerobic reactor, retains the biomass in attached and suspended form. The methanogenic activity in the AF reactor is associated with both suspended and attached biomass to the packing material (Young and Dahab, 1983). The presence of packing materials (PM) constitutes on the other hand an obstacle to horizontal mixing. The system traps large amounts of SS mainly in the lower part of the reactor, where mixing due to the gas production is lowest (Tilche and Vieira, 1991).

Upon applying the $\mathrm{AF}$ on full scale, clogging problems appeared to represent a serious problem especially when using rock as a filter medium (Young, 1991). So, many studies 
were carried out to overcome clogging problems using synthetic media with high porosity and specific surface area. However, the presence of dead zones and channelling especially in the lower part of the filter were not overcome. On the other hand, full scale UASB reactors did not suffer from any clogging problems, but only gave sludge washout when the wastewater quality and/or quantity frequently changes and when it contains large fractions of SS (Tilche and Vieira, 1991).

The AH reactor is a system consisting of a sludge bed in the lower part and an AF in the upper part and combines advantages of UASB and AF reactors, while minimizing their limitations (Kennedy and Guiot, 1986). The filter zone in the $\mathrm{AH}$ reactor, in addition to its physical role for biomass retention, also exerts some biological activity which contributes to COD reduction in a zone where generally active biomass is lacking in a classical UASB reactor (Tilche and Vieira, 1991). Kennedy and Guiot (1986) compared the AH and UASB reactor treating completely soluble synthetic sucrose wastewater. They found that the COD removal efficiency was higher in the AH reactor $(96 \%)$ than the UASB reactor $(83 \%)$. Merwe and Britz (1993) and Cordoba et al. (1995) found that the AH reactor provides a higher COD removal as compared to the AF reactor at the same loading conditions.

According to Iwai and Kitao (1994) the anaerobic biofilm present on PM offers the following advantages: 1) quicker start-up, 2) capability to remove slowly decomposable substrate, 3) higher tolerance to variation in temperature and loading rate, 4) improves the treatment efficiency of low concentration wastewater.

\subsubsection{Effect of the characteristics of PM on reactor performance}

Miyahara and Noike (1994) studied the effect of PM on SS removal and hydrolysis by feeding an anaerobic reactor with a low strength synthetic wastewater $(550 \mathrm{mg} C O D / 1)$ containing cellulose as SS. They found that the effluent water quality is improved remarkably and also the hydrolysis of cellulose was promoted by packing the reactor. Miyahara et al. (1995) studied the relationship between the PM and the behavior of anaerobic bacteria. The number of suspended acidogenic bacteria was found to be higher than the number attached to the PM. On the other hand, they also found more attached than suspended methanogenic bacteria. The accumulation of attached bacteria was promoted by decreasing the HRT of the reactor. The number of acidogenic bacteria in the reactor packed sparsely with PM was higher than that in the closely packed reactor. The number of methanogenic bacteria in the sparsely packed reactor was lower than that in the closely packed reactor.

A large variety of synthetic $\mathrm{PM}$ is used for both the $\mathrm{AH}$ and $\mathrm{AF}$ reactors. On the selection of a suitable $\mathrm{PM}$ in the $\mathrm{AF}$ and $\mathrm{AH}$ reactor, the following considerations on basis of the mentioned studies should be taken into account:-

- The specific surface area of the PM should exceed $100 \mathrm{~m}^{2} / \mathrm{m}^{3}$ even though Young (1991) indicated that increasing specific surface areas above $100 \mathrm{~m}^{2} / \mathrm{m}^{3}$, had a minor effect on the AH performance. Doubling of the specific surface area increased the COD removal efficiency only by less than $5 \%$ (Young, 1991). 
- The PM should have a high porosity in order to reduce the reactor volume occupied by the PM. With proper synthetic media, the porosity can exceed $90 \%$. A higher porosity of the PM decreases the difference between the upflow velocity in the sludge bed and the PM in the $\mathrm{AH}$ reactor. Lower porosity increases this difference, which may lead to back mixing in the sludge bed or clogging of the PM (Tilche and Vieira, 1991). Table 4 presents the porosity and specific surface area of the PM used in selected studies.

- The PM should have a rough surface to promote biofilm formatiom. The surface roughness has an important effect on the primary film forming period and the attached amount of biomass on a rough surface is larger than that on a smooth surface (Kennedy and Droste, 1991; Iwai and Kitao, 1994; Show and Tay, 1999). Iwai and Kitao (1994) compared microbial film attachment of polyvinyl chloride and polyethlene sheets, without (A) and with fine sandpaper (B), and coarse sandpaper (C) in a rotating biological contactor unit. The attaching rates and total attached amount increased in the order, $\mathrm{A}<\mathrm{B}<\mathrm{C}$. Show and Tay (1999) also found that the SRT of an AF reactor with smooth-surface media is lower than that with rough-surface media.

- The PM should be oriented not only to help entrapping and distributing the biomass through PM but also to promote return of excess biomass inside the PM to the sludge bed. A poor orientation of PM may cause channelling, clogging or biomass washout. PM channelling or clogging occurs when biomass is entrapped inside PM, especially in the lower part of the filter zone, and can not be distributed through the PM or return to the sludge bed. Young and Dahab (1983) found that the performance of loose media was lower than of modular corrugated blocks. Biomass washout may occur if the PM is oriented vertically.

Table 4. Porosity and specific surface area of the PM used in selected studies.

\begin{tabular}{|c|c|c|c|}
\hline PM & $\begin{array}{c}\text { Specific } \\
\text { surface area } \\
\left(\mathrm{m}^{2} / \mathrm{m}^{3}\right)\end{array}$ & $\begin{array}{c}\text { Porosity } \\
(\%)\end{array}$ & Reference \\
\hline Synthetic trickling filter media & 144 & 97 & Kobayashi et al. (1983) \\
\hline Modular corrugated blocks & 98 & $>95$ & Young and Dahab (1983) \\
\hline Modular corrugated blocks & 138 & $>95$ & Young and Dahab (1983) \\
\hline Pall rings & 102 & 95 & Young and Dahab (1983) \\
\hline Perforated polypropylene spheres & 89 & $>95$ & Young and Dahab (1983) \\
\hline \multicolumn{4}{|l|}{ Reticulated polyurethane foam:- } \\
\hline a- T10 & 400 & 97 & Huysman et al. (1983) \\
\hline b- T40 & 600 & 97 & \\
\hline c- T80 & 2400 & 97 & \\
\hline $\begin{array}{l}\text { Reticulated polyurethane foam } \\
\text { TR30 }\end{array}$ & 1375 & 97 & Rompu et al. (1990) \\
\hline Raschig rings of sintered glass & 90000 max. & 57 & Anderson et al. (1994) \\
\hline PVC raschig rings & 187 & 75 & Show and Tay (1999) \\
\hline
\end{tabular}

\subsubsection{Reticulated polyurethane foam (RPF)}

The use of porous media, which has high specific surface area and porosity, in anaerobic reactors gave a distinct better performance than non-porous media (Huysman et al., 1983; Anderson et al., 1994). According to Huysman et al. (1983) RPF, porous media, represent 
an excellent colonization matrix. Their findings were confirmed by Fynn and Whitmore (1984), Calzada et al. (1984), Derycke and Verstraete (1986), Gijzen et al. (1988) and Zaiat et al. (1996). The specific surface area of RPF can reach up to $2400 \mathrm{~m}^{2} / \mathrm{m}^{3}$ and a porosity of $97 \%$. Therefore, RPF has the ability to retain a high biomass concentration in attached form, as high as $15 \mathrm{kgVS} / \mathrm{m}^{3}$ media (Rompu et al., 1990; Tilche and Vieira, 1991). Moreover, Zaiat et al. (1996) found that the RPF has the ability to retain the biomass at a high liquid superficial velocity, viz. only $9 \%$ of VSS washed out with a liquid superficial velocity of $80 \mathrm{~m} / \mathrm{h}$. Although the above mentioned characteristics make RPF a suitable PM, a proper orientation of this media is important in order to avoid clogging as found by Rinzema (1988). Rompu et al. (1990) studied the effect of the shape of the RPF (cube or lamellae) on the mass transport. They found that the best flow pattern occurred in the lamella reactors. In such reactors, the effective volume amounted to about $95 \%$ of the theoretical volume. The results of a full-scale $1220 \mathrm{~m}^{3} \mathrm{AH}$ reactor treating starch processing wastewater and containing polyurethane lamellae confirmed that this configuration guarantees a maximum effective volume.

\subsection{PRACTICAL APPLICATION OF ANAEROBIC TREATMENT OF DOMESTIC SEWAGE}

\subsubsection{Anaerobic treatment of domestic sewage under tropical condition}

In tropical areas where the temperature ranges between $20-35^{\circ} \mathrm{C}$, high-rate anaerobic reactors offer a big prospect for the treatment of domestic sewage (Haandel and Lettinga, 1994). Lettinga and his co-workers (Lettinga et al., 1983; Grin et al., 1985; Man et al., 1986; Lettinga et al., 1987; Man et al., 1988) started the research in the anaerobic treatment of domestic sewage in the late seventies. Subsequently, a considerable amount of research has been carried out in this field using a variety of anaerobic reactor types. Table 5 shows results of recent research for the anaerobic treatment of sewage in lab scale reactors at temperature $\geq 20^{\circ} \mathrm{C}$.

Based on the results obtained in a $64 \mathrm{~m}^{3}$ UASB reactor in Cali, Columbia for domestic sewage treatment (Schellinkhout et al., 1985) full scale UASB reactors have been successfully put in operation. The UASB reactor has been considered as the most attractive anaerobic-system for treating domestic sewage due to its simplicity, low investment and operation costs as well as the long favorable experience in the treatment of a wide range of industrial wastewaters (Lettinga and Hulshoff, 1991). According to Monory et al. (2000) the anaerobic treatment of wastewater in Mexico started in 1987 and within one decade, 31 anaerobic reactors, mainly UASB, treating domestic sewage have been installed. The performance and description of these reactors can be found in the article of Monory et al. (2000). Table 6 presents the performance results of full and pilot scale UASB reactors treating domestic sewage. The presented results in Table 5 and 6 reveal that more than $70 \%$ of $\mathrm{COD}_{\mathrm{t}}$ reduction can be accomplished in treating raw domestic sewage.

\subsubsection{Anaerobic treatment of domestic sewage at low temperatures}

The application of anaerobic treatment of domestic sewage is certainly not restricted to tropical regions. From results obtained by Lettinga and his co-workers (Lettinga et al., 
1983; Grin et al., 1983; Last and Lettinga, 1992; Wang; 1994), it is clear that anaerobic treatment of domestic sewage may also represent an attractive and feasible option for moderate climates. However, at low temperatures, more sophisticated reactors are needed (Wang, 1994; Sayed and Fergala, 1995; Lettinga, 1996; Kalogo and Verstraete, 1999). Table 7 presents a summary of results of recent research for the anaerobic treatment of domestic sewage at low temperature $\left(<20^{\circ} \mathrm{C}\right)$. Although the anaerobic treatment of domestic sewage has been applied at full scale in several tropical countries, the process so far is not applied at full scale in countries in temperate climate regions, mainly as a result of the lower removal efficiencies. Moreover, at low ambient temperatures, the amount of SS accumulating in the sludge bed increases (Inamori et al., 1983; Genung et al., 1985; Sanz and Fdz-Polanco, 1990).

Various investigations have been carried out to overcome the obstacles faced the anaerobic treatment of domestic sewage at low temperatures by the following:

\section{Use of granular seed sludge}

Lettinga et al. (1983) studied the effect of using granular sludge for the treatment of domestic sewage. Granular sludge has a higher methanogenic activity and a distinctly better settlability than flocculant sludge. However, as mentioned already above, the treatment of domestic sewage at low temperatures in an one step granular sludge UASB reactor leads to accumulation of SS, due to the slow hydrolysis resulting in deterioration of the methanogenic activity of the sludge (Man et al., 1986; Zeeman and Lettinga, 1999; Uemura and Harada, 2000).

Removing of SS prior to the anaerobic treatment by settling or physical-chemical pretreatment

By treating pre-settled sewage at low temperature not only SS accumulation in the sludge bed is prevented, but it may also promote the formation of granular sludge as was found by Vieira and Souza (1986). According to Kalogo and Verstraete (1999) SS concentration in pre-settled sewage is still high to achieve a stable performance during anaerobic treatment. They report a pre-requested ratio of $\mathrm{COD}_{\text {dis }}$ to VSS in the domestic sewage of more than 10 for achieving an effective and stable treatment. Therefore, Kalogo and Verstraete (2000) applied physical-chemical pre-treatment of domestic sewage prior to anaerobic treatment in a UASB reactor.

\section{Applying high upflow velocities}

In EGSB or AFB reactors, the negative effect of $\mathrm{SS}$ accumulation can be avoided and a good contact between wastewater and biomass at low temperature can be achieved as a result of the high upflow velocity. Last and Lettinga (1992) found a high removal of $\mathrm{COD}_{\text {dis }}$, viz. $84 \%$ of the maximum achievable $\mathrm{COD}_{\text {dis }}$ removal, during the treatment of presettled sewage using an EGSB reactor at an HRT of $2 \mathrm{~h}$ at temperatures $>13^{\circ} \mathrm{C}$. However, an additional settler is needed following an EGSB reactor. Moreover, for achieving the required high upflow velocities in either an EGSB or an AFB reactor a tall reactor and/or recirculation of wastewater has to be applied. Therefore, the use of these systems will be accompanied with higher construction, operation and maintenance costs as compared to the UASB reactor, although the land requirements may be distinctly lower. 


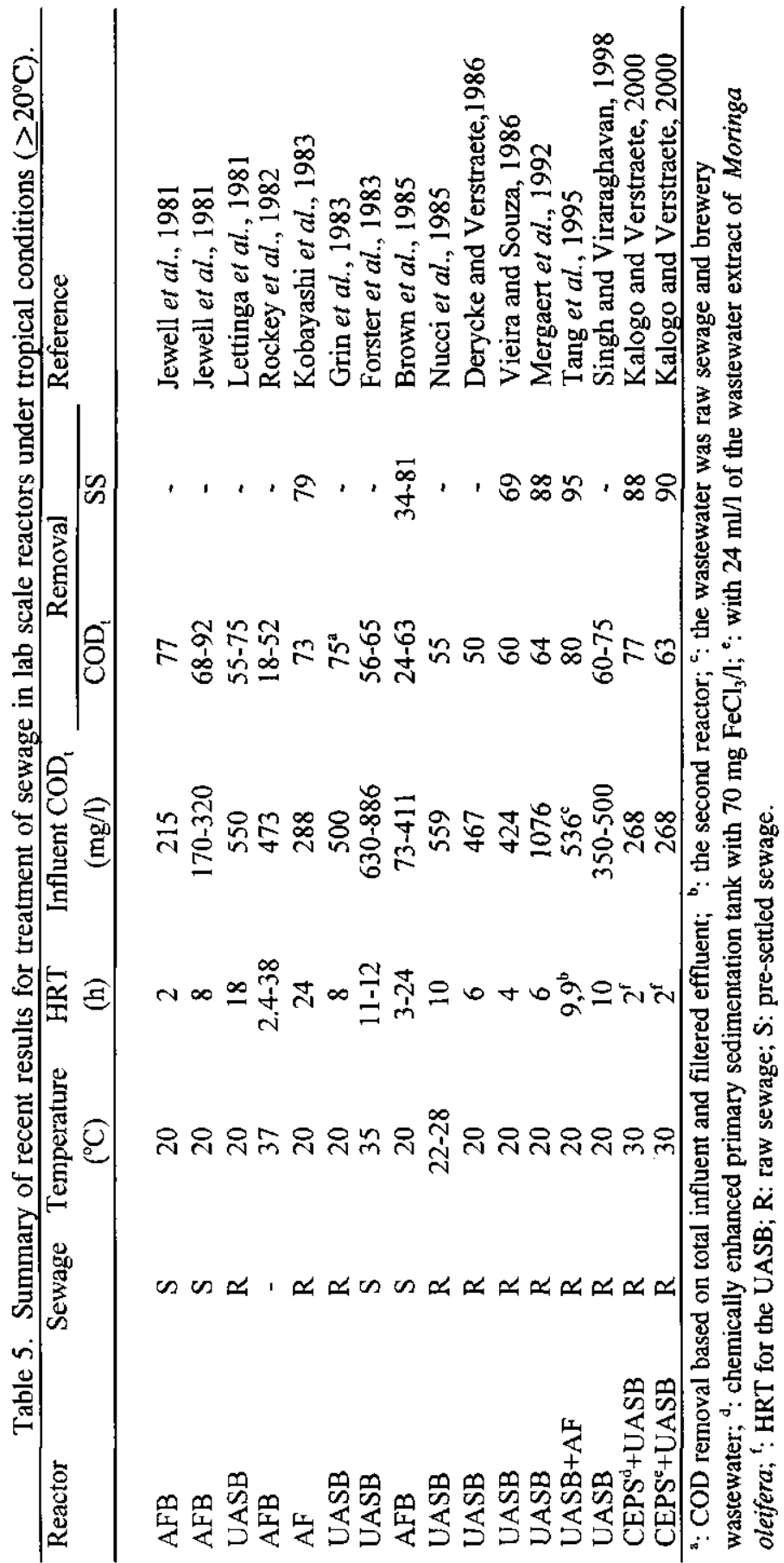




Treatment of raw domestic sewage in a two-step anaerobic system

In the first-step of a two-step system mainly removal of SS and partial hydrolysis and acidification will occur. Due to a slow rate of hydrolysis at low temperatures, the accumulated SS in the first-step need to be discharged regularly. As a result of that, the SRT in the first reactor remains low, therefore preventing the sufficient development of slowly growing methanogens. As most of the SS are removed in this first-step, the removal and conversion of the remaining organic matter can be delegated to the second-step, the methanogenic reactor. As little SS will enter the second-step reactor, the specific methanogenic activity of the sludge remains at a high level. Wang (1994) used a combination of a high loaded UASB + EGSB system for the treatment of domestic sewage at temperatures ranging $12-17^{\circ} \mathrm{C}$ (Table 7). In the flocculant sludge UASB reactor, a substantially higher $\mathrm{COD}_{\mathrm{ss}}$ removal could be accomplished than in a conventional settler as a pre-treatment step. However, the removal of colloidal particles was found to be limited in this combined UASB+EGSB system. Sayed and Fergala (1995) studied the treatment of domestic sewage at temperatures of $18-20^{\circ} \mathrm{C}$ in a two-step system, consisting of three reactors. The first-step consisted of two identical flocculant sludge UASB reactors, which were operated in intermittent mode for the removal and digestion of SS. The second-step was a granular sludge UASB reactor (Table 7). Tang et al. (1995) treated domestic sewage in a two-step UASB+AF system at a temperature of $20^{\circ} \mathrm{C}$ (Table 5). Most of the COD removal was achieved in the first-step (UASB reactor), viz. $70 \%$ of the $80 \%$, which can be attributed to the slightly higher operational temperature of $20^{\circ} \mathrm{C}$.

\subsection{SCOPE OF THIS DISSERTATION}

This thesis describes the results of a research concerning the assessment of the feasibility of anaerobic treatment of domestic sewage at a low temperature of $13^{\circ} \mathrm{C}$. The results described in Chapter 2 deals with the anaerobic biodegradability of various fractions of domestic sewage (suspended, colloidal and dissolved) and assessment of the effect of the degree of anaerobic digestion on physical parameters, like zeta-potential, particle size and surface tension. Chapter 3 focuses on the application of filter media, vertical sheets of RPF with knobs, in removing domestic sewage particulate matter in anaerobic reactors. The experiments presented in Chapter 4 deal with the effect of SS on the performance of UASB and $\mathrm{AH}$ reactors, both with a granular sludge bed, at $13^{\circ} \mathrm{C}$ by comparing the treatment efficiency obtained with raw and pre-settled sewage. Moreover, the difference in performance between UASB and AH reactors was studied and the effect of spacing between the RPF sheets on the performance of the AH reactor was determined. The experiments presented in Chapter 5 deal with a comparison between an $\mathrm{AF}$ and an $\mathrm{AH}$ (with flocculant sludge) reactor for the pre-removal of SS. The AF reactor consisted of a novel system using vertical sheets of RPF with knobs where all biomass was present in attached form to avoid reactor clogging. As the AF reactor provided the best performance for the pre-treatment of domestic sewage (Chapter 5) and the AH reactor with granular sludge showed the best performance for the treatment of pre-treated domestic sewage (Chapter 4), the performance of a combined AF+AH system was investigated in Chapter 6. Different HRTs were imposed to this system. The general discussion and conclusion of the thesis are presented in Chapter 7. 


\subsection{REFERENCES}

Agrawal L.K., Harada H. and Okui H. (1997) treatment of dilute wastewater in a UASB reactor at a moderate temperature: Performance aspects. J. of Fermen. and Bioeng. 83(2), 179-184.

Alphenaar A. (1994) Anaerobic granular sludge: characterization and factors affecting its functioning. Ph. D. thesis, Wageningen University, The Netherlands.

Anderson G. K., Kasapgil B. and Ince O. (1994) Comparison of Porous and Non-porous Media in Upflow Anaerobic Filters when Treating Dairy Wastewater. Water Res. 28(7), 1619-1624.

Bachmann A., Beard V. L. and McCarty P. L. (1985) Performance and characteristics of the anaerobic baffled reactor. Water Res. 19, 99-106.

Barabosa R. A. and Sant'Anna G.L. (1989) Treatment of raw domestic sewage in an UASB reactor. Water Res., 23(12), 1483-1490.

Brown D. C., Mehrotra S., Petrasek A. C. Jr., Eralp A. E., Bishop D. F. and Springer A. M. (1985) Evaluation of anaerobic expanded bed contactors for municipal wastewater treatment. Proc. Seminar/Workshop: Anaerobic Treatment of Sewage, Amherst, Mass., 209-258.

Calzada J. F., Arriola M. C. de, Castaneda J. E., Godoy J. E. and Rolz C. (1984) Methane from coffee pulp juice: Experiements using polyurethane foam reactors. Biotechnol. Lett. 6, 385-388.

Chudoba P. and Pannier M. (1994) Nitrification kinetics activated sludge with both suspended and attached biomasses. Water Sci. Technol. 29(7), 181-184.

Coma J., Jabbouri A. and Elmaleh S. (1990) Flocculation in the fluidized bed. Water Res. 24(3), 361-366.

Cordoba P. R., Francese A. P. and Proimi F. S. (1995) Improved performance of a hybrid design over an anaerobic filter for the treatment of dairy wastewater at laboratory scale. J. of Fermen. and Bioeng. 79(3), 270-272.

Derycke D. and Verstraete W. (1986). Anaerobic treatment of domestic wastewater in a lab and pilot scale polyurethane carrier reactor. Proc. Anaerobic Treatment a Grown-up Technology, Amsterdam, The Netherlands, 437-450.

Draaijer H., Maas J. A. W., Schaapman J. E. and Khan A. (1992) Performance of the 5 MLD UASB reactor for sewage treatment in Kanpur, India. Water Sci. Technol. 25(7), 123133.

Dugan P. R. (1987) The function of microbial polysaccharides in bioflocculation and biosorption of mineral ions. Proc. Flocculation in Biotechnology and Separation Systems. Ed. Y. A. Attia, Elsevier Science Publishers B.V., The Netherlands, 337-350.

Eliosov B. and Argamon Y. (1995) Hydrolysis of particulate organics in activated sludge systems. Water Res. 29(1), 155-163.

Forster C. F. and Wase D. A. (1983) Anaerobic treatment of dilute wastewater using upflow sludge blanket reactor. Environ. Pollut. 31, 57-66.

Friedman A. A., Young K. S., Bailey K. S. and Tait S. J. (1980) New observations with anaerobic fixed film reactors. Proc. Workshop on anaerobic filter. Orlando, Florida.

Fynn G. H. and Whitmore T. N. (1984) Retention of methanogens in colonised reticulated polyuethane foam biomass support particle. Biotechnol. Lett. 6, 81-86. 
Garuti G., Dohanyos M. and Tilche A. (1992) Anaerobic-aerobic combined process for the treatment of sewage with nutrient removal: the ananox process. Water Sci. Technol. 25(7), 383-394.

Genung R. K., Donaldson T. L. and Reed G. D. (1985) Pilot-scale development of anaerobic filter technology for municipal wastewater treatment. Proc. Seminar/Workshop: Anaerobic Treatment of Sewage, Amherst, Mass., 127-160.

Gijzen H. J., Schoenmakers T. J. M., Caerteling C. G. M. and Vogels G. D. (1988) Anaerobic degradation of papermill sludge in a two-phase digester containing rumen microorganisms and colonized polyurethane foam. Biotechnol. Lett. 10, 61-66.

Gosh S. (1987) Improved sludge gasification by two-phase anaerobic digestion. ASCE of Environ. Eng. 113, 1265-1284.

Guiot S. R. and Berg L. van den (1984) Performance and biomass retention of the anaerobic reactor combining a sludge blanket and a filter. Biotech. Lett. 6(3), 161-164.

Guiot S. R. and Berg L. van den (1985) Performance of an upflow anaeric reactor combining a sludge blanket and a filter treating a sugar waste. Biotech. and Bioeng. 27, 800-806.

Gujer W. and Zehnder A. J. B. (1983) Conversion processes in anaerobic digestion. Water Sci. Technol. 15(8/9), 127-167.

Grasmick A., Elmaleh S. and Coma J. (1989) Intensive primary flocculation-sedimentation of urban wastewater. Water Sci. Technol. 21, 631-647

Grin P. C., Roersma R. and Lettinga G. (1983) anaerobic treatment of raw sewage at lower temperatures. Proc. European Symp. Anaerobic Wastewater Treatment, Noordwijkerhout, The Netherlands, 335-347.

Grin P., Roersma R. and Lettinga G. (1985). Anaerobic treatment of raw domestic sewage in UASB reactor at temperature from 9 to $20^{\circ} \mathrm{C}$. Proc. Seminar/Workshop: Anaerobic Treatment of Sewage, Amherst, Mass., 109-124.

Haandel A. C. van and Lettinga G. (1994) Anaerobic Sewage Treatment. John Wiley \& Sons Ltd, England.

Haskoning Consulting Engineers and Architects and Wageningen University (1994) Anaerobic treatment of domestic sewage under tropical conditions. DECOM Manual, Design, Construction, Operation and Maintance of UASB reactors for domestic wastewater. Ministry of Foreign Affaires, The Netherlands.

Henz M. and Harremous (1992) Characterisation of the wastewater. The effect of chemical preciptation on the wastewater composition and its consequences for biological denitrification. In chemical water and wastewater treatment II. ed. R. Klute and Hahn, 299-311.

Hills D. J. and Nakano K. (1984) Effects of particle size on anaerobic digestion of tomato solids waste. Agr. Wastes 10, 285-295.

Hobson P. N. (1987) A model of some aspects of microbail degradation of particulate substrate. J Ferment. Technol 65(4), 431-439.

Hunter J. V. and Heukelekian H. (1965) The composition of domestic sewage fractions. J. Water Pollut. Control Fed. 40, 1905-1919.

Huysman P., Meenen P. van, Assche P. van and Verstraete W. (1983) Factors affecting the colonization of non porous and porous packing materials in model upflow methane reactors. Biotechol. Lett., 5(9), 643-648. 
Hwu C. S. (1997) Enhancing anaerobic treatment of wastewaters containing oleic acids. Ph. D. thesis, Department of Environmental Technology, Wageningen University, The Netherlands.

Imanori Y., Iketani M. and Sudo R. (1983) Effect of temperature on the performance of the anaerobic/aerobic submerged filter system for domestic sewage treatment. J. Sew. Works. Association. 20, 1905-1919.

Iwai S. and Kitao, T. (1994) Wastewater treatment with microbial films. Technomic Publishing Company Inc., USA.

Jewell W. J., Switzenbaum M. S. and Morris J. W. (1981) Municipal wastewater treatment with the anaerobic attached microbial film expanded bed process. $J$. Water Pollut. Control Fed. 53(4), 482-490.

Jewell W. J. (1987) Anaerobic sewage treatment. Environ. Sci. Technol. 21(1), 14-21.

Kalogo Y. and Verstraete W. (1999) Development of anaerobic sludge bed (ASB) reactor technologies for domestic wastewater treatment: motives and perspectives. World $J$. of Microbio \& Biotechnol. 15, 523-534.

Kalogo Y. and Verstraete W. (2000) Technical feasibility of the treatment of domestic wastewater by a CEPS-UASB system. Environm. Technol. 21, 55-65.

Kaspar H. F. and Wuhrmann K. (1978) Kinetic parameters and relative turnovers of some important catabolic reactions in digestion sludge. Appl. Environ. Microbiol. 36, 1-7.

Kato M. T. (1994) The anaerobic treatment of low strength soluble wastewaters. Ph. D. thesis, Department of Environmental Technology, Wagenigen University, The Netherlands.

Kennedy K. J. and Guiot R. L. (1982) Stability and performance of anaerobic fixed film reactors during hyraulic overloading at 10-35 $5^{\circ}$. Water Res. 16, 1391-1398.

Kennedy K. J. and Guiot S. R. (1986) Anaerobic upflow development and application. Water Sci. Technol. 18(12), 71-86.

Kennedy K. J. and Droste, R. L. (1991) Anaerobic wastewater treatment in downflow stationary fixed film reactors. Water Sci. Technol. 24(8), 157-177.

Kleerebezem R. (1999) Anaerobic treatment of phthatates. Ph. D. thesis. Department of Environmental Technology, Wagenigen University, The Netherlands.

Kobayashi H. A., Stenstrom M. K. and Mah R. A. (1983) Treatment of low strength domestic wastewater using the anaerobic filter. Water Res. 17, 903-909.

Last A. R. M. van der and Lettinga G. (1992) Anaerobic treatment domestic sewage under moderate climatic (Dutch) conditions using upflow reactors at increased superficial velocities. Water Sci. Technol., 25(7), 167-178.

Lawler D. F., Chung Y. J., Hwang S. J. and Hull B. A. (1986) Anaerobic digestion: Effect on particle size and dewaterability. J. Water Pollut. Control Fed., 58(12), 1107-1117.

Lettenga G., Velsen L. van, Zeeuw W. de and Hobma S. W. (1979) The application of anaerobic digestion to industrial pollution treatment. Proc. Ist. Int. Symp. on Anaerobic Digestion. 167-186.

Lettinga G., Roersma R., Grin P., Zeeuw de W., Hulshoff Pol L., Velsen L van, Hobma S. and Zeeman G. (1981) Anaerobic treatment of sewage and low strength waste waters. Proc. 2nd. Int. Symp. on Anaerobic Digestion. Travemude, 271-291.

Lettinga G., Roersma R. and Grin P. (1983) Anaerobic treatment of raw domestic sewage at ambient temperatures using a granular bed UASB reactor. Biotech. and Bioeng., 25, 1701-1723. 
Lettinga G., Man A. de, Grin P. and Hulshoff L. (1987) Anaerobic wastewater treatment as a appropiate technology for developing counties. Trib Cebedeau. 519(40), 21-32.

Lettinga G. and Hulshoff L. (1991) UASB-process design for various types of wastewater. Water Sci. Technol. 24(8), 87-107.

Lettinga G. (1996). Sustainable integrated biological wastewater treatment. Water Sci. Technol., 33(3), 85-98.

Lettinga G., Field J., Lier J. van, Zeeman G. and Hulshoff L. (1997) Advanced anaerobic wastewater treatment in the near future. Water Sci. Technol. 35(10), 5-12.

Lettinga G., Rebac S., Parshina S., Noezhvinikova A., Lier J. and Stams A. (1999) Highrate anaerobic treatment of wastewater at low temperatures. J. of Fermen. and Bioeng. 80(5), 499-506.

Levine A. D., Tchobanaglous G. and Asano T. (1985) Characterization of the size distribution of contaminants in wastewater: treatment and reuse implications. J. Water Pollut. Control Fed. 57(7), 805-816.

Lier J. B. van (1995) Thermophilic anaerobic wastewater treatment, temperature aspects and process stability. Ph. D. Thesis, Department of Environmental Technology, Wageningen University, The Netherlands.

Lin C.Y., Noike T., Sato K. and Matsumoto J. (1987) Temperature characteristics of the methanogenesis process in anaerobic digestion. Water Sci. Technol. 19, 299-310.

Loosdrecht M. van (1988) Bacterial adhesion. Ph. D. Thesis, Wageningen University, The Netherlands.

Man A.W.A. de, Grin P.C., Roesma R., Grolle K. C. F. and Lettinga G. (1986) Anaerobic treatment of sewage at low temperatures. Proc. Anaerobic Treatment a Grown-up Technology, Amsterdam, The Netherlands, 451-466.

Man A. W. A. de, Rijs G. B. J., Lettinga G. and Starkenburg W. (1988) Anaerobic treatment of sewage using a granular sludge bed UASB reactor. Proc. 5th. Int. Symp. on Anaerobic Digestion. Bologna, Itly, 735-738.

Matsushige K., Inamori Y., Mizuochi M., Hosomi M. and Sudo R. (1990) The effect of temperature on anaerobic filter treatment for low-strength organic wastewater. Environ. Technol. 11, 899-910.

McCarty P. L (1985) Historical trends in the treatment of dilute wastewaters. Proc. Seminar/Workshop: Anaerobic Treatment of Sewage, Amherst, Mass., 3-16.

McInerney M. J. (1988) Anaerobic hydrolysis and fermentation of fat and proteins. In: Biology of Anaerobic Microorganisms. A. J. B. Zehnder (ed.). John Wiley \& Sons, Inc., New York.

Mergaert K., Vanderhaegen B. and Verstraete W (1992) Application and trends of anaerobic pre-treatment of municipal wastewater. Water Res., 26, 1025-1033.

Merwe M. van der and Britze T. J. (1993) Anaerobic digestion of baker's yeast factory effluent using an anaerobic filter and a hybrid digester. Biores. Technol. 43, 169-174.

Metcalf \& Eddy Inc. (1991) Wastewater engineering, treatment, disposal and reuse. 3rd. edition, McGraw Hill Inc., New York, USA.

Miron Y., Zeeman G., Lier J. van and Lettinga G. (2000) The role of sludge residence time in the hydrolysis of lipids, carbohydrates and proteins during the anaerobic treatment of domestic sewage. Water Res. 34(5), 1705-1713.

Miyahara T. and Noike T. (1994) Behaviour of suspended solids and anaerobic bacteria in an anaerobic fixed bed reactor. Water Sci. Technol., 30(12), 75-86. 
Miyahara T. Takano M. and Noike T. (1995) Role of filter media in an anaerobic fixed bed reactor. Water Sci. Technol., 31(9), 137-144.

Monroy O., Noyola A., Raminez F. and Guiot J. P. (1988) Anaerobic digestion of water hyacinth as a highly efficient treatment process for developing countries. Proc. 5th. Int. Symp. on Anaerobic Digestion. Bologna, Italy, 747-757.

Monroy O., Fama G., Meraz M., Montoya L. and Macarie H. (2000) Anaerobic digestion for wastewater treatment in Mexico: State of the technology. Water Res. 34(6), 18031816.

Morgan J. W., Forster C. F. and Evison L. (1990) A comparative study of the nature of piopolymers extracted from anaerobic and activated sludge. Water Res. 24(6), 743750.

Novak J. T. and Carlson D. (1970) The kinetics of anaerobic long chain fatty acids degradation. J. Water Pollut. Control Fed. 42(2), 1932-1943.

Nucci N. L. R., Giacaglia G. E. O., Nobre P .A., Souza M. E., Vieirra S. M. M., Craveiro A. M. and Gomes I. C. (1985) Anaerobic treatment research, Development and perspective in the state of Sao Paulo, Brazil. Proc. Seminar/Workshop: Anaerobic Treatment of Sewage, Amherst, Mass., 307-350.

Odegaard H. (1992) Norwegian experiences with chemical treatment of raw wastewater. Water Sci. Technol. 25(12) 255-264.

Odegaard H. (1998) Optimised particle separation in the primary step of wastewater treatment. Water Sci. Technol. 37(10), 43-53.

Orhon D., Ates E., Sozen S. and Cokgor E.U. (1997) Characterization and COD fractionation of domestic wastewater. Environment. Polut. 95(2), 191-204.

Palenzuela-Rollon A. (1999) Anaerobic digestion of fish wastewater with especial emphasis on hydrolysis of suspended solids. Ph. D. thesis, Department of Environmental Technology, Wageningen University.

Pavlostathis S. G., Miller T. L. and Wolin M. J. (1988 a) Fermentation of insoluble cellulose by continuous cultures of Ruminococcus albus. Appl. Environ. Microbiol. 54, 2566-2659.

Pavlostathis S. G., Miller T. L. and Wolin M. J. (1988 b) Kinetics of insoluble cellulose by continuous cultures of Ruminococcus albus. Appl. Environ. Microbiol. 54, 2560-2663.

Pavlostathis S.G. and Giraldo-Gomez E. (1991) Kinetics of anaerobic digestion. Water. Sci. Technol. 24(8), 35-59.

Perry R.H. and Green D.W.(1984) Perry's chemical engineers handbook, 6th. eddition, McGraw-Hill Publishing Co., New York.

Poxon T. L. and Darby J. L. (1997) extracellular polyanionics in digested sludge: measurement and relationship to sludge dewaterability. Water Res. 31(4) 749-758.

Pretorius V.A. (1971) Anaerobic digestion of raw sewage. Water Res. 24(4), 463-469

Razo-Flores E. (1997) Biotransformation and biodegradation of $\mathrm{N}$-substituted aromatics in methanogenic granular sludge. $\mathrm{Ph}$. D. thesis. Department of Environmental Technology, Wagenigen University, The Netherlands.

Rebac S. (1998) Psychrophilic anaerobic treatment of low strength wastewaters. Ph. D. thesis. Department of Environmental Technology, Wagenigen University, The Netherlands.

Rinzema A. (1988) Anaerobic treatment of wastewater with high concentration of lipids or sulfate. Ph. D. thesis. Department of Environmental Technology, Wagenigen University, The Netherlands. 
Rockey J.S. and Forster C.F. (1982) The use of an anaerobic expanded bed reactor for the treatment of domestic sewage. Environ. Technol. Lett. 5, 487-496.

Rompu K. van, D'Haene S. and Verstraete (1990) Mass transport in anaerobic polyurethane carrier reactor. Process Biochem. 25(1), 3-6.

Sanders W. T. M., Geerink M., Zeeman G. and Lettinga G. (2000) Anaerobic hydrolysis kinetics of particulate substrate. Water Sci. Technol. . 41(3), 17-24.

Sanders W. T. M., Bosh M. van den, Leenders H., Zeeman G. and Lettinga G. (submitted) The hydrolysis of lipids during anaerobic sludge digestion. Water Res.

Sanz I. and Fdz-Polanco F. (1990) Low temperature treatment of municipal sewage in anaerobic fluidized bed reactors. Water Res. 24(4), 463-469.

Sayed S. K. I. and Fergala M. A. A. (1995) Two-stage UASB concept for treatment of domestic sewage including sludge stabilization process. Water Sci. Technol, 32(11), 5563.

Schellinkout A., Lettinga G., Velsen L. van, Kooymans J. L. and Rodriquez G. (1985) The application of UASB reactor for the direct treatment of domestic wastewater under tropical condition. Proc. Seminar/Workshop: Anaerobic Treatment of Sewage, Amherst, Mass., 259-276.

Schellinkhout A. and Osario C. J. (1992) Full-scale application of the UASB technology for sewage treatment. Water Sci. Technol. 25(7), 157-166.

Seghezzo L., Zeeman G., Jules B.L van, Hamelers H.V.M. and Lettinga G. (1998) A review: The anaerobic treatment of sewage in UASB and EGSB reactors. Biores. Technol. 65, 175-190.

Show K. and Tay J. (1999) Influence of support media on biomass growth and retention in anaerobic filters. Water Res. 33(6), 1471-1481.

Singh K. S. and Viraraghavan T. (1998) Start-up and operation of UASB reactor at $20^{\circ} \mathrm{C}$ for municipal wastewater treatment. $J$. of Ferm. and Bioeng. 85(6), 609-614.

Sprouse G. and Rittmann B. E. (1990) Colloid removal in fluidized-bed biofilm reactor. $J$. of Envron. Eng. 116(2), 314-329.

Switzenbaum M. S. and Jewell W. J. (1980) Anaerobic attached microbial film expanded bed reactor treatment. $J$. Water Pollut. Control Fed. 52(7), 1953-1965.

Tang N. N., Torres C. L. and Speece R. E. (1995) Treatment of low strength domestic wastewater by using upflow anaerobic sludge blanket process. Proc. 50th. Purdue Industrial Waste Conf., 437-448.

Tiehm A., Herwig V. and Neis U. (1999) Particle size analysis for improved sedimentation and filtration in waste water treatment. Water Sci. Technol. 39(4), 99-106.

Tilche A. and Vieira S. M. M. (1991) Discussion report on reactor design of anaerobic filters and sludge bed reactors. Water Sci. Technol., 24(8), 193-206.

Uemura S. and Harada H. (2000) Treatment of sewage by a UASB reactor under moderate to low temperature conditions. Biores. Technol. 72(3), 275-283.

Verstraete W., Beer D. de, Pena M., Lettinga G. and Lens P. (1996) Anaerobic bioprocessing of organic wastes. World J. of Microbio. \& Biotechnol. 12, 221-238.

Vieira S. M. M. and Souza M. E. (1986) Development of technology for the use of the UASB reactor in domestic sewage treatment. Water Sci. Technol. 18(12), 109-121.

Vieira S. (1988) Anaerobic treatment of domestic sewage in Brazil. Research results and fullscale xperience. Proc. 5th. Int. Symp. on Anaerobic Digestion. Bologna, Italy. 185-196.

Wang K. (1994) Integrated anaerobic and aerobic treatment of sewage. Ph. D. thesis, Department of Environmental Technology, Wageningen University, The Netherlands. 
Wang K., Zeeman G. and Lettinga G. (1995) Alteration in sewage characteristics upon aging. Water Sci. Technol. 31(7), 191-200.

Wolin M. J. (1979) The rumen fermentation: a model for microbial interactions in anaerobic ecosystems. Adv. Microbiol. Ecol. 3, 49-78.

Wu W., Thiele J. H., Jain M. K. and Zeikus J. G. (1993) Metabolic properties and kinetics of methanogenic granules. Appl. Microbiol. Biotechnol. 39, 804-811.

Yoda M., Hattori M. and Miyaji Y. (1985) Treatment of municipal wastewater by anaerobic fluidized bed: behavior of organic suspended solids in anaerobic treatment of sewage. Proc. Seminar/Works-hop: Anaerobic Treatment of Sewage, Amherst, Mass., U.S.A., 161-197.

Young J. C. and McCarty P. L. (1969) The anaerobic filter for waste treatment. J. Water Pollut. Control Fed. 41(5), R160-R173.

Young J. C. and Dahab M. F. (1983) Effect of media design on the performance of fixed-bed anaerobic reactors. Water Sci. Technol., 15 (8/9), 369-383.

Young, J. C. (1991) Factors affecting the design and performance of upflow anaerobic filters. Water Sci. Technol., 24(8), 133-155.

Zaiat M., Cabral A. K. A and Foresti E. (1996) Cell wash-out and external mass transfer resistance in horizontal-flow anaerobic immobilized sludge reactor. Water Res. 30(10), 2435-2439.

Zeeman G. (1991) Mesophilic and psychrolphilic digestion of liquid manure. $\mathrm{Ph}$. D. Thesis, Department of Environmental Technology, Wageningen University, The Netherlands.

Zeeman G., Sanders W. T. M., Wang K. Y and Lettinga G. (1997) Anaerobic treatment of complex wastewater and waste activated sludge. Application of upflow anaerobic solid removal (UASR) reactor for the removal and pre-hydrolysis of suspended COD. Water Sci. Technol.35(10), 121-128.

Zeeman G. and Lettinga G. (1999) The Role of anaerobic digestion of domestic sewage in closing the water and nutrient cycle at community level. Water Sci. Technol. 39(5), 187-194.

Zinder S. H. (1984) Microbiology of anaerobic conversion of organic wastes to methane: recent developments. ASM News, 50, 294-298. 


\section{Chapter 2}

\section{BIODEGRADABILITY AND CHANGE OF PHYSICAL CHARACTERISTICS OF PARTICLES DURING ANAEROBIC DIGESTION OF DOMESTIC SEWAGE}

Submitted as:

Elmitwalli T. A., Soellner J., de Keizer A., Bruning H., Zeeman G. and Lettinga, G. (submitted) Biodegradability and change of physical characteristics of particles during anaerobic digestion of domestic sewage. Water Res. 


\title{
BIODEGRADABILITY AND CHANGE OF PHYSICAL CHARACTERISTICS OF PARTICLES DURING ANAEROBIC DIGESTION OF DOMESTIC SEWAGE
}

\begin{abstract}
At the high-rate anaerobic treatment of domestic sewage, both biological and physical processes play an important role. Therefore, the anaerobic biodegradability of raw, paperfiltered and membrane-filtered sewage and black water has been investigated in batch experiments. Additionally, the effect of anaerobic digestion on physical characteristics, like particle size, surface tension and zeta-potential, of the present particles is studied. The biodegradability of domestic sewage and black water at $30^{\circ} \mathrm{C}$ is almost similar $(71-74 \%)$. Moreover, a high methanogenesis of the colloidal fraction in domestic sewage $(86 \pm 3 \%)$ is achieved, showing that the low removal of colloidal particles in continuous high-rate anaerobic reactors is due to low physical removal rather than biodegradability. The lowest biodegradability is demonstrated for the dissolved fraction $(62 \%)$. The results show that after anaerobic digestion the average radius of particles with diameter $<4.4$ and $<0.45 \mu \mathrm{m}$ increased for domestic sewage, while it decreased for black water. Part of the surfaceactive components in domestic sewage is not biodegraded during anaerobic batch digestion, as indicated by the development of the surface tension. The negative zeta-potential of all particles hardly changes during digestion, showing that colloidal interactions were not affected by anaerobic digestion.
\end{abstract}

\section{KEYWORDS}

Anaerobic treatment; domestic sewage; black water; biodegradability; particle size; surfactants; zeta-potential.

\section{INTRODUCTION}

Several authors have shown that particles represent the major part, up to $85 \%$, of the total $\mathrm{COD}\left(\mathrm{COD}_{\mathrm{t}}\right)$ in domestic sewage (Levine et al., 1985; Zeeman et al., 1997). The separation of particulate and dissolved compounds in domestic sewage is usually made by filtration through a membrane filter with a pore diameter of approximately $0.45 \mu \mathrm{m}$ (Nielsen and Harremoes, 1995). The particles are often separated in a suspended and a colloidal part, with a particle size of respectively larger than $4.4 \mu \mathrm{m}$ and between 0.45 and $<4.4 \mu \mathrm{m}$, although the size range for colloidal particles is not in agreement with the definition as used in colloid chemistry (Wang et al., 1995; Zeeman et al., 1997).

At treatment under anaerobic conditions, colloidal $\mathrm{COD}\left(\mathrm{COD}_{\mathrm{col}}\right)$ from domestic sewage is removed to a lower degree than under aerobic or micro-aerophillic conditions and represents $60-80 \%$ of the effluent $\mathrm{COD}_{\mathrm{t}}$ of an anaerobic reactor (Yoda et al., 1985; Wang, 1994; Wang et al., 1995). The removal of $\mathrm{COD}_{\mathrm{col}}$ in batch recirculation experiments at long retention times, indicates however that colloidal particles are biodegradable (Last and Lettinga, 1992; Wang, 1994). So far this has never been proven. 
At the high-rate anaerobic treatment of domestic sewage, both biological and physical processes play an important role. Particles can only be converted via hydrolysis, after being physically removed by sorption, settling or entrapment in the sludge bed. Particle characterization based on biological and physical aspects are therefore of the same importance.

The presence of surfactants in domestic sewage, which are known to adsorb at both solid/liquid and liquid/air interfaces, may affect the anaerobic biodegradability of particles. Surfactants have the ability to emulsify poorly soluble hydrophobic compounds in water, thus potentially improving the accessibility of these substrates to microorganisms (Rouse et al., 1994). On the other hand, the emulsifying effect might prevent the physical removal of the particles. Moreover inhibition of anaerobic biodegradation of organic compounds in the presence of surfactants have also been reported (Wagener and Schink, 1987; Rouse et al., 1994). Boller (1994) mentioned that the surfactant concentration in Zürich City wastewater was 17-22 $\mathrm{mg} \mathrm{l}^{-1}$ and the non-ionic and anionic surfactants represent the main part (91$94 \%$ ). Linear alkylbenzene sulphonates constitutes the major anionic surfactant fraction in households (Holt et al., 1998) with average concentrations of 4 and $3 \mathrm{mg}^{-1}$ in domestic sewage in The Netherlands (Water and Feijtel, 1995) and in UK (Holt et al., 1998) respectively. At low concentrations, surfactants are present as monomers. Micelles are formed above the critical micelle concentration (CMC). The CMC of dodecyl benzene sulphonate amounts to $264 \mathrm{mg} \mathrm{l}^{-1}$ (Mukerjee and Mysels, 1971). Therefore, surfactants in domestic sewage seem to be present as monomers.

The size of particles in domestic sewage affects both biological and physical processes (Levine et al., 1985). Gravitational and drag forces predominate over colloidal forces (van der Waals attraction and electrostatic repulsion) for larger particles, while colloidal forces are more important for particles less than a few $\mu \mathrm{m}$ (Gregory, 1993). The zeta-potential, which represents the potential on or just outside the Stern layer, is an important physical parameter for colloidal particle separation because electrostatic interactions of colloidal particles are mainly related to the zeta-potential.

This research aims at the determination of the anaerobic biodegradability of the suspended, colloidal and dissolved fraction of domestic sewage and black water. Moreover the change in physical characteristics, like particle size, zeta-potential and surface tension as a result of biodegradation is determined.

\section{MATERIALS AND METHODS}

\section{Anaerobic digestion of domestic sewage and black water}

Anaerobic batch digestion has been carried out in duplicate series of serum bottles of $120 \mathrm{ml}$ each at each temperature. To each bottle $100 \mathrm{ml}$ of wastewater is added. The biogas composition in the headspace of each bottle is monitored in time. For each bottle, COD fractions, volatile fatty acids (VFA), and surface tension were determined.

Two series of experiments have been performed. In the first run, raw and paper-filtered sewage was digested at 4,20 and $30^{\circ} \mathrm{C}$ and the bottles were monitored after $8,15,23$ and 43 days. The aim of the second run was to confirm the results of the first run and to find the 
maximum conversion of wastewater to methane (biodegradability). The second run was performed with raw, paper-filtered and membrane-filtered (not in duplicate) sewage and black water at 20 and $30^{\circ} \mathrm{C}$ and monitoring was carried out after 15, 28 and 135 days. In the second run also the average particle radius and zeta-potential were measured.

\section{Analysis}

COD was analysed using the micro-method as described by Jirka and Carter (1975). Raw samples were used for $\mathrm{COD}_{t}, 4.4 \mu \mathrm{m}$ folded paper-filtered (Schleicher \& Schuell 5951/2, Germany) samples for $\mathrm{COD}_{\mathrm{p}}$ and $0.45 \mu \mathrm{m}$ membrane-filtered (Schleicher \& Schuell ME 25 , Germany) samples for dissolved COD $\left(\mathrm{COD}_{\mathrm{dis}}\right)$. The suspended $\mathrm{COD}\left(\mathrm{COD}_{\mathrm{ss}}\right)$ and $\mathrm{COD}_{\mathrm{col}}$ were calculated by the differences between $\operatorname{COD}_{\mathrm{t}}$ and $\mathrm{COD}_{\mathrm{p}}, \mathrm{COD}_{\mathrm{p}}$ and $\mathrm{COD}_{\mathrm{dis}}$ respectively. In the experiments it was difficult to have representative samples for COD due to the formation of large flocs during anaerobic digestion. Therefore, only $\operatorname{COD}_{\mathrm{p}}$ and $\mathrm{COD}_{\text {dis }}$ are presented. VFA was determined from membrane-filtered samples by gas chromatography. The chromatograph (Hewlett Packard 5890A, Palo Alto, USA) was equipped with a $2 \mathrm{~m} \times 2 \mathrm{~mm}$ (inner diameter) glass column, packed with Supelco port (100120 mesh) coated with $10 \%$ Fluorad FC 431 . Operating conditions were: column, $130^{\circ} \mathrm{C}$; injection port, $200^{\circ} \mathrm{C}$; flame ionisation detector, $280^{\circ} \mathrm{C} . \mathrm{N}_{2}$ saturated with formic acid at $20^{\circ} \mathrm{C}$ was used as a carrier gas $(30 \mathrm{ml} / \mathrm{min})$. The biogas composition $\mathrm{CH}_{4}, \mathrm{CO}_{2}, \mathrm{~N}_{2}$ and $\mathrm{O}_{2}$ was determined in a $100 \mu \mathrm{l}$ sample using Fisons instrument gas chromatography model GC 8000 series, equipped with columns connected in parallel (split 1:1)-(1.5 m x $2 \mathrm{~mm}$ ) Teflon, packed with chromosorb $108,(60-80 \mathrm{mesh})$, and a $(1.2 \mathrm{~m} \mathrm{x} 2 \mathrm{~mm})$ stainless steel, packed with molecular sieve $5 \mathrm{~A},(60-80 \mathrm{mesh})$. Helium was used as carriers gas $(45 \mathrm{ml} / \mathrm{min})$. The oven, detector and injection temperature were $40^{\circ} \mathrm{C}, 100^{\circ} \mathrm{C}$ and $110^{\circ} \mathrm{C}$ respectively. All measurements were performed in duplicate.

An indication of the presence of surface-active components can be obtained by measuring the surface tension with the Wilhelmy-plate method. It is likely that in domestic sewage, surfactants will strongly contribute to the lowering of the surface tension of the aqueous solution. After the CMC, surface tension becomes almost independent of the overall concentration. However, one should be aware that also other surface-active components can contribute to the lowering of the surface tension and therefore the qualitative interpretation can be presented. In run 1 , the surface tension was measured for the original samples without filtration. The formation of large flocs during run 1 increased the standard deviations of the surface tension measurements. Moreover, as the surface tension of wastewater slightly increases after paper-filtration (from the results of run 1), the surface tension in run 2 was measured for the samples after paper and membrane filtration. For the fresh samples of raw sewage and black water used in run 2 after paper-filtration, the surface tension was determined after dilution with distilled water to a dilution of $2,4,8$ and 16 times of the initial sample.

The hydrodynamic particle radius was determined with dynamic light scattering. Measurements were carried out in a 2-ml cylindrical quartz cell using an ALV5000 system with a Lexel $150-\mathrm{mW}$ multi line Ar-laser. Particles with a radius between $2.5 \mathrm{~nm}$ to $5 \mu \mathrm{m}$ can be detected. The measurements were performed for both paper-filtered and membranefiltered samples. For each sample, the average particle radius was measured 7 times at an angle of $90^{\circ}$. 
Electrophoretic mobilities were determined with a Malvern Zetasizer III. Zeta-potentials were calculated from the Smoluchowski equation. Measurements were performed at constant ionic strength $(0.02 \mathrm{M} \mathrm{KCl})$ and samples were paper filtered to remove big particles.

\section{Calculations}

The total $\mathrm{CH}_{4}$ production in each serum bottle was the summation of the $\mathrm{CH}_{4}$ in the headspace and the dissolved $\mathrm{CH}_{4}$. The dissolved $\mathrm{CH}_{4}$ was calculated according Henry's law. Percentage of hydrolysis $(\mathrm{H})$, acidification $(\mathrm{A})$ and methanogenesis $(\mathrm{M})$ were calculated according to equations 1,2 and 3 respectively.

$$
\begin{aligned}
& H(\%)=100\left(\frac{C H_{+} \text {as } C O D+\text { effluent } C O D_{\text {dis }}-\text { influent } C O D_{\text {dis }}}{\text { influent } C O D_{1}}\right) \\
& A(\%)=100\left(\frac{C H_{+} \text {as } C O D+\text { effluent VFA as } C O D-\text { influent VFA as } C O D}{\text { influent } C O D_{1}}\right) \\
& M(\%)=100\left(\frac{C H_{+} \text {as } C O D}{\text { influent } C O D_{1}}\right)
\end{aligned}
$$

$\mathrm{H}, \mathrm{A}$ and $\mathrm{M}$ of $\mathrm{COD}_{\mathrm{col}}$ for domestic sewage in run 2 were calculated by subtracting the results of membrane-filtered sewage from the results of paper-filtered sewage and applying equations 1, 2 and 3 respectively. Similarly, $H, A$ and $M$ of $C O D_{s s}$ for domestic sewage in run 2 were calculated by subtracting the results of paper-filtered sewage from the results of raw sewage.

\section{RESULTS AND DISCUSSION}

\section{Biodegradability}

Table 1 summarizes the calculated percentages of hydrolysis, acidification and methanogenesis for each wastewater sample after 43 and 135 days of digestion, in run 1 and 2 respectively. The results of run 1 show that 43 days of batch digestion are not sufficient for complete anaerobic digestion even at $30^{\circ} \mathrm{C}$. The VFA concentration exceeds $100 \mathrm{mg} \mathrm{COD} / \mathrm{l}$ at all applied conditions. The results of the total $\mathrm{CH}_{4}$ production in mu 2 (Fig. 1) show that the maximum conversion of the domestic sewage fractions and black water is achieved after about 80 days at $30^{\circ} \mathrm{C}$. From Fig. 1 it follows that the anaerobic digestion has a characteristic lag-phase period depending on the temperature and the size of the particles. At $20^{\circ} \mathrm{C}$ only raw sewage reached the maximum conversion after 135 days of digestion. The maximum methanogenesis for raw sewage was similar at temperatures of 20 and $30^{\circ} \mathrm{C}$ indicating that anaerobic treatment is not only a promising technique in tropical but also in moderate-temperature areas.

The biodegradability of black water, raw sewage and paper-filtered sewage at $30^{\circ} \mathrm{C}$ is approximately the same, viz. $71-74 \%$, while that of the membrane filtered fraction was relatively low $(62 \%)$. No reported data are available to compare with the presented results. 
Chapter 2

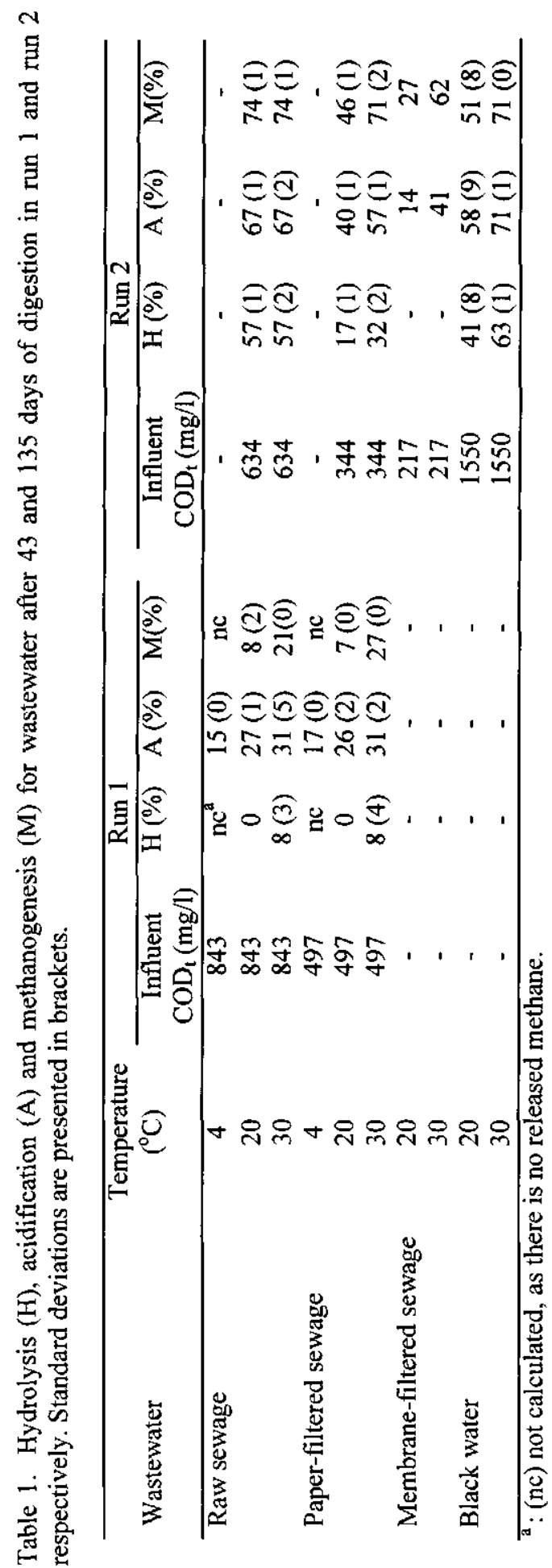



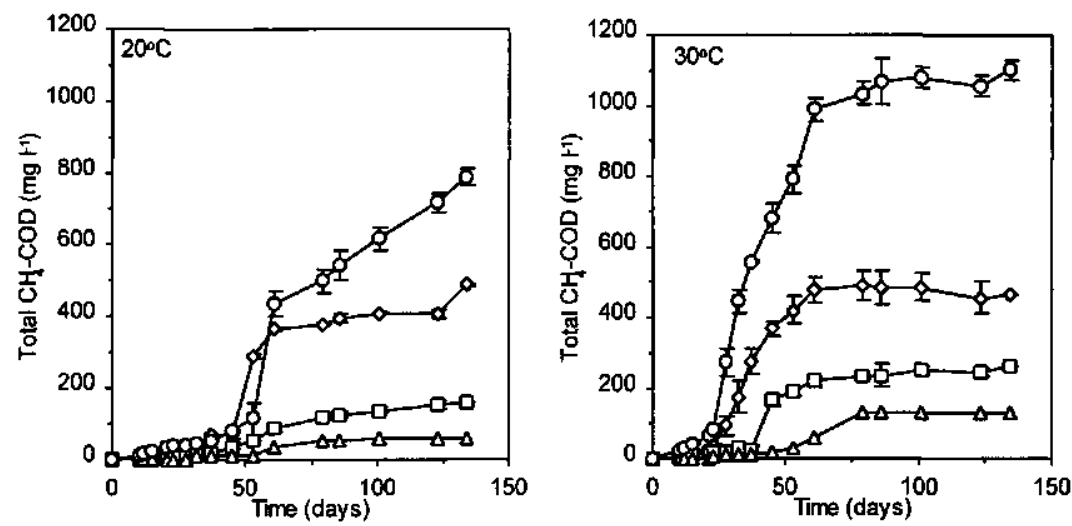

Fig. 1. The course of the total $\mathrm{CH}_{4}$ production during the anaerobic batch digestion of raw sewage $(0)$, paper-filtered sewage $(\square)$, membrane-filtered sewage $(\Delta)$ and black water $(O)$ in run 2 at temperature of 20 and $30^{\circ} \mathrm{C}$.

Table 2 presents the maximum hydrolysis, acidification and methanogenesis of the $\mathrm{COD}_{\mathrm{ss}}$ and $\mathrm{COD}_{\mathrm{col}}$ fraction of domestic sewage at $30^{\circ} \mathrm{C}$. The maximum hydrolysis for $\mathrm{COD}_{\mathrm{ss}}$ and $\mathrm{COD}_{\mathrm{col}}$ is similar, while the maximum acidification and methanogenesis are higher for $\mathrm{COD}_{\mathrm{col}}$ as compared to $\mathrm{COD}_{\mathrm{ss}}$. Hydrolysis of suspended particles seems to produce more non-degradable $\mathrm{COD}_{\text {dis }}$ than hydrolysis of colloidal particles. Last and Lettinga (1992) reported a lower maximum removal of $\mathrm{COD}_{\text {dis }}$ of $54 \%$ during batch recirculation of presettled sewage of the same origin as used in the here presented experiments. This lower biodegradability might be due to the production of non-degradable $\mathrm{COD}_{\mathrm{dis}}$ from the hydrolysis of particles present in pre-settled sewage. The production of non-degradable $\mathrm{COD}_{\text {dis }}$ from particles hydrolysis, results in an increased non-VFA-paper filtered COD, as shown in Fig. 2, for both 20 and $30^{\circ} \mathrm{C}$.

Table 2. The calculated maximum hydrolysis, acidification and methanogenesis for $\mathrm{COD}_{\mathrm{ss}}$ and $\mathrm{COD}_{\mathrm{col}}$ in domestic sewage at $30^{\circ} \mathrm{C}$ in run 2 . Standard deviations are presented in brackets.

\begin{tabular}{lccc}
\hline COD fractions & Hydrolysis (\%) & Acidification (\%) & Methanogenesis (\%) \\
\hline COD $_{s s}$ & $87(5)$ & $78(4)$ & $77(4)$ \\
$\mathrm{COD}_{\mathrm{col}}$ & $88(3)$ & $86(3)$ & $86(3)$ \\
\hline
\end{tabular}

\section{Surface tension}

The surface tension is a measure for the presence of surface-active compounds, such as detergents. The development of the surface tension in time during both run 1 and 2, was almost similar for temperatures of 20 and $30^{\circ} \mathrm{C}$ (Fig. 3 and 4). The maximum surface tension was however much lower at $4^{\circ} \mathrm{C}$ as compared to that at temperatures of 20 and $30^{\circ} \mathrm{C}$. A plateau value on the surface tension is obtained between $15-25$ days. This period is much shorter than the characteristic anaerobic digestion time. It seems that a small amount of highly surface-active components are rapidly decreased. Degradation of the detergents seem much slower leading to a limiting surface tension much lower than that of water ( 72 $\mathrm{mN} / \mathrm{m})$. 

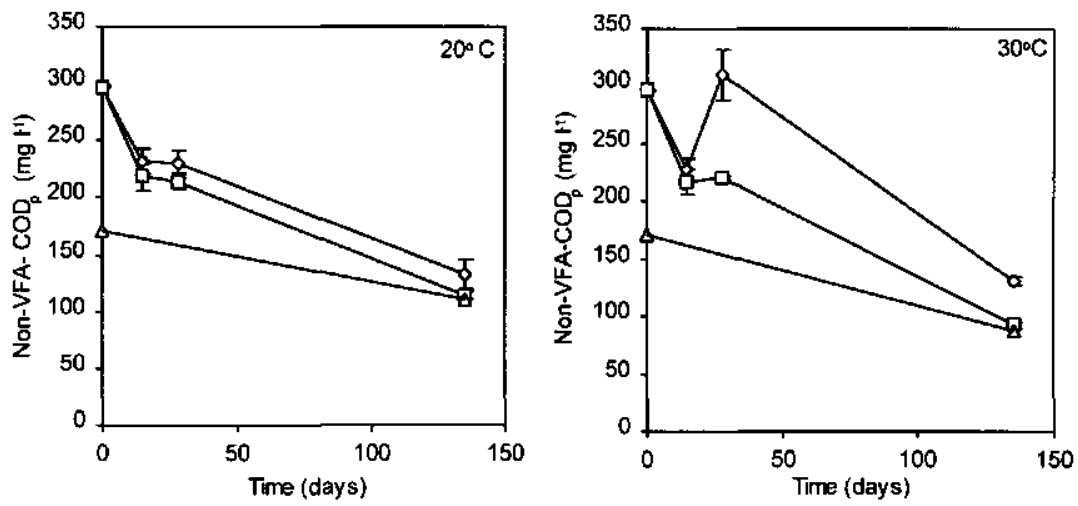

Fig. 2. The course of the non-VFA-paper filtered COD during the anaerobic batch digestion of raw sewage $(0)$, paper-filtered sewage $(\square)$ and membrane-filtered sewage $(\Delta)$ in run 2 at temperature of 20 and $30^{\circ} \mathrm{C}$.
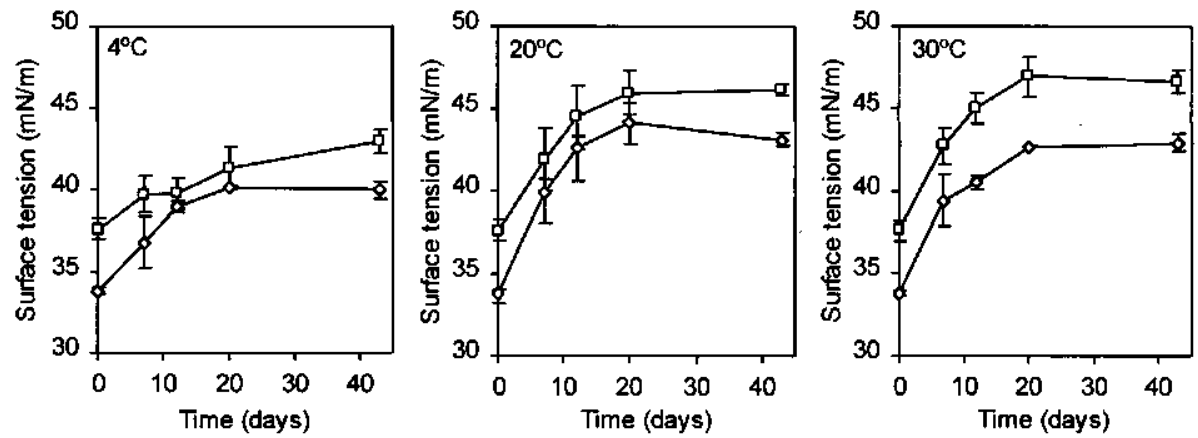

Fig. 3. The course of the surface tension during the anaerobic batch digestion of raw $(0)$ and paper-filtered $(\square)$ sewage in run 1 at temperature of 4,20 and $30^{\circ} \mathrm{C}$.

The initial surface tension of paper-filtered black water was higher than that for paper filtered domestic sewage (Fig. 4), probably due to the fact that hardly any detergents are added to black water. After 135 days batch digestion at 20 and $30^{\circ} \mathrm{C}$ the maximum surface tension of black water almost reached that of water. Part of the surfactants was retained during filtration as shown by the higher initial surface tension of paper-filtered as compared to raw sewage (Fig. 3), while that of membrane-filtered sewage is higher than that of paperfiltered sewage (Fig. 4). As the initial surface tension of the membrane-filtered sewage was still lower than that of water, some surfactants were remaining, even after 135 days batch digestion (Fig. 4). The surfactants, remaining after digestion, are however removed by a repeated membrane filtration prior to measurement (Fig. 4), which indicates that they are mainly adsorbed to particles produced during the digestion process.

The dependency of the surface tension upon dilution (Fig. 5) indicates that the surfactant concentration in paper-filtered sewage was lower than the CMC. 

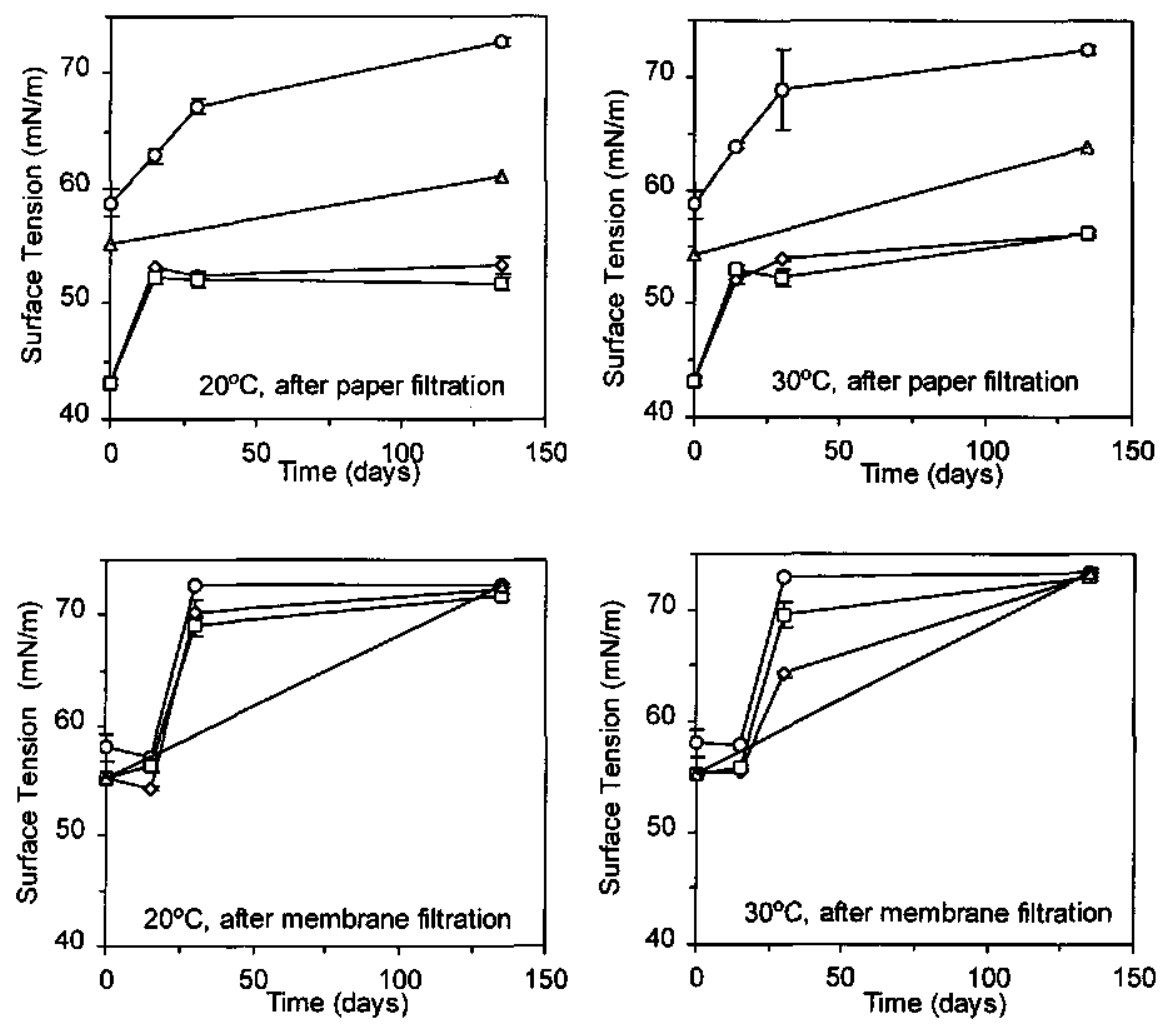

Fig. 4. The course of the surface tension during the anaerobic batch digestion of raw sewage $(0)$, paper-filtered sewage $(\square)$, membrane-filtered sewage $(\Delta)$ and black water $(O)$ in run 2 at temperature of 20 and $30^{\circ} \mathrm{C}$.

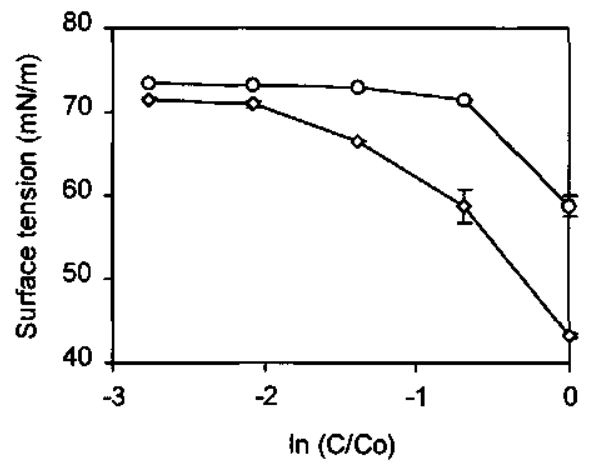

Fig. 5. Effect of dilution on the surface tension of domestic sewage $(0)$ and black water $(O)$ used in run 2. 


\section{Average radius}

Fig. 6 shows that the average initial radius of particles after paper or membrane-filtration of black water is much higher as compared to that of domestic sewage. Although the raw sewage was paper-filtered with a pore diameter of $4.4 \mu \mathrm{m}$, the average radius of the particles in paper-filtered sewage was only $188 \mathrm{~nm}$. Therefore, a large quantity of very small particles is present in domestic sewage. The latter is confirmed by the low average radius of $68 \mathrm{~nm}$ of the particles in membrane-filtered sewage.

A period of 135 days batch digestion of raw, paper-filtered and membrane-filtered sewage followed by paper or membrane filtration resulted in an increase of the average radius at both 20 and $30^{\circ} \mathrm{C}$. It is well known that hydrolysis causes a decrease of the wastewater substrate particles, while remaining substrate is overgrown with biomass (Sanders et al., 2000 ), which can result in an increase of the average radius of the particles.

The anaerobic digestion of membrane-filtered sewage produces colloidal particles. After 135 days of batch digestion at 20 and $30^{\circ} \mathrm{C}$, the $\mathrm{COD}_{\mathrm{col}}$ concentration in the membrane-filtered samples amounted to respectively 38 and $20 \mathrm{mg} \mathrm{l}^{-1}$. Methanogenesis of $\mathrm{COD}_{\mathrm{dis}}$ might therefore affect the removal of $\mathrm{COD}_{\mathrm{col}}$ in a continuous anaerobic reactor treating domestic sewage.
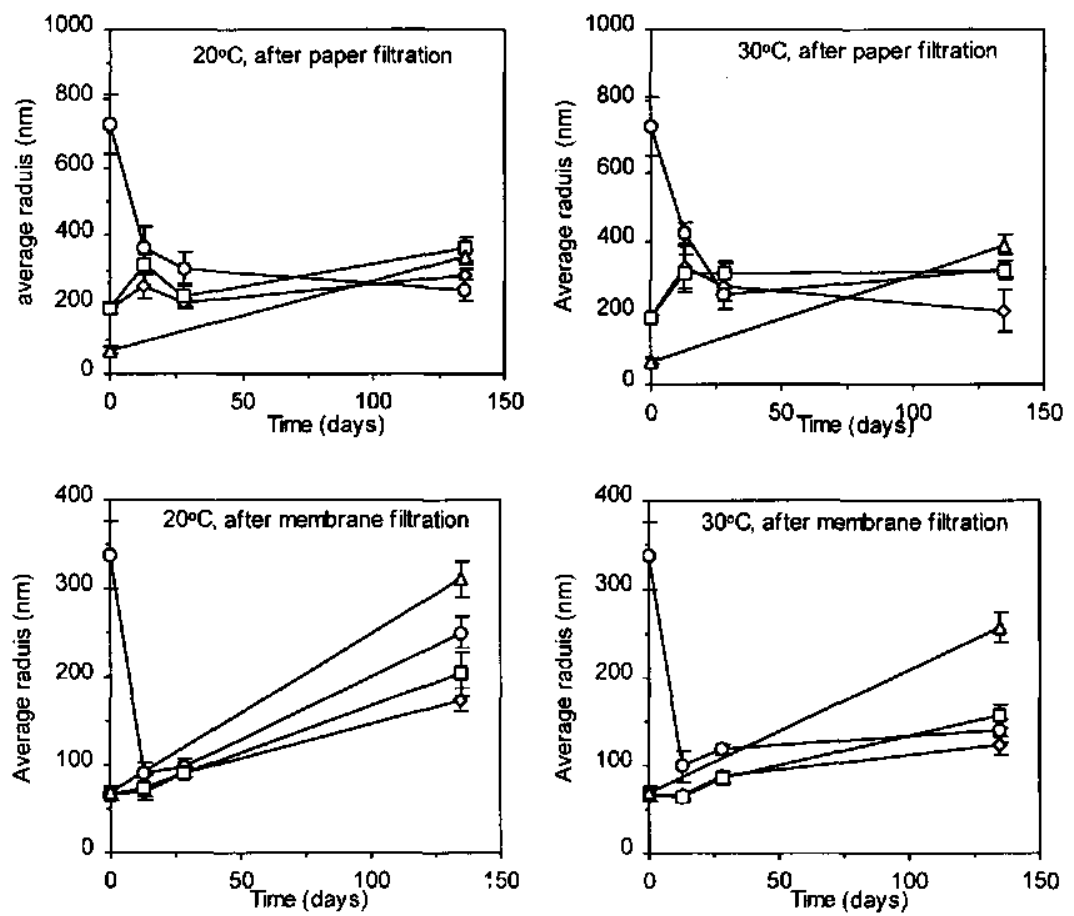

Fig. 6. The course of the average radius during the anaerobic batch digestion of raw sewage $(\diamond)$, paper-filtered sewage $(\square)$, membrane-filtered sewage $(\Delta)$ and black water $(O)$ in run 2 at temperature of 20 and $30^{\circ} \mathrm{C}$. 
Batch digestion of black water for 15-28 days followed by either paper or membrane filtration decreased the average radius of the particles at both 20 and $30^{\circ} \mathrm{C}$. However, after 135 days batch digestion, it almost remained unchanged for samples after paper filtration and increased for samples after membrane filtration. Therefore, in the first 15-28 days, the hydrolysis was higher than the entrapment of particles to the produced biomass.

\section{Zeta Potential}

Table 3 shows the assessed values of the zeta-potential in run 2. Anaerobic batch digestion for a period of 135 days, led to only a slight decrease in the negative zeta-potential for all wastewater samples. Thus during anaerobic digestion, the number of negative groups per unit area remains almost constant and electrostatic repulsion between the colloidal particles does not change significantly.

Table 3. Zeta-potential at constant ionic strength $(0.02 \mathrm{M} \mathrm{KCl})$ for raw and paper-filtered sewage and black water before and after anaerobic batch digestion in run 2 at temperatures of 20 and $30^{\circ} \mathrm{C}$. Standard deviations are presented in brackets.

\begin{tabular}{lcccc}
\hline Wastewater & Temperature & \multicolumn{3}{c}{ Zeta-potential (mV) } \\
\cline { 3 - 5 } & $\left({ }^{\circ} \mathrm{C}\right)$ & Initial & After 28 d & After 135 d \\
\hline Raw sewage & 20 & $-22.6(1.8)$ & $-22.5(0)$ & $-19.5(0.4)$ \\
& 30 & $-22.6(1.8)$ & $-22.3(0.3)$ & $-19.5(0.2)$ \\
Paper-filtered sewage & 20 & $-22.6(1.8)$ & $-22.4(0.1)$ & $-20.2(0.3)$ \\
& 30 & $-22.6(1.8)$ & $-23.1(0.1)$ & $-20.5(0.3)$ \\
Black water & 20 & $-24.8(0.8)$ & $-23.8(0.2)$ & $-19.9(0.1)$ \\
& 30 & $-24.8(0.8)$ & $-24.9(0.4)$ & $-20.1(2.6)$ \\
\hline
\end{tabular}

\section{General discussion and conclusions}

The high biodegradability of domestic sewage and black water reveals the potential of anaerobic treatment. Moreover a high methanogenesis of the colloidal fraction in domestic sewage $(86 \pm 3 \%)$ is achieved, showing that the low removal of $\mathrm{COD}_{\text {col }}$ in continuous highrate anaerobic reactors is due to low physical removal rather than biodegradability.

The development of the surface tension during batch digestion indicates a limited biodegradability of the present surfactants. An important part of the surfactants in sewage is formed by detergents, which are reported to have a low anaerobic biodegradability. The present results also show that part of the surfactants is not biodegraded during anaerobic batch digestion. Moreover, it is demonstrated that surfactants are partly connected to particles, both suspended and colloidal. The latter could affect the stability and therefore, low removal of colloidal particles in domestic sewage. Though colloidal particles were hydrolysed to a high degree, the average particle size increased due to growth of biomass. In continuous high-rate systems, the latter cannot be expected, as biodegradation can only take place after physical removal by the sludge bed. The zeta-potential of all particles is negative and hardly changes during digestion, showing that colloidal interactions were not affected by anaerobic digestion. As the anaerobic biomass also has a negative charge (Morgan et al., 1990), colloidal removal in continuous anaerobic systems treating domestic sewage can be expected to remain low, independent of the applied conditions. Improvement of the colloidal fraction and therewith conversion to $\mathrm{CH}_{4}$ gas, could be imposed by addition 
of coagulants, for destabilisation of the colloids. By pre-removal of the SS in a first anaerobic step, the costs of the use of coagulants in the second step could be reduced.

As hydrolysis of suspended particles produces more inert dissolved COD than hydrolysis of colloidal particles, the introduction of a first high-loaded anaerobic step for removal of SS could improve the dissolved effluent quality. The latter is also shown by Elmitwalli et al. (1999 a). The removal of SS from domestic sewage prior to methanogenesis can be achieved by either settling or treatment in a high-loaded anaerobic reactor (Zeeman et al., 1997; Elmitwalli et al., 1999 b).

\section{ACKNOWLEDGEMENTS}

We acknowledge the Egyptian Ministry of Higher Education for the scholarship given for the first author. We are grateful to A. J. van der Linde, R. G. Fokkink, B. Spee, W. F. Threels, R.E. Roersma, B. Willemsen, I. Gerrits, J. van der Laan and H. Donker for technical support.

\section{REFERENCES}

Boller M. (1993) Removal of organic matter by physico-chemical mechanisms in wastewater treatment plants. Water Sci. Technol. 27(11), 167-183.

Elmitwalli T. A., Zandvoort M., Zeeman G., Bruning H. and Lettinga G. (1999 a) Low temperature treatment of domestic sewage in upflow anaerobic sludge blanket and anaerobic hybrid reactors. Water Sci. Technol. 39(5), 177-185.

Elmitwalli T. A., Sklyar V., Zeeman G. and Lettinga G. (1999 b) Low temperature pretreatment of domestic sewage in anaerobic hybrid and anaerobic filter reactor. Proc. 4th. IAWQ Conference on Biofilm Reactors. 17-20 October 1999, New York, USA.

Gregory J. (1993) The role of colloid interactions in solid-liquid separation. Water Sci. Technol. 27(10), 1-17.

- Hoit M. S., Fox K. K., Burford M., Daniel M. and Buckland H. (1998) UK monitoring study on the removal of linear Alkylbenzene sulphonate in trickling filter type sewage treatment plants. Contribution to GREAT-ER projects \#2. The Sci. of the total Environ. 210/211, 255-269.

Jirka A. and Carter M. J. (1975) Micro semi-automated analysis of surface and waste waters for chemical oxygen demand. Analytical Chemistry 47, 1397-1401.

Last A. R. M. van der and Lettinga G. (1992) Anaerobic treatment of domestic sewage under moderate climatic (Dutch) conditions using upflow reactors at increased superficial velocities. Water Sci. Technol. 25(7), 167-178.

Levine A. D., Tchobanaglous G. and Asano T. (1985) Characterization of the size distribution of contaminants in wastewater: treatment and reuse implications. J. Water Pollut. Control Fed. 57(7), 805-816.

Nielsen P. H. and Harremoes P. (1995) Solids: Report of the discussion session. Water Sci. Technol. 32(8), 273-275.

Morgan J. W., Forster C. F. and Evison L. (1990) A comparative study of the nature of biopolymers extracted from anaerobic and activated sludge. Water Res. 24(6), 743750 . 
Mukerjee P. and Mysels K. J. (1971) Critical micelle concentration of aqueous surfactant systems. National Standard Reference Data System. U. S. Department of Commerce, Washington.

Rouse J. D., Sabatini D. A., Suflita J. M. and Harwell J. H. (1994) Influence of surfactants on microbial degradation of organic compounds. Critical Reviews in Environ. Sci. and Technol. 24(4), 325-370.

Sanders W. T. M., Zeeman G. and Lettinga G. (2000) Anaerobic hydrolysis kinetics of particulate substrate. Water Sci. Technol. 41(3), 17-24.

Wagener S. and Schink B. (1987) Anaerobic degradation of nonionic and anionic surfactants in enrichment cultures and fixed-bed reactors. Water Res. 21(5), 615-622.

Wang K. (1994). Integrated anaerobic and aerobic treatment of sewage. $\mathrm{Ph}$. D. thesis, Department of Environmental Technology, Wageningen University, The Netherlands.

Wang K., Zeeman G. and Lettinga G. (1995) Alteration in sewage characteristics upon aging. Water Sci. Technol. 31(7), 191-200.

Waters J. and Feijtel T. C. J. (1995) AIS/CESIO Environmental surfactant monitoring programme: Outcome of five national pilot studies on LAS. Chemosphere 30, 1939-1956.

Yoda M., Hattori M. and Miyaji Y. (1985) Treatment of municipal wastewater by anaerobic fluidized bed: behaviour of organic suspended solids in anaerobic treatment of sewage. Proc. Seminar/Workshop: Anaerobic Treatment of Sewage, Amherst, Mass., U.S.A., 161-197.

Zeeman G., Sanders W. T. M., Wang K. Y and Lettinga G. (1997) Anaerobic treatment of complex wastewater and waste activated sludge. Application of upflow anaerobic solid removal (UASR) reactor for the removal and pre-hydrolysis of suspended COD. Water Sci. Technol. 35(10), 121-128. 


\section{Chapter 3}

\section{THE ROLE OF FILTER MEDIA IN REMOVING SUSPENDED AND COLLOIDAL PARTICLES IN AN ANAEROBIC REACTOR TREATING DOMESTIC SEWAGE}

Published as:

Elmitwalli T. A., Dun M. van, Bruning H., Zeeman G. and Lettinga G. (2000) The role of filter media in removing suspended and colloidal particles in anaerobic reactor treating domestic sewage. Biores. Technol. 72(3), 235-242. 


\section{THE ROLE OF FILTER MEDIA IN REMOVING SUSPENDED AND COLLOIDAL PARTICLES IN AN ANAEROBIC REACTOR TREATING DOMESTIC SEWAGE}

\section{ABSTRACT}

A column packed with clean sheets of reticulated polyurethane foam was fed with either raw sewage, synthetic sewage or skimmed milk for a short time to evaluate the mechanism of physical entrapment and filtration of particles. The results revealed that clean media were effective in the removal of suspended COD $(>75 \%)$ even with HRT as low as $0.5 \mathrm{~h}$ or upflow velocity as high as $10 \mathrm{~m} / \mathrm{h}$. However, the removal of colloidal COD remained poor under all experimental conditions. The treatment of raw sewage and paper-filtered sewage in a fedbatch recirculation system under anaerobic conditions resulted in average removal efficiencies for colloidal COD of $63 \%$ and $81 \%$ respectively at a temperature of $24 \pm 1^{\circ} \mathrm{C}$. Therefore, the presence of an anaerobic biofilm and the removal of SS from the influent increased the removal efficiency of colloidal $\mathrm{COD}$ in the treatment of domestic sewage in an anaerobic polyurethane-foam filter.

\section{KEY WORDS}

Anaerobic treatment; domestic sewage; suspended solids; colloidal particles; polyurethane filter.

\section{INTRODUCTION}

Anaerobic digestion represents a very suitable method for treatment of not only soluble, lowstrength wastewaters but also partially-soluble, low-strength wastewaters such as domestic sewage (Haandel and Lettinga, 1994; Lettinga, 1996). Up till now, the anaerobic treatment of sewage could be considered as a pretreatment process and post treatment of the anaerobic effluent for removal of the remaining chemical oxygen demand (COD), nutrient and pathogens appeared to be mandatory in most situations, depending on the effluent standards (Mergaert et al., 1992; Lettinga et al., 1993; Sousa and Foresti, 1996). Wang (1994) treated domestic sewage in a two-step upflow anaerobic sludge blanket (UASB) system with hydraulic retention time (HRT) of $3 \mathrm{~h}$ for the first step. The results of his research showed that the first UASB reactor could be considered as an improved primary settler. In addition to the high removal efficiency for suspended solids (SS) by filtration, some hydrolysis, acidification and conversion to biogas occur in the first UASB reactor.

Most anaerobic treatment processes are relatively efficient in removing SS of domestic sewage (Jewell, 1985). The removal of dissolved matter can be increased by using sludge with a higher methanogenic activity, such as granular sludge, and by increasing the contact between wastewater and sludge by applying high upflow velocity $\left(\mathrm{V}_{\mathrm{up}}\right)$ as in the expanded granular-sludge bed (EGSB) reactor. The removal of colloidal particles has not to date been satisfactory. Wang (1994) found that the removal of colloidal particles was the rate-limiting step in a two step UASB+EGSB system treating domestic sewage at an HRT of $3+2 \mathrm{~h}$ under low-temperature conditions. He found average removal efficiencies for colloidal COD 
$\left(\mathrm{COD}_{\text {col }}\right)$ of $40 \%$ and $42 \%$ at temperatures of 17 and $12{ }^{\circ} \mathrm{C}$ respectively. Sayed and Fergala (1995) considered the 'entrapment' mechanism involved in removing solids by the sludge bed not sufficient to remove colloidal particles. Yoda et al. (1985) also reported that the colloidal particles in the influent were very difficult to remove and represented up to $60-70 \%$ COD of the effluent of an anaerobic fluidized bed (AFB) reactor.

Last and Lettinga (1992) and Wang (1994) treated presettled or pretreated domestic sewage in batch recirculation experiments with granular sludge at a temperature of $20^{\circ} \mathrm{C}$. The results are presented in Table 1 and show that the colloidal fraction was removed to any significant extent only when a long batch digestion time was applied. At a short batch digestion time of 24 hours, low colloidal removal efficiencies were achieved under both UASB and EGSB conditions.

Table 1. Removal of total COD, suspended COD, colloidal COD and dissolved COD under anaerobic conditions for presettled and pretreated domestic sewage in batch recirculation experiments with granular sludge at a temperature of $20^{\circ} \mathrm{C}$.

\begin{tabular}{|c|c|c|c|c|c|c|c|c|}
\hline \multirow[t]{2}{*}{ Sewage } & \multirow{2}{*}{$\begin{array}{c}\text { Recirculation } \\
\text { time (h) }\end{array}$} & \multirow{2}{*}{$\begin{array}{c}\mathrm{V}_{\mathrm{up}} \\
(\mathrm{m} / \mathrm{h})\end{array}$} & \multirow{2}{*}{$\begin{array}{c}\text { Initial COD } \\
(\mathrm{mg} /)\end{array}$} & \multicolumn{4}{|c|}{ COD removal (\%) } & \multirow[t]{2}{*}{ Reference } \\
\hline & & & & $\mathrm{COD}_{i}^{*}$ & $\mathrm{COD}_{\mathrm{ss}}$ & $\mathrm{COD}_{\mathrm{col}}$ & $\operatorname{COD}_{\mathrm{dis}}$ & \\
\hline \multicolumn{9}{|c|}{ Presettled sewage:- } \\
\hline & 144 & 1 & 421 & 65 & 84 & 72 & 44 & $\begin{array}{l}\text { Last and } \\
\text { Lettinga (1992) }\end{array}$ \\
\hline & 144 & 6 & 372 & 42 & 0 & 70 & 54 & $\begin{array}{l}\text { Last and } \\
\text { Lettinga (1992) }\end{array}$ \\
\hline \multicolumn{9}{|c|}{ Pretreated sewage:- } \\
\hline & 24 & 1 & 502 & 63 & 92 & 32 & 52 & Wang (1994) \\
\hline & 144 & 1 & 502 & 74 & 96 & 80 & 57 & Wang (1994) \\
\hline & 24 & 6 & 502 & 59 & 81 & 23 & 61 & Wang (1994) \\
\hline & 144 & 6 & 502 & 71 & 92 & 63 & 61 & Wang (1994) \\
\hline
\end{tabular}

Specific surface area, porosity, surface roughness, pore size and orientation of the packing material (PM) were found to play an important role in anaerobic filter (AF) reactor performance. High specific surface area and porosity, large pore size and rough surface for PM improved the performance of an AF reactor (Berg and Kennedy, 1981; Huysman et al., 1983; Young and Dahab, 1983; Young, 1991; Kennedy and Droste, 1991; Iwai and Kitao, 1994). Oriented and porous PM showed better performances than random and non-porous PM respectively (Young and Dahab, 1983; Huysman et al. 1983; Anderson et al., 1994). Huysman et al. (1983) mentioned that reticulated polyurethane foam (porous media) appeared an excellent colonisation matrix for an AF reactor. Reticulated polyurethane foam (RPF) has a high specific surface area which can reach up to $2400 \mathrm{~m}^{2} / \mathrm{m}^{3}$ and a high porosity of $97 \%$ (Huysman et al., 1983). The RPF is able to retain over $15 \mathrm{kgVS} / \mathrm{m}^{3}$ reactor volume in the attached form (Tilche and Vieira, 1991).

Miyahara and Noike (1994) studied the effect of AF media on SS removal and hydrolysis, by feeding the anaerobic reactor with a low strength synthetic wastewater $(550 \mathrm{mg} / 1 \mathrm{COD})$ 
containing cellulose as SS. They found that the effluent water quality was improved remarkably and the percentage of cellulose hydrolysis was promoted by packing the reactor. Miyahara et al. (1995) found that the number of suspended acidogenic bacteria in an AF reactor was higher than that of bacteria attached to the media. On the other hand, the number of attached methanogenic bacteria was higher than the number of suspended methanogenic bacteria.

The objective of the present research was to find the maximum achievable physical and biophysical removal efficiencies for suspended $\operatorname{COD}\left(\mathrm{COD}_{\mathrm{ss}}\right)$ and $\mathrm{COD}_{\mathrm{col}}$ during the treatment of domestic sewage in an AF reactor packed with vertical sheets of RPF.

\section{MATERIALS AND METHODS}

\section{Experimental configuration}

Fig. 1 shows a schematic diagram of the experimental set-up. The column used for the short run experiments and the reactor and container used for the fed-batch recirculation experiments were made of plexiglass and had an internal diameter of $8.25 \mathrm{~cm}$. The height of the column was $1 \mathrm{~m}$, while the heights of both reactor and container were $29 \mathrm{~cm}$. The PM used in both column and reactor was RPF sheets from Recticel, Buren, The Netherlands. Each sheet had knobs on one side, while the other side was flat. Table 2 shows the characteristics of the sheets according to Recticel. Four vertical sheets with a height of $90 \mathrm{~cm}$ each and one sheet of $34 \mathrm{~cm} \mathrm{x} 25 \mathrm{~cm}$ were used in the column and reactor respectively. The sheet in the reactor was moulded in a cylindrical shape where it occupied $25 \mathrm{~cm}$ of the reactor height. The upflow velocity in the reactor was $1 \mathrm{~m} / \mathrm{h}$ during all experimental runs in the fed-batch recirculation experiments, while it was varied in the short-run experiments.

Table 2. Characteristics of the RPF sheets.

\begin{tabular}{lcc}
\hline Parameter & Unit & Value \\
\hline Total sheet thickness & $\mathrm{mm}$ & 20 \\
Base thickness & $\mathrm{mm}$ & 10 \\
Knob thickness & $\mathrm{mm}$ & 10 \\
Specific surface area & $\mathrm{m}^{2} / \mathrm{m}^{3}$ & 500 \\
Density & $\mathrm{kg} / \mathrm{m}^{3}$ & $19-22$ \\
Number of pores & pore $/ \mathrm{inch}$ & $7-15$ \\
Pore size & $\mathrm{mm}$ & 2.5 \\
\hline
\end{tabular}

\section{Substrate}

During the fed-batch recirculation experiments and 20 runs of the short-run experiments, raw sewage was used as the basis of the feeds. The raw sewage used in the experiments was from the village of Bennekom, The Netherlands. The sewage was collected in a combined sewer system and was continuously supplied. The sewage was used either raw, presettled or paperfiltered $(4.4 \mu \mathrm{m})$. Table 3 shows the concentrations of the COD fractions for the sewage used in the experiment. 




(a)

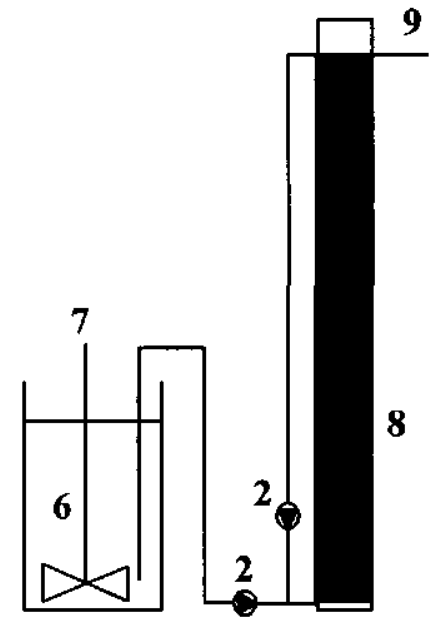

(b)

Fig. 1. Schematic diagram of the experimental set-up. (a), fed-batch recirculation experiment; (b), short-run experiment; 1, wastewater container; 2 , peristaltic pump; 3 , reactor; 4 , container for $\mathrm{NaOH}$ solution $(3 \%) ; 5$, to Marriott flask for measuring biogas; 6 , wastewater storage tank; 7 , mixer; 8 , column; 9 , effluent.

Table 3. Mean values of the COD fractions of the sewage used in the experiments.

Standard deviations are presented in brackets.

\begin{tabular}{lcccc}
\hline Sewage & \multicolumn{4}{c}{$\mathrm{COD}(\mathrm{mg} / \mathrm{l})$} \\
\cline { 2 - 5 } & $\mathrm{COD}_{\mathrm{t}}$ & $\mathrm{COD}_{\mathrm{ss}}$ & $\mathrm{COD}_{\text {col }}$ & $\mathrm{COD}_{\text {dis }}$ \\
\hline Raw & $772(293)$ & $426(251)$ & $133(66)$ & $213(62)$ \\
Presettled & $356(121)$ & $115(80)$ & $85(53)$ & $156(59)$ \\
Paper-filtered & $360(100)$ & - & $185(51)$ & $175(58)$ \\
\hline
\end{tabular}

During the short-run experiments, synthetic sewage, with and without nutrient, and skimmed milk were also used as influents. The synthetic sewage composition is described by Rensink (1974). The average total COD (COD $), \mathrm{COD}_{\mathrm{ss}}, \mathrm{COD}_{\mathrm{col}}$ and dissolved COD (COD dis $)$ for synthetic sewage were $595,377,75$ and $143 \mathrm{mg} / 1$ respectively. The $\mathrm{COD}_{\mathrm{ss}}, \mathrm{COD}_{\mathrm{col}}$ and $\mathrm{COD}_{\mathrm{dis}}$ of the skimmed milk were $3 \%, 35 \%$ and $62 \%$ of $\mathrm{COD}_{\mathrm{t}}$ respectively.

\section{Experimental set-up}

\section{Short-run experiments}

The aim of the experiments was to determine the physical removal of $\mathrm{COD}_{\mathrm{ss}}$ and $\mathrm{COD}_{\mathrm{col}}$ by clean media under conditions of different HRT's and upflow velocities. Each run started with clean media and to exclude the effect of biofilm formation the experimental period lasted for only 2.25 HRT's. The upflow velocities applied at a HRT of $2 \mathrm{~h}$ were varied by recirculating 
the effluent. For the treatment of domestic sewage at HRT's of 4 and $8 \mathrm{~h}$, the upflow velocity was adjusted at $0.5 \mathrm{~m} / \mathrm{h}$ by recirculating the effluent. The experiments were performed at an ambient temperature of $20 \pm 2^{\circ} \mathrm{C}$.

To study the effect of the absence of $\mathrm{COD}_{\mathrm{ss}}$ on $\mathrm{COD}_{\mathrm{col}}$ removal, the experiment was carried out with skimmed-milk feed, while to investigate the effect of nutrient a synthetic sewage feed supplemented with nutrient was used. Samples from the influent and effluent were taken during the last 0.25 HRT of each run. A total of 31 runs were carried out. Table 4 shows the operational conditions of the experiments.

Table 4. Operational conditions of the short-run experiments.

\begin{tabular}{|c|c|c|c|c|c|c|c|c|}
\hline & \multicolumn{4}{|c|}{ No. of runs } & \multicolumn{4}{|c|}{ No. of runs } \\
\hline $\begin{array}{l}0.5 \mathrm{~h} \\
\text { HRT }\end{array}$ & $\begin{array}{c}1 \mathrm{~h} \\
\text { HRT }\end{array}$ & $\begin{array}{c}2 \mathrm{~h} \\
\mathrm{HRT}\end{array}$ & $\begin{array}{c}4 \mathrm{~h} \\
\text { HRT } \\
\end{array}$ & $\begin{array}{c}8 \mathrm{~h} \\
\text { HRT }\end{array}$ & $\begin{array}{c}1 \mathrm{~m} / \mathrm{h} \\
\mathrm{V}_{\text {up }}\end{array}$ & $\begin{array}{c}2 \mathrm{~m} / \mathrm{h} \\
\mathrm{V}_{\mathrm{up}}\end{array}$ & $\begin{array}{c}6 \mathrm{~m} / \mathrm{h} \\
\mathrm{V}_{\text {up }}\end{array}$ & $\begin{array}{c}10 \mathrm{~m} / \mathrm{h} \\
\mathrm{V}_{\mathrm{up}}\end{array}$ \\
\hline \multicolumn{9}{|l|}{ Raw sewage } \\
\hline 2 & 2 & 2 & 2 & 2 & 2 & 2 & 2 & 2 \\
\hline \multicolumn{9}{|c|}{ Synthetic sewage without nutrients } \\
\hline- & - & 2 & 2 & - & 2 & 2 & - & - \\
\hline \multicolumn{9}{|c|}{ Synthetic sewage with nutrients } \\
\hline Skimmed milk & - & 2 & - & - & - & - & - & - \\
\hline- & - & 1 & - & 1 & - & 1 & - & - \\
\hline
\end{tabular}

Fed-batch recirculation experiments

The experiments were carried out in three separate runs and the differences between the three runs are shown in Table 5. The apparatus of the experiments was in a temperature controlled room at $24 \pm 1^{\circ} \mathrm{C}$ for run 1 and run 2 and at $8.5 \pm 0.5^{\circ} \mathrm{C}$ for run 3 . Each run was started with clean PM and both the reactor and the container were filled with fresh sewage (feed 1). After one day of recirculation, the wastewater in the container (effluent of feed 1) was completely removed and replaced by fresh sewage. Thereafter, the wastewaters in both container and reactor were again recirculated for 1 day followed by the same procedure of emptying and filling. The influent COD for each feed, from feed 2 till feed 24, was calculated by dividing wastewater COD $(\mathrm{mg})$ in both reactor and container (fresh sewage) before starting recirculation by the total wastewater volume in both reactor and container (litre). As one recirculation of the wastewater through the system needed only $0.58 \mathrm{~h}$, the characteristics of the wastewater in the container at the end of each feed were assumed to be similar to those in the reactor. Therefore, the wastewater in the container at the end of each feed was considered to represent the effluent of each feed.

Table 5. Operational conditions of the fed-batch recirculation experiments.

\begin{tabular}{llcc}
\hline Run & Type of sewage & No. of feeds & Temperature $\left({ }^{\circ} \mathrm{C}\right)$ \\
\hline 1 & Raw & 24 & $24 \pm 1$ \\
2 & Raw & 7 & $24 \pm 1$ \\
& Presettled & 6 & $24 \pm 1$ \\
& paper-filtered & 11 & $24 \pm 1$ \\
3 & Raw & 24 & $8.5 \pm 0.5$ \\
\hline
\end{tabular}




\section{Analytical methods}

COD was analyzed using the micro-method described by Jirka and Carter (1975). Raw samples were used for $\mathrm{COD}_{t}, 4.4 \mu \mathrm{m}$ folded paper-filtered (Schleicher and Schuell 5951/2, Germany) samples for $\mathrm{COD}_{\mathrm{f}}$ and $0.45 \mu \mathrm{m}$ membrane filtered (Schleicher and Schuell ME 25, Germany) samples for $\mathrm{COD}_{\text {dis }}$. All measurements were determined in duplicate. $\mathrm{COD}_{\mathrm{t}}$ was divided into $\mathrm{COD}_{\mathrm{ss}}, \mathrm{COD}_{\mathrm{col}}$ and $\mathrm{COD}_{\text {dis }}$. The $\mathrm{COD}_{\mathrm{ss}}$ and $\mathrm{COD}_{\mathrm{col}}$ were calculated by the differences between $\mathrm{COD}_{\mathrm{t}}$ and $\mathrm{COD}_{\mathrm{f}}, \mathrm{COD}_{\mathrm{f}}$ and $\mathrm{COD}_{\mathrm{dis}}$ respectively.

\section{Statistical analysis}

Statistical Comparison between the performances of the reactors was done according to Snedecor and Cochran (1980). The performance of each run was assumed to be independent with different variance.

\section{Hydrolysis calculations}

The hydrolysis of particulate COD was calculated based on the influent particulate COD or on the removed particulate COD according to equations 1 and 2.

$$
\begin{aligned}
& H_{1}=100\left(\frac{C H_{+} \text {as } C O D+\text { effluent } C O D_{\text {dis }}-\text { influent } C O D_{d i s}}{\text { influent } C O D_{r}-\text { influent } C O D_{d i s}}\right) \\
& H_{\text {rew }}=100\left(\frac{\mathrm{CH}_{4} \text { as } C O D+\text { effluent } C O D_{\text {dis }}-\text { influent } C O D_{\text {dis }}}{\left(\text { influent } C O D_{1}-\text { influent } C O D_{\text {dis }}\right)-\left(\text { effluent } C O D_{1}-\text { effluent } C O D_{\text {dis }}\right)}\right)
\end{aligned}
$$

Where

$H_{t} \quad=$ percentage of hydrolysis based on the influent particulate COD (\%)

$H_{\text {rem }}=$ percentage of hydrolysis based on the removed particulate COD $(\%)$

\section{RESULTS AND DISCUSSION}

\section{Short-run experiments}

Table 6 shows the operational results of the short run experiments with synthetic sewage, with and without nutrient, and skimmed milk. The results indicated that the clean media were effective in removing $\mathrm{COD}_{\mathrm{ss}}$, while $\mathrm{COD}_{\text {col }}$ removal was poor. Increasing the HRT from $2 \mathrm{~h}$ to $4 \mathrm{~h}$ and decreasing the upflow velocity from $2 \mathrm{~m} / \mathrm{h}$ to $0.5 \mathrm{~m} / \mathrm{h}$ hardly affected the removal of either $\mathrm{COD}_{\mathrm{ss}}$ or $\mathrm{COD}_{\mathrm{col}}$. The operational results with skimmed milk indicated that the absence of SS did not improve the physical removal of $\mathrm{COD}_{\text {col }}$. The addition of nutrient to synthetic sewage improved the $\mathrm{COD}_{\text {col }}$ removal but removal efficiency remained low.

The results of the experiment with domestic sewage are shown in Fig. 2 . The clean media were effective in the removal of $\mathrm{COD}_{\mathrm{ss}}$ by physical entrapment and filtration even with HRT as low as $0.5 \mathrm{~h}$ or upflow velocity as high as $10 \mathrm{~m} / \mathrm{h}$, while the maximum removal of $\mathrm{COD}_{\text {col }}$ was only $21 \%$. $C O D_{t}$ removal efficiency increased with increasing influent $\mathrm{COD}_{\mathrm{ss}} / \mathrm{COD}_{\mathrm{t}}$ ratio. 
Chapter 3

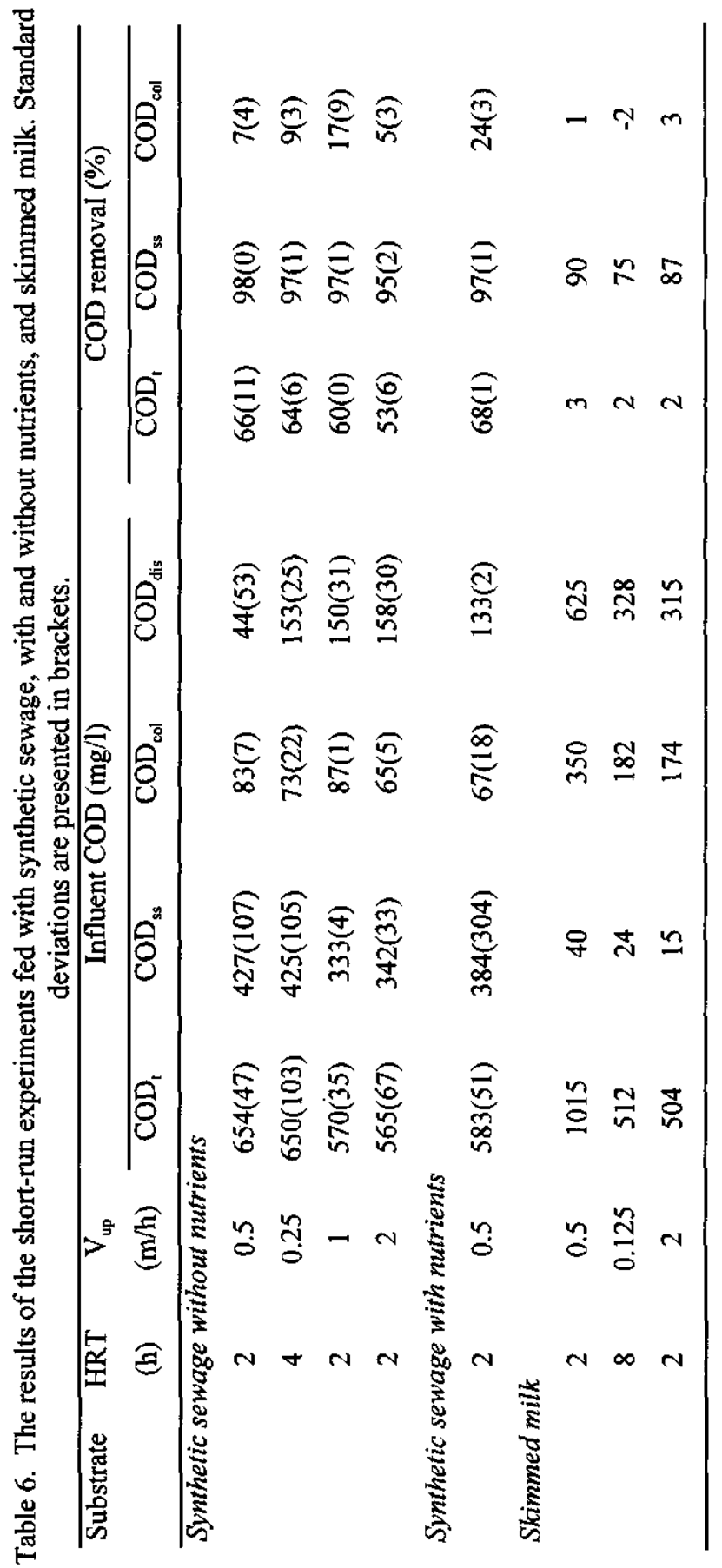



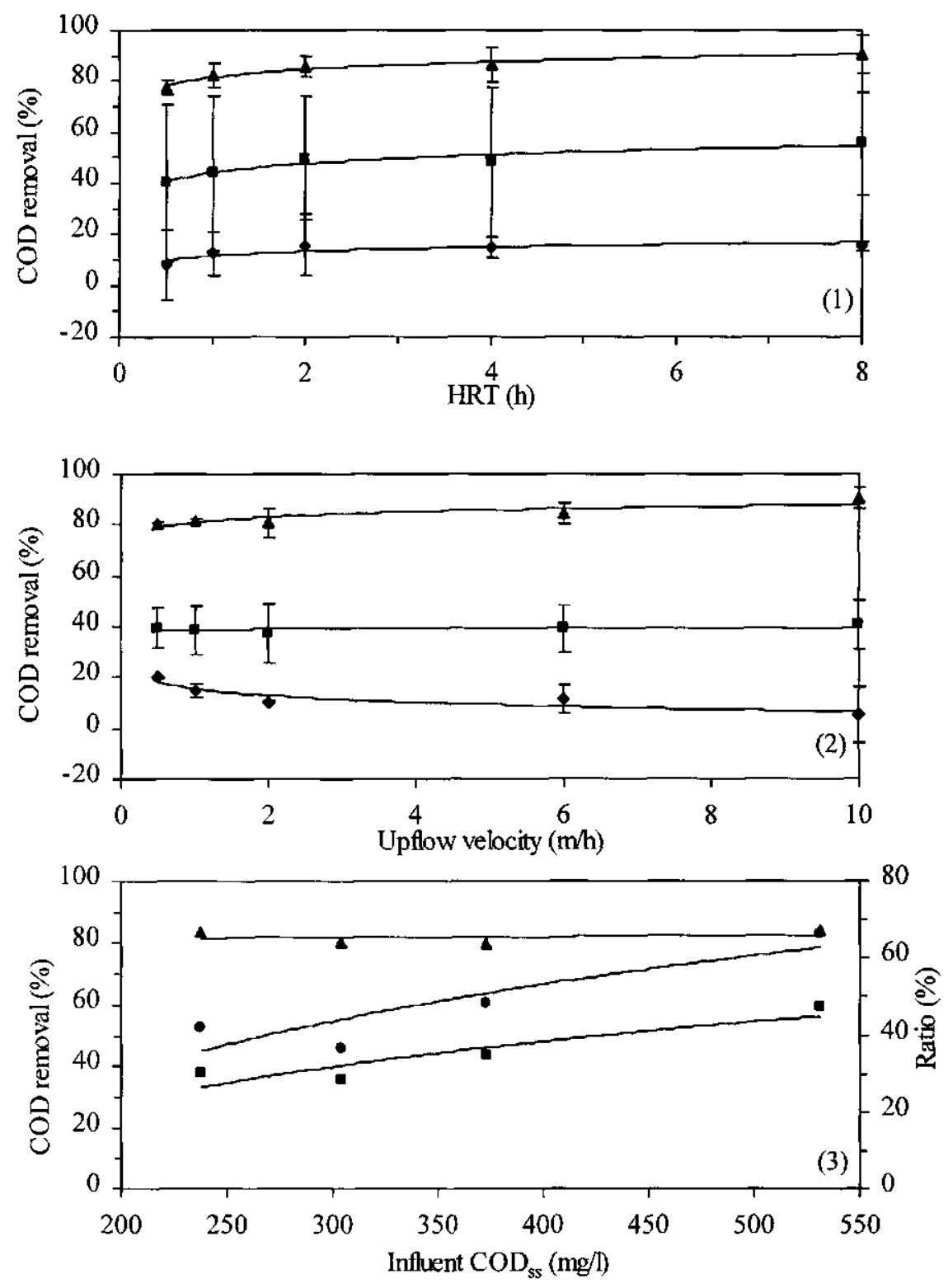

Fig. 2. The effect of HRT, upflow velocity and influent $\mathrm{COD}_{\mathrm{ss}}$ concentration on the COD removal in the short-run experiments with raw sewage. (1) effect of HRT with upflow velocity of $0.5 \mathrm{~m} / \mathrm{h}$ (except for HRT's of 0.5 and $1 \mathrm{~h}$ which had upflow velocities of 2 and 1 $\mathrm{m} / \mathrm{h}$ respectively) and influent $\mathrm{COD}_{t}$ concentrations of 570 and $770 \mathrm{mg} / \mathrm{l} ;$ (2), effect of upflow velocity with HRT of $2 \mathrm{~h}$ and influent $\mathrm{COD}_{\mathrm{t}}$ concentration of 600 and $800 \mathrm{mg} / \mathrm{l}$; (3), effect of influent $\mathrm{COD}_{\mathrm{ss}}$ concentration with HRT of $2 \mathrm{~h}$ and upflow velocity of $0.5 \mathrm{~m} / \mathrm{h}$. ( $), \mathrm{COD}_{\mathrm{t}}$; $(\boldsymbol{\Delta}), \mathrm{COD}_{\mathrm{ss}} ;(\diamond) \mathrm{COD}_{\mathrm{col}} ;(\boldsymbol{\Theta})$, ratio [(influent $\mathrm{COD}_{\mathrm{ss}} /$ influent $\left.\mathrm{COD}_{\mathrm{t}}\right)^{*} 100$ ]. 


\section{Fed-batch recirculation experiments}

\section{Run 1}

The results of run 1 , with raw sewage at temperatures of $24 \pm 1^{\circ} \mathrm{C}$, are shown in Fig. (3.1) and Table 7. The relatively constant values for the removal efficiencies of $\mathrm{COD}_{\mathrm{ss}}$ and $\mathrm{COD}_{\mathrm{col}}$ indicate that 'steady state' was certainly achieved from the $14^{\text {th }}$ feeding. A significant increase at a $1 \%$ level in removal efficiency of both $\mathrm{COD}_{\mathrm{ss}}$ and $\mathrm{COD}_{\mathrm{col}}$ was shown between the start-up and the 'steady state' period. So, the attachment of biomass and/or entrapment of solids increased the removal efficiencies of both $\mathrm{COD}_{\mathrm{ss}}$ and $\mathrm{COD}_{\mathrm{col}}$. The removal of $\mathrm{COD}_{\mathrm{col}}$ was lower during the start-up period as compared to 'steady state' showing that the presence of a biofilm was playing a part in the removal of smaller particles.

The removal efficiencies of $\mathrm{COD}_{\mathrm{ss}}$ and $\mathrm{COD}$ col in run 1 were higher than those found by Last and Lettinga (1992) and Wang (1994) after $24 \mathrm{~h}$ batch recirculation with a $\mathrm{V}_{\mathrm{up}}$ of $1 \mathrm{~m} / \mathrm{h}$ (Table 1). The higher removal of $\mathrm{COD}_{\mathrm{ss}}$ and $\mathrm{COD}_{\mathrm{col}}$ in the reactor packed with RPF sheets compared to that in the reactor with granular sludge indicated that the entrapment and filtration mechanism was better in the packed reactor.

\section{Run 2}

The results of run 2 are shown in Fig. (3.2) and Table 7. The results of run 1 suggest that the first period of 13 feedings with raw sewage and presettled sewage could be considered as the start-up phase for the period during which the feed was paper-filtered sewage. The average $\mathrm{COD}_{\text {col }}$ removal efficiency increased from $63 \%$ for the treatment of raw sewage at 'steady state' to $81 \%$ for the treatment of paper-filtered sewage at 'steady state'. The difference was significant at a $0.5 \%$ level. The distinctly lower removal of $\mathrm{COD}_{\text {col }}$ when treating raw sewage was caused by production of $\mathrm{COD}_{\text {col }}$ from $\mathrm{COD}_{\mathrm{ss}}$.

\section{Run 3}

Fig. (3.3) and Table 7 show the results of run 3 where raw sewage was treated under lower temperature conditions. In this case, the first 13 feedings were considered to represent the start-up phase. Compared to the higher temperature, the removal of $\mathrm{COD}_{\mathrm{ss}}$ significantly (at a $0.1 \%$ level) decreased from $95 \%$ to $77 \%$. Hardly any removal of $\mathrm{COD}_{\text {col }}$ was found under these low temperature conditions, indicating that the removal of colloidal particles depended on biological processes.

\section{Methane production and hydrolysis of particulate COD}

Table 8 shows the total (released +dissolved) methane production and hydrolysis of particulate COD at 'steady state' for run 1 and run 2. During the fed-batch treatment of raw sewage at a temperature of $8.5 \pm 0.5^{\circ} \mathrm{C}$ no methane was released.

The fluctuation of the domestic sewage concentration caused high standard deviations for the conversion and hydrolysis. So, there was no significant difference in the conversion and hydrolysis between the treatment of raw sewage and the treatment of paper-filtered sewage at temperatures of $24 \pm 1^{\circ} \mathrm{C}$. However, the results indicated that the conversion and hydrolysis of colloidal particles were at least similar to the conversion and hydrolysis of suspended particles. 

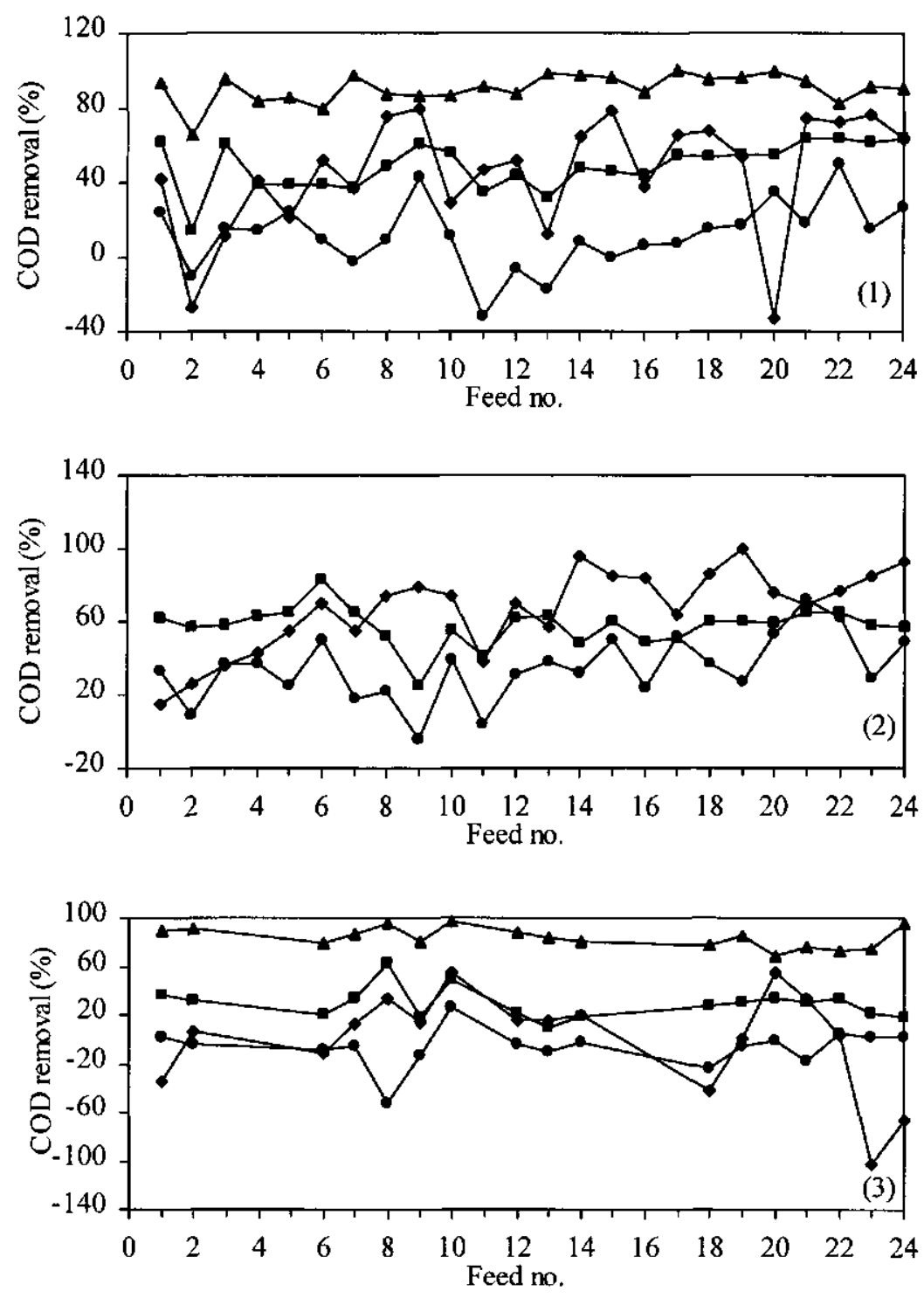

Fig. 3. COD removal efficiencies in the fed-batch recirculation experiments during the treatment of raw, paper-filtered and raw sewage at different temperatures. (1), raw sewage at $24 \pm 1^{\circ} \mathrm{C} ;(2)$, paper-filtered sewage at $24 \pm 1^{\circ} \mathrm{C} ;(3)$, raw sewage at $8.5 \pm 0.5^{\circ} \mathrm{C}$. (更), $\mathrm{COD}_{i} ;(\boldsymbol{\Delta})$, $\mathrm{COD}_{\mathrm{ss}} ;(\bullet) \mathrm{COD}_{\mathrm{col}} ;(\bullet), \mathrm{COD}_{\mathrm{dis}}$. 


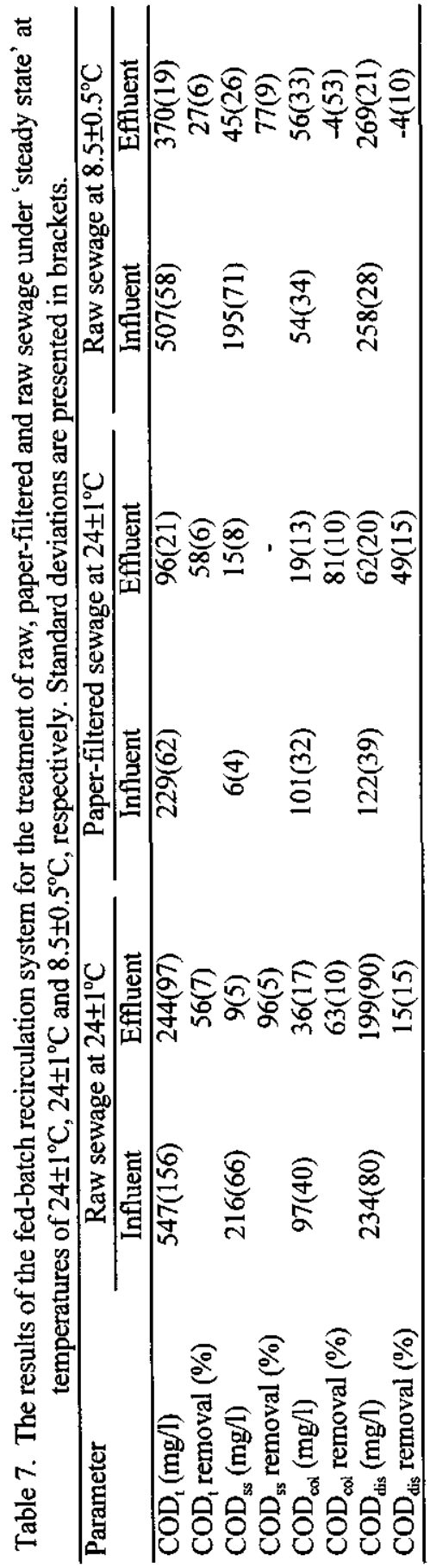


Table 8. Total methane production and hydrolysis of particulate COD at 'steady state' conditions during the fed-batch treatment of raw sewage and paper-filtered sewage at temperature of $24 \pm 1{ }^{\circ} \mathrm{C}$. Standard deviations are presented in brackets.

\begin{tabular}{lcc}
\hline Parameter & Raw sewage & Paper-filtered sewage \\
\hline $\mathrm{CH}_{4}$-COD/COD added (\%) & $30.2(4.7)$ & $35.6(3.1)$ \\
$\mathrm{CH}_{4}$-COD/COD removed (\%) & $44.6(8.4)$ & $61.8(8.3)$ \\
$\mathrm{M}^{3} \mathrm{CH}_{4}$ (STP)/kg COD removed & $0.16(0.03)$ & $0.22(0.03)$ \\
$\mathrm{H}_{\mathrm{t}}(\%)$ & $35.1(10.3)$ & $32.3(10.5)$ \\
$\mathrm{H}_{\text {rem }}(\%)$ & $30.8(7.1)$ & $43.2(14.3)$ \\
\hline
\end{tabular}

\section{General discussion}

The results of the short-run and the fed-batch recirculation experiments demonstrate that the RPF medium was effective in removing SS from raw sewage. The short-run experiments showed that more than $75 \%$ of $\mathrm{COD}_{\mathrm{ss}}$ could be removed even with $\mathrm{HRT}$ as low as $0.5 \mathrm{~h}$ or upflow velocity as high as $10 \mathrm{~m} / \mathrm{h}$. The fed-batch recirculation experiments showed that at 'steady state' $96 \%$ and $77 \%$ of the $\mathrm{COD}_{\mathrm{ss}}$ could be removed from raw sewage at temperatures of $24 \pm 1^{\circ} \mathrm{C}$ and $8.5 \pm 0.5^{\circ} \mathrm{C}$, respectively. The removal of $\mathrm{COD}_{\mathrm{ss}}$ at 'steady state' in the fed-batch recirculation experiments treating raw sewage at temperatures of $24 \pm 1^{\circ} \mathrm{C}$ was significantly better than that found during the start-up period. At low temperature with raw sewage, a lower $\mathrm{COD}_{\mathrm{ss}}$ removal was achieved. Also, in the short-run experiments a lower $\mathrm{COD}_{\mathrm{ss}}$ removal was shown. But at all applied conditions the removal of $\mathrm{COD}_{\mathrm{ss}}$ could be considered high $(>75 \%)$. The removal of $\mathrm{COD}_{\mathrm{ss}}$ in the RPF packed reactor could be mainly attributed to physical entrapment, although the presence of a biofilm on the RPF improved $\mathrm{COD}_{\mathrm{ss}}$ removal.

For colloidal particles, the removal depended on the presence of a biofilm and the process temperature. The removal of $\mathrm{COD}_{\text {col }}$ from raw sewage was $63 \%$ during 'steady state' in the fed-batch recirculation experiment at a temperature of $24 \pm 1^{\circ} \mathrm{C}$, while it was only $41 \%$ in the initial phase of the experiment and it was minus $4 \%$ at 'steady state' at a temperature of $8.5 \pm 0.5^{\circ} \mathrm{C}$. The maximum value found in the short-run experiments was $21 \%$.

Sprouse and Rittmann (1991), working with an AFB system packed with granular activated carbon (GAC), found that a better removal efficiency for both suspended and colloidal particles was achieved in a column where the GAC was covered with an anaerobic biofilm compared to a GAC medium coated with polymer. Based on these findings, they suggested that the anaerobic biofilm on the medium creates more favourable conditions for organic matter capture. It is well known that many living microorganisms have a flocculent growth habit and produce extracellular polymers, usually polysaccharides, polypeptides or peptidoglycans, which enhance biosorption of particles (Dugan, 1987). The growth of biomass is much more strongly affected by temperature than the physical adsorption (Iwai and Kitao, 1994), but when the temperature drops, the production of extracellular polymers from biomass will also decrease (Unz, 1987). The observed significantly lower removal of $\mathrm{COD}_{\mathrm{ss}}$ and $\mathrm{COD}_{\mathrm{col}}$ at temperature of $8.5 \pm 0.5^{\circ} \mathrm{C}$ compared to that at $24 \pm 1^{\circ} \mathrm{C}$ might, therefore, be caused by the decrease in conversion and/or biosorption of particles. 
The primary sedimentation tank, the most popular pretreatment process so far, provides distinctly lower removal efficiencies for COD and SS than the UASB reactor (Wang, 1994). Both hydrolysis and acidification can occur in these systems depending on the temperature and the sludge residence time. The RPF packed upflow reactor, investigated here, provides a higher capacity for removing $\mathrm{COD}_{\mathrm{ss}}$ than the UASB reactor. Wang (1994) found average removal efficiencies for $\mathrm{COD}_{\mathrm{ss}}$ of $65 \%$ and $44 \%$ in a UASB reactor operated at an HRT of 3 $\mathrm{h}$, at temperatures of 17 and $12^{\circ} \mathrm{C}$, respectively. Clogging of the filter media represents the main drawback of AF reactors. According to our own investigation (Elmitwalli et al., 1999), clogging could be avoided by orienting the RPF sheets with knobs vertically in the anaerobic reactor. Even when the media were oriented vertically without any spacing no clogging occurred after an operational period of about 100 days. Therefore, the use of a high-loaded AF reactor packed with vertical sheets of RPF represents an effective system for the pretreatment of raw sewage.

By applying an AF reactor as the first step of a two-step anaerobic reactor system, the major part of the $\mathrm{COD}_{\mathrm{ss}}$, and a part of $\mathrm{COD}$ col and $\mathrm{COD}_{\text {dis }}$, will be removed in the first reactor, while the remaining $C O D_{\text {col }}$ and $C O D_{\text {dis }}$ can be eliminated in the second anaerobic reactor. However, when using an EGSB or UASB reactor as the second stage, the removal of $\mathrm{COD}_{\text {col }}$ may remain limited (Last and Lettinga, 1992; Wang, 1994). Based on the results of the fed-batch recirculation experiments fed with paper-filtered sewage, addition of RPF vertical sheets in the upper part of a second UASB or EGSB reactor will improve the $\mathrm{COD}_{\text {col }}$ removal.

\section{CONCLUSIONS}

Clean RPF sheets have the capacity to remove the main part of $\operatorname{COD}_{\mathrm{ss}}(>75 \%)$ from raw sewage by a mechanism of physical entrapment and filtration, even with HRT as low as $0.5 \mathrm{~h}$ or $V_{\text {up }}$ as high as $10 \mathrm{~m} / \mathrm{h}$, but are not efficient in removing $\mathrm{COD}_{\text {col }}$.

An $\mathrm{AF}$ reactor equipped with RPF sheets and operated in a fed-batch recirculation mode at 1 day $\mathrm{HRT}$, is effective in removing $\mathrm{SS}$ from raw sewage, with average $\mathrm{COD}_{\mathrm{ss}}$ removal efficiencies of $96 \%$ and $76 \%$ at $24 \pm 11^{\circ} \mathrm{C}$ and $8.5 \pm 0.5^{\circ} \mathrm{C}$, respectively.

With paper-filtered sewage, the fed-batch recirculation system at 1 day HRT gave an average removal efficiency for $\mathrm{COD}_{\text {col }}$ of $81 \%$ at $24 \pm 1^{\circ} \mathrm{C}$, while it was $63 \%$ for raw sewage. The significantly higher removal efficiency for $\mathrm{COD}_{\mathrm{col}}$ with paper-filtered sewage was caused by production of $\mathrm{COD}_{\mathrm{col}}$ from $\mathrm{COD}_{\mathrm{ss}}$.

For raw sewage under conditions of fed-batch recirculation at 1 day HRT, the system gave a $\mathrm{COD}_{\mathrm{col}}$ removal efficiency of minus $4 \%$ at $8.5 \pm 0.5^{\circ} \mathrm{C}$, while it was $63 \%$ at $24 \pm 1^{\circ} \mathrm{C}$. The poor removal efficiency for $\mathrm{COD}_{\text {col }}$ at these low temperature conditions indicates that the removal of colloids depends on biological processes, bioconversion and/or biosorption.

\section{ACKNOWLEDGEMENTS}

We acknowledge the Egyptian Ministry of Higher Education for the scholarship given for the first author. We are grateful to Recticel, Buren, The Netherlands for providing the polyurethane foam sheet. We also are grateful to: W. Sanders, R.E. Roersma, B. Willemsen, 
D. van Doorn I. Gerrits and J. van der Laan for technical support.

\section{REFERENCES}

Anderson G. K., Kasapgil B. and Ince O. (1994) Comparison of porous and non-porous media in upflow anaerobic filters when treating dairy wastewater. Water Res., 28, 1619-1624.

Berg L. van den and Kennedy K. J. (1983) Dairy waste treatment with anaerobic stationary fixed film reactors. Water Sci. Technol, 15(8/9), 359-368.

Dugan P.R. (1987) The function of microbial polysaccharides in bioflocculation and biosorption of mineral ions. Proc. Flocculation in Biotechnology and Separation Systems, ed. Y.A. Attia, Elsevier Science Publishers B.V., The Netherlands, 337-350.

Elmitwalli T.A., Zandvoort M., Zeeman G., Bruning H. and Lettinga G. (1999) Low temperature treatment of domestic sewage in upflow anaerobic sludge blanket and anaerobic hybrid reactors. Water Sci. Technol., 39(5), 177-185.

Haandel A. C. van and Lettinga G. (1994) Anaerobic sewage treatment. John Wiley and Sons Ltd, Chichester, UK.

Huysman P., Meenen P. van, Assche P. van and Verstraete W. (1983) Factors affecting the colonization of non porous and porous packing materials in model upflow methane reactors. Biotechnol. Lett., 5(9), 643-648.

Iwai S. and Kitao T. (1994) Wastewater treatment with microbial films. Technomic Publishing Company Inc., USA.

Jewell W. J. (1985) The development of anaerobic wastewater treatment. Proc. Seminar/Workshop: Anaerobic Treatment of Sewage, ed Switzenbaum, Amherst, Mass., 1754.

Jirka A. and Carter M. J. (1975) Micro Semi-automated Analysis of Surface and Waste Waters for Chemical Oxygen Demand. Analytical Chemistry, 47, 1397-1401.

Kennedy K. J. and Droste R. L. (1991) Anaerobic wastewater treatment in downflow stationary fixed film reactors. Water Sci. Technol, 24(8), 157-177.

Last A. R. M. van der and Lettinga G. (1992) Anaerobic treatment of domestic sewage under moderate climatic (Dutch) conditions using upflow reactors at increased superficial velocities. Water Sci. Technol., 25(7), 167-178.

Lettinga G., Man A. W. A. de, Last A. R. M. van der, Wiegant W., Knippenberg K. van, Frijns J. and Buuren J. C. L. van (1993) Anaerobic treatment of domestic sewage and wastewater. Water Sci. Technol., 27(9), 67-73.

Lettinga G. (1996) Sustainable integrated biological wastewater treatment. Water Sci. Technol., 33(3), 85-98.

Mergaert K., Vanderhaegen B. and Verstraete W (1992) Application and trends of anaerobic pre-treatment of municipal wastewater. Water Res., 26, 1025-1033.

Miyahara T. and Noike T. (1994) Behaviour of suspended solids and anaerobic bacteria in an anaerobic fixed bed reactor. Water Sci. Technol., 30(12), 75-86.

Miyahara T. Takano M. and Noike T. (1995) Role of filter media in an anaerobic fixed bed reactor. Water Sci. Technol., 31(9), 137-144.

Rensink J. H. (1974) New approach to preventing bulking sludge. J. Water Poll. Control Fed, 46(8), 1888-1894.

Sayed S. K. I. and Fergala M. A. A. (1995) Two-stage UASB concept for treatment of domestic sewage including sludge stabilization process. Wat. Sci. Technol, 32(11), 5563.

Snedecor G.W. and Cochran W.G. (1980) Statistical methods. The lowa state university press, Ames, Iowa, USA. 
Sousa J. T. de and Foresti E. (1996) Domestic sewage treatment in an upflow anaerobic sludge blanket-sequencing batch reactor system. Water Sci. Technol, 33(3), 73-84.

Sprouse G. and Rittmann B.E. (1991) Colloidal removal in fluidized-bed biofilm reactor. $J$. Environ. Eng., 116(2), 314-329

Tilche A. and Vieira M. M. (1991) Discussion report on reactor design of anaerobic filters and sludge bed reactors. Water Sci. Technol., 24 (8), 193-206.

Unz R. F. (1987) Aspects of bioflocculation: an overview. Proc. Flocculation in Biotechnology and Separation Systems, ed. Y.A. Attia, Elsevier Science Publishers B.V., The Netherlands, 351-368.

Wang K. (1994) Integrated anaerobic and aerobic treatment of sewage. Ph. D. thesis, Department of Environmental Technology, Wageningen University, The Netherlands.

Yoda M., Hattori M. and Miyaji Y. (1985) Treatment of municipal wastewater by anaerobic fluidized bed: behaviour of organic suspended solids in anaerobic treatment of sewage. Proc. Seminar/Workshop: Anaerobic Treatment of Sewage, ed. Switzenbaum, Amherst, Mass., 161-197.

Young J. C. and Dahab M. F. (1983) Effect of media design on the performance of fixed-bed anaerobic reactors. Water Sci. Technol., $15(8 / 9), 369-383$.

Young J. C. (1991) Factors affecting the design and performance of upflow anaerobic filters. Water Sci. Technol., 24(8), 133-155. 


\section{Chapter 4}

\section{LOW TEMPERATURE TREATMENT OF DOMESTIC SEWAGE IN UPFLOW ANAEROBIC SLUDGE BLANKET AND ANAEROBIC HYBRID REACTORS}

Published as:

Elmitwalli T. A., Zandvoort M., Zeeman, G., Bruning, H. and Lettinga, G. (1999) Low temperature treatment of domestic sewage in upflow anaerobic sludge blanket and anaerobic hybrid reactors. Water Sci. Technol., 39(5), 177-185. 


\title{
LOW TEMPERATURE TREATMENT OF DOMESTIC SEWAGE IN UPFLOW ANAEROBIC SLUDGE BLANKET AND ANAEROBIC HYBRID REACTORS
}

\begin{abstract}
The treatment of sewage at a temperature of $13^{\circ} \mathrm{C}$ was investigated in an UASB and two anaerobic hybrid $(\mathrm{AH})$ reactors with small sludge granules with an average diameter of 0.73 $\mathrm{mm}$. The media used in the AH reactors were vertical sheets of reticulated polyurethane foam. The reactors were operated at an HRT of $8 \mathrm{~h}$. The use of small sludge granules and operating the reactors at low upflow velocity $(1.8 \mathrm{~m} / \mathrm{d})$ improved suspended COD removal efficiencies for the UASB reactor. Moreover, the use of sheets in the AH reactors significantly increased suspended COD removal efficiencies as compared to the UASB reactor and reached to $87 \%$ for pre-settled sewage treatment. The treatment of pre-settled sewage instead of raw sewage in $\mathrm{AH}$ reactors significantly increased colloidal and dissolved COD removal efficiencies with $13 \%$ and $12 \%$ respectively and colloidal COD removal efficiency for the UASB reactor with $13 \%$. At 'steady state' for pre-settled sewage treatment, the AH reactors removed $64 \%$ of the total COD which is significantly higher by $4 \%$ than the UASB reactor. Therefore, the anaerobic treatment of domestic sewage at low temperature can be improved by treating presettled sewage in shallow AH reactors containing small sludge granules.
\end{abstract}

\section{KEYWORDS}

Anaerobic treatment; domestic sewage; granular sludge; low temperature; reticulated polyurethane foam.

\section{INTRODUCTION}

Anaerobic digestion is an attractive process for the treatment of domestic sewage as little energy is needed for the process itself and moreover removed organic matter is converted to biogas which can be used for the production of energy. As hardly any nutrient are removed during digestion, the effluent of the treated sewage followed by pathogens removal is a valuable product for irrigation and fertilization to close the water and nutrients cycle. Therefore, anaerobic digestion of domestic wastewater is an attractive treatment system for community on-site (Lettinga et al. 1993; Lettinga, 1996). Although the anaerobic treatment of domestic sewage has been applied on a large scale in several tropical countries (Hulshoff Pol et al., 1997), the process is so far not applied on a full scale in countries with lower temperatures, mainly as results of lower removal efficiencies. Also, at low temperature, a longer HRT is needed (Imanori et al., 1983; Man et al., 1986; Lettinga, 1996) and the amount of the accumulated SS increases with decreasing temperature (Imanori et al., 1983; Genung et al., 1985; Sanz and Fdz-Polanco, 1990).

The removal and degradation of colloidal particles which represent $20-30 \%$ of the total COD $\left(\mathrm{COD}_{1}\right)$ for domestic sewage appear to become limiting in UASB reactors at lower 
temperatures (Mergaert et al., 1992). Wang (1994) mentioned that the removal and conversion of colloidal particles was the rate limiting step in a two step UASB+EGSB system treating raw sewage at an HRT of $3+2 \mathrm{~h}$ at low temperatures. He found average removal efficiencies for colloidal COD $\left(\mathrm{COD}_{\text {col }}\right)$ of $40 \%$ and $42 \%$ at temperatures of 17 and $12^{\circ} \mathrm{C}$ respectively. Yoda et al. (1985) also reported that the colloidal particles in the influent were difficult to remove and represented up to $60-70 \%$ of the effluent of an anaerobic fluidized bed reactor. Sayed and Fergala (1995) considered that the entrapment mechanism involved in removing solids is not sufficient to remove colloidal particles through the sludge bed with high porosity and under upflow and gasification. The results of fed batch recirculation experiment with raw and pre-settled sewage (Chapter 3 ) indicate that the presence of SS in the influent negatively affects on the removal of $\mathrm{COD}_{\mathrm{col}}$.

The UASB reactor inoculated with granular sludge showed a better performance than that inoculated with flocculant sludge (Lettinga et al., 1983). Anaerobic treatment of sewage with UASB and EGSB reactors using granular sludge have been studied extensively by Lettinga $e t$ al. (1983), Man et al. (1986), Last and Lettinga (1992) and Wang (1994) with large sludge granules. The recent researches in anaerobic granular sludge showed that the small sludge granules have a higher methanogenic activity than large sludge granules (Grotenhuis et al. 1991, Alphenaar, 1994, Rebac et al., 1997). The lower activity of large sludge granules may be due to the substrate transport limitations increase with the diameter of the granules (Alphenaar, 1994). The use of small sludge granules can also improve the filtration and entrapment mechanisms in the sludge bed which will lead to improving $\mathrm{COD}_{\mathrm{ss}}$ and $\mathrm{COD}_{\mathrm{col}}$ removal.

The performance of an anaerobic hybrid (AH) reactor depends on the contact of the wastewater with both the biomass in the sludge bed and attached and suspended biomass in the anaerobic filter $(\mathrm{AF})$ at the top of the reactor. Moreover, the AF layer helps in retaining biomass inside the reactor and gas/solids separation (Tilche and Vieira, 1991). Huysman et al. (1983) mentioned that reticulated polyurethane foam (RPF) appeared an excellent colonization matrix for AF. The RPF has a high specific surface area which can reach up to $2400 \mathrm{~m}^{2} / \mathrm{m}^{3}$ and high porosity of $97 \%$ (Huysman et al., 1983). The RPF is able to retain over $15 \mathrm{gVS} / \mathrm{l}$ in the attached form (Tilche and Vieira, 1991).

In the present research, the anaerobic treatment of sewage using UASB and AH reactors with small sludge granules have been investigated at a temperature of $13^{\circ} \mathrm{C}$. The RPF sheets were used as packing material (PM) which were oriented vertically with two different spacings. Also, the effect of influent $\mathrm{COD}_{\mathrm{ss}}$ concentration on the removal of $\mathrm{COD}_{\mathrm{col}}$ have been studied by operating the reactors with raw sewage, pre-settled sewage with settling time of $14 \mathrm{~h}$.

\section{MATERIALS AND METHODS}

\section{Experimental set-up}

Fig. 1 shows a schematic diagram of the experimental set-up. The experiment consisted of three reactors (each 3.84 l), one UASB reactor and two AH reactors. The three reactors have the same shape except for the gas/solids separator which is replaced by PM in the AH 
reactors. Each reactor, made of plexiglass, had a square cross section with $8 \mathrm{~cm}$ rib length. The height of each reactor was $70 \mathrm{~cm}$ with wastewater height of $60 \mathrm{~cm}$. The PM used were RPF sheets (type Filteren TM10 from Recticel, Buren, The Netherlands) which were oriented vertically in the AH reactors. Each sheet had knobs at one side while the other side was flat. The characteristics of the used RPF sheets are presented in Table 1.



Fig. 1. Schematic diagram of the experiment. 1, influent; 2, peristaltic pump; 3, UASB reactor; 4 , AH reactor with 3 sheets; 5 , AH reactor with 2 (raw sewage) or 4 sheets (presettled sewage); 6 , effluent; 7 , biogas; 8 , temperature controlled room at $13^{\circ} \mathrm{C}$.

Table 1. The characteristics of the RPF sheets used in the experiment

\begin{tabular}{lll}
\hline Parameter & Unit & Value \\
\hline Sheet width & $\mathrm{cm}$ & 8 \\
Total sheet thickness & $\mathrm{mm}$ & 20 \\
Base thickness & $\mathrm{mm}$ & 10 \\
Knob thickness & $\mathrm{mm}$ & 10 \\
Specific surface area & $\mathrm{m}^{2} / \mathrm{m}^{3}$ & 500 \\
Density & $\mathrm{kg} / \mathrm{m}^{3}$ & $19-22$ \\
Number of pores & pore/inch & $7-15$ \\
Pore size & $\mathrm{mm}$ & 2.5 \\
\hline
\end{tabular}

The two AH reactors varied from the number of RPF sheets. The first AH reactor contained 3 sheets corresponding to a spacing of $0.5 \mathrm{~cm}$ between the sheets. The second AH reactor contained 2 sheets corresponding to a spacing of $1.3 \mathrm{~cm}$ between the sheets. After 57 days of operation, the '2-sheets' reactor was modified to a '4-sheets' reactor without spacing between the sheets. The HRT for each reactor was $8 \mathrm{~h}$. For each reactor, the $\mathrm{CH}_{4}$ gas was collected by using a gas bag. The volume of $\mathrm{CH}_{4}$ was determined by pumping the biogas through a $\mathrm{NaOH}$ solution (3\%) and wet gas-meter. Dissolved $\mathrm{CH}_{4}$ in the effluent was calculated according to Henry's law and added to the produced $\mathrm{CH}_{4}$ gas. 


\section{Sewage}

The sewage used in the experiment was from the village Bennekom, The Netherlands. The sewage is collected in a combined sewer system and is continuously pumped to the experimental hall. The experiment was operated for the first 57 days with raw sewage and after that with pre-settled sewage from a $26 \mathrm{~m}^{3}$ settler with 2 hours settling time followed by a 35 litre settler in the refrigerator for 12 hours. The experiment with pre-settled sewage lasted for 93 days and was subsequently operated for 7 days with 2 hours pre-settled sewage. Table 2 shows COD fractions for sewage used in the experiment

Table 2. COD fractions for the sewage used in the experiment. Standard deviations are presented between two brackets.

\begin{tabular}{lccccc}
\hline Sewage & Period & \multicolumn{4}{c}{ COD (mg/l) } \\
\cline { 3 - 6 } & (days) & $\mathrm{COD}_{\mathrm{t}}$ & $\mathrm{COD}_{\mathrm{ss}}$ & $\mathrm{COD}_{\mathrm{col}}$ & $\mathrm{COD}_{\mathrm{dis}}$ \\
\hline Raw & 57 & $456(129)$ & $229(81)$ & $114(47)$ & $112(34)$ \\
Pre-settled (14 h settling & 93 & $339(70)$ & $82(34)$ & $136(27)$ & $124(36)$ \\
time) & & & & & \\
Pre-settled (2 h settling time) & 7 & $403(63)$ & $181(64)$ & $108(27)$ & $114(25)$ \\
\hline
\end{tabular}

\section{Sampling}

Sampling of the influent was made by using an additional head in the influent peristaltic pump. Composite samples for 24,48 and 72 hours of the influent and the effluent of each reactor were collected in containers stored in a refrigerator at $4^{\circ} \mathrm{C}$.

\section{Seed sludge}

The reactors were inoculated with granular sludge from a full scale UASB reactor treating alcohol wastewater from Nedalco, Alcohol producing industry, Bergen op Zoom, The Netherlands. The seed sludge granules had an average diameter of $0.73 \mathrm{~mm}$. The total amount of granular sludge added to each reactor was approximately $29 \mathrm{gVSS} /$.

\section{Analysis}

COD was analyzed using the micro-method as described by Jirka and Carter (1975). Raw samples were used for $\mathrm{COD}_{1}, 4.4 \mu \mathrm{m}$ folded paper filtered (Schleicher \& Schuell 5951/2) samples for $\mathrm{COD}_{\mathrm{f}}$ and $0.45 \mu \mathrm{m}$ membrane filtered (Schleicher Schuell ME 25) samples for dissolved $\mathrm{COD}\left(\mathrm{COD}_{\mathrm{dis}}\right)$. The $\mathrm{COD}_{\mathrm{ss}}$ and $\mathrm{COD}_{\mathrm{col}}$ were calculated by the differences between $C O D_{t}$ and $\mathrm{COD}_{f}, \mathrm{COD}_{\mathrm{f}}$ and $\mathrm{COD}_{\text {dis }}$ respectively. Volatile fatty acids (VFA) were measured from membrane filtered samples. VFA were determined by gas chromatography. The chromatograph (Hewlett Packard 5890A, Palo Alto, USA) was equipped with a $2 \mathrm{~m} \times 2 \mathrm{~mm}$ (inner diameter) glass column, packed with Supelco port (100-120 mesh) coated with 10\% Fluorad FC 431 . Operating condition were: column, $130^{\circ} \mathrm{C}$; injection port, $200^{\circ} \mathrm{C}$; flame ionization detector, $280^{\circ} \mathrm{C} . \mathrm{N}_{2}$ saturated with formic acid at $20^{\circ} \mathrm{C}$ was used as a carrier gas $(30 \mathrm{ml} / \mathrm{min})$. TS, VS, SS and VSS were measured according to the Dutch Standard Normalized Methods (1969). All measurements were determined in duplicate. 


\section{Statistical analysis}

Statistical Comparison between the performances of the reactors was done according to Snedecor and Cochran (1980). The performance of each reactor was assumed to be independent with different variance.

\section{RESULTS AND DISCUSSION}

\section{Reactors performance}

\section{Treatment of raw sewage}

The results of the performance of the reactors are shown in Table 3. In the start-up period, removal efficiencies of $\mathrm{COD}_{\mathrm{t}}$ improved with time. In the third week (from day 15 to day 23), COD, removal efficiencies reached to $72 \%, 72 \%$ and $70 \%$ for UASB, '3-sheets-AH' and '2sheets-AH' reactor respectively. After the start-up period (33 days), a part of the sludge bed in the UASB reactor floated to the gas solid separator and returned again with time. The floating and returning of the sludge bed occurred continuously until termination of the experiment with raw sewage. From visual observations, aggregation of individual granules followed by entrapment of biogas in the aggregates can be considered the main cause for sludge bed flotation. The presence of vertical sheets in the $\mathrm{AH}$ reactors prevented the flotation of the sludge bed and only channels and gas pockets were formed in the sludge bed. The channels and gas pockets disappeared with time and returned again in another place of the sludge bed. The $\mathrm{COD}_{\mathrm{t}}$ removal efficiencies of the UASB reactor and $\mathrm{AH}$ reactors were practically the same (Table 3). As the performance of the '2-sheets- $\mathrm{AH}^{\prime}$ reactor was similar to the '3-sheets$\mathrm{AH}$ ' reactor, another 2 sheets were added.

\section{Treatment of pre-settled sewage}

The operational period with pre-settled sewage is divided in three periods, acclimatization period (from day 1 to day 64), 'steady state' period (from day 64 to day 93) and SS shock load period (from day 93 to day 101). Table 3 summarized the results of treating pre-settled sewage in each reactor.

During the first two weeks of operation with pre-settled sewage, flotation of the sludge bed in the UASB and formation of channels and gas pockets in the sludge bed of the AH reactors still occurred although the influent $\mathrm{COD}_{\mathrm{ss}}$ decreased from $229 \mathrm{mg} / \mathrm{l}$ during the raw sewage period to $102 \mathrm{mg} / \mathrm{l}$ during the first two weeks of pre-settled sewage treatment. The sludge bed flotation and formation of channels and gas pockets gradually decreased with time and definitively stopped after two weeks. So, the sludge bed flotation in the UASB reactor and formation of channels and gas pockets in the sludge bed of the AH reactors can be attributed to high $\mathrm{COD}_{\mathrm{ss}}$ concentration of raw sewage. During the acclimatization period, the effluent $\mathrm{COD}_{t}, \mathrm{COD}_{\mathrm{col}}$ and $\mathrm{COD}_{\mathrm{dis}}$ concentration decreased with operation time.

After an acclimatization period of 64 days, removal efficiencies and effluent concentrations became more stable and standard deviation decreased. The reactors were considered to be in 'steady state' in this period. The criteria for 'steady state' set by Noyola et al. (1988) and Polprasert et al. (1992) were met during this period. Noyola et al. (1988) assumed 'steady 
state' of an anaerobic reactor treating domestic wastewater to be achieved after an operation time equal to 10 times the new HRT with a minimum of 2 weeks. Polprasert et al. (1992) considered 'steady state' when the effluent COD concentrations at the anaerobic treatment of slaughterhouse wastewater were constant or varied within $\pm 10 \%$.

The removal efficiency of $\mathrm{COD}_{1}$ was the same for the three reactors during the acclimatization period. At 'steady state', the AH reactors removed $64 \%$ of the COD, which is significantly higher by $4 \%$ than the UASB reactor (level $2.5 \%$ for ' 3 -sheets- $\mathrm{AH}$ ' reactor, level $5 \%$ for ' 4 sheets- $\mathrm{AH}^{\prime}$ reactor) mainly caused by significantly better removal of $\mathrm{COD}_{\text {col }}$ (level $0.5 \%$ for '3-sheets-AH' reactor, level $2.5 \%$ for '4-sheets-AH' reactor). Although, the pre-settled sewage $\mathrm{COD}_{\mathrm{ss}}$ concentration was low, the three reactors showed better removal efficiencies for $\mathrm{COD}_{\mathrm{ss}}$ than that found in previous researches at the same temperature probably due to operating the reactors at low upflow velocity and the use of small sludge granules. The use of sheets in the $\mathrm{AH}$ reactors significantly increased $\mathrm{COD}_{\mathrm{ss}}$ removal efficiency compared to the UASB reactor for the whole period of pre-settled sewage treatment.

No significant differences were found for $\mathrm{COD}_{\text {dis }}$ removal efficiency between the $\mathrm{AH}$ reactors and the UASB reactor. Although the reactors were operated at low upflow velocity $(0.075$ $\mathrm{m} / \mathrm{h}$ ), it seemed that there was a sufficient contact between dissolved substrate and biomass. The average $\mathrm{COD}_{\text {dis }}$ removal efficiencies during 'steady state' for the UASB, '3-sheets-AH' and ' 4 -sheets-AH' reactor represented respectively $91 \%, 96 \%$ and $94 \%$ of the maximum removal efficiency of $54 \%$ achieved by Last and Lettinga (1992) at batch recirculation of pre-settled sewage at upflow velocity of $6 \mathrm{~m} / \mathrm{h}$. VFA were completely removed in all reactors indicating that methanogenesis was not rate limiting. The use of small sludge granules, which have less substrate transport limitations (Alphenaar, 1994), may be the reason of high removal efficiency for $\mathrm{COD}_{\text {dis }}$ and complete removal of VFA.

The shock load of $\mathrm{COD}_{s s}$ did not affect the overall removal efficiency of the three reactors while the effluent COD concentration increased. The effluent concentration of $\mathrm{COD}_{\mathrm{col}}$ increased for all reactors and removal efficiency decreased considerable. The decrease in removal efficiency of $\mathrm{COD}_{\text {col }}$ might be caused by production of colloidal from extra SS in the influent.

No significant difference was shown between the performance of the '3-sheets- $\mathrm{AH}$ ' and '4sheets- $\mathrm{AH}$ ' reactor except for $\mathrm{COD}_{\text {dis }}$ which was significantly better at level $10 \%$ for the '4sheets-AH' as compared to the ' 3 -sheets-AH' reactor at applying the SS shock load.

\section{Biogas production}

The results of methane production of the ' 3 -sheets- $\mathrm{AH}$ ' reactor are summarized in Table 4. The average methane production during raw sewage treatment was similar to that found by Lettinga et al. (1983) $\left(0.21 \mathrm{~m}^{3} \mathrm{CH}_{4} / \mathrm{kg}\right.$ COD removed), by Kobayashi et al. (1983) $\left(0.16 \mathrm{~m}^{3}\right.$ $\mathrm{CH}_{4} / \mathrm{kg}$ COD removed) or by Noyola et al. (1989) $\left(0.17 \mathrm{~m}^{3} \mathrm{CH}_{4}\right.$ (STP)/kg COD removed). Moreover, the methane production increased with pre-settled sewage treatment and the conversion of removed COD to methane was higher than the theoretical value $\left(0.35 \mathrm{~m}^{3} \mathrm{CH}_{4}\right.$ (STP)/kg COD removed) during 'steady state'. Although, the reactors met the 'steady state' based on the stability of the effluent COD concentration as mentioned by Noyola et al. (1988) 





and Polprasert et al (1992), the high methane production showed that a real steady state was not achieved. The extra methane was presumably produced from the hydrolysis of SS accumulated in the sludge bed during the raw sewage treatment.

Table 4. Methane production during the treatment of raw sewage and pre-settled sewage. standard deviations are shown between two brackets.

\begin{tabular}{lcccc}
\hline Sewage & Period & \multicolumn{2}{c}{ Methane production } & \begin{tabular}{c} 
Conversion \\
of removed \\
COD to \\
\cline { 3 - 5 }
\end{tabular} \\
\cline { 3 - 5 } & $\begin{array}{c}\mathrm{m}^{3} \mathrm{CH}_{4}(\mathrm{STP}) / \mathrm{kg} \\
\mathrm{COD} \text { added }\end{array}$ & $\begin{array}{c}\mathrm{m}^{3} \mathrm{CH}_{4}(\mathrm{STP}) / \mathrm{kg} \\
\mathrm{COD} \text { removed }\end{array}$ \\
\hline Raw & from day 38 to 57 & $0.17(0.03)$ & $0.25(0.04)$ & $72(12)$ \\
& acclimatization & $0.18(0.04)$ & $0.30(0.06)$ & $86(17)$ \\
& 'steady state' & $0.25(0.04)$ & $0.39(0.07)$ & $112(20)$ \\
\hline
\end{tabular}

\section{Wasted sludge}

The sludge was wasted two times mainly from the top of the sludge bed for maintaining the sludge bed almost at the same level (Table 5). Miron (1997) mentioned that sludge residence time (SRT) plays a crucial rule in anaerobic treatment and SRT is an efficient parameter in controlling the process. Calculating the SRT from total biomass in the reactor and wasted biomass gave a high SRT ( $>500 \mathrm{~d}$ ) for all reactors. The wasted biomass mainly contained flocculant sludge while the biomass in the reactors was mainly granular sludge. Separation between SRT of flocculant sludge and granular sludge is more realistic. However, accurate separating and measuring of flocculant sludge and granular sludge was difficult especially in the $\mathrm{AH}$ reactors which contained attached biomass to the media.

\section{Comparison between the treatment of raw sewage and pre-settled sewage}

The treatment of raw sewage in the UASB reactor with small sludge granules under lower upflow velocity and temperature seemed to be not practical due to the sludge bed flotation. The high influent $\mathrm{COD}_{\mathrm{ss}}$ was the reason for sludge bed flotation. The presence of RPF sheets in the $\mathrm{AH}$ reactor prevented sludge bed flotation and only channels and gas pockets were formed in the sludge bed of the $\mathrm{AH}$ reactors.

Table 5. Wasted sludge during the treatment of raw and pre-settled sewage

\begin{tabular}{|c|c|c|c|}
\hline Time & $\begin{array}{c}\text { UASB reactor } \\
\text { (g VSS/d) }\end{array}$ & $\begin{array}{l}\text { '3-sheets-AH' } \\
\text { reactor } \\
\text { (g VSS/d) }\end{array}$ & $\begin{array}{c}2 \text { or } 4 \text { sheets-AH' } \\
\text { reactor } \\
(\mathrm{gVSS} / \mathrm{d})\end{array}$ \\
\hline At the end of raw sewage treatment & 0.21 & 0.21 & 0.22 \\
\hline $\begin{array}{l}\text { After } 41 \text { days of pre-settled sewage } \\
\text { treatment }\end{array}$ & 0.16 & 0.15 & 0.17 \\
\hline
\end{tabular}

The treatment of pre-settled sewage instead of raw sewage improved $\mathrm{COD}_{\mathrm{col}}$ removal efficiency of the UASB reactor by $13 \%$ (from $46 \%$ to $59 \%$ ) and this difference was significant at level $2.5 \%$. The '3-sheets- $A H^{\prime}$ reactor removal efficiency for $\mathrm{COD}_{\mathrm{col}}$ as well as $\mathrm{COD}_{\text {dis }}$ improved significantly (level $10 \%$ ) by $13 \%$ (from $44 \%$ to $57 \%$ ) and $12 \%$ (from $36 \%$ to $48 \%$ ) respectively. The reduced $\mathrm{COD}_{\mathrm{ss}}$ levels in the influent of the pre-settled sewage are quite 
likely the cause of the improved $\mathrm{COD}_{\mathrm{cot}}$ removal. The latter indicates that part of the colloids in the effluent at the anaerobic treatment of raw sewage is produced from SS in the influent.

Wang (1994) showed that a high loaded UASB (HRT $=3$ hours) resulted in winter $\left(12^{\circ} \mathrm{C}\right)$ in a $\mathrm{COD}_{\mathrm{ss}}$ removal efficiency of $44 \%$ and a mean effluent of $110 \mathrm{mg} \mathrm{COD}_{\mathrm{ss}} / \mathrm{l}$. As a result of the high upflow velocity in the subsequent EGSB reactor the total removal efficiency of $\mathrm{COD}_{\mathrm{col}}$ amount to $42 \%$. Combination of a high loaded UASB with a hybrid system could improve both the $\mathrm{COD}_{\mathrm{ss}}$ and the $\mathrm{COD}_{\mathrm{col}}$ removal, finally resulting in a high $\mathrm{COD}_{\mathrm{t}}$ removal efficiency at $13^{\circ} \mathrm{C}$ at an HRT of 11 hours for the two systems together. The proposed two-step system could be attractive for raw sewage treatment at low temperatures especially for community on-site. Optimization of the process with respect to HRT and upflow velocity should be provided.

\section{CONCLUSIONS}

The use of small sludge granules and operating the reactors at low upflow velocity improved suspended COD removal efficiencies for the UASB reactor. Moreover, the use of sheets in the $\mathrm{AH}$ reactors significantly increased $\mathrm{COD}_{\mathrm{ss}}$ removal efficiencies as compared to the UASB reactor and reached to $87 \%$ for pre-settled sewage treatment.

The treatment of pre-settled sewage instead of raw sewage in $\mathrm{AH}$ reactors significantly increased $C O D_{c o l}$ and $C O D_{\text {dis }}$ removal efficiencies with $13 \%$ and $12 \%$ respectively and $C O D_{c o r}$ removal efficiency for the UASB reactor with $13 \%$.

At 'steady state' conditions of pre-settled sewage treatment, the AH reactors removed $64 \%$ of the $\mathrm{COD}_{\text {, }}$ which was significantly higher by $4 \%$ than the UASB reactor.

\section{ACKNOWLEDGEMENTS}

We acknowledge the Egyptian Ministry of Higher Education for the scholarship given for the first author. We grateful to Recticel, Buren, The Netherlands for providing the polyurethane foam sheet. We are also grateful to: R.E. Roersma, B. Willemsen, D. van Doorn, J. van der Laan, H. Donker and Ilse Bennehey for technical support.

\section{REFERENCES}

Alphenaar A. (1994) Anaerobic granular sludge: characterization and factors affecting its functioning. Ph. D. thesis, Department of Environmental Technology, Wageningen University, The Netherlands.

Dutch Standard Normalized Methods (1969) The Netherlands Normalisation Institute, Delft, The Netherlands.

Genung R. K., Donaldson T. L. and Reed G. D. (1985) Pilot-scale development of anaerobic filter technology for municipal wastewater treatment. Proc. Seminar/Workshop: Anaerobic Treatment of Sewage, Amherst, Mass., 127-160. 
Grotenhuis J. T. C., Kissel J. C., Plugge C. M., Stams A. J. M. and Zehnder A. J. B. (1991) Role of substrate concentration in particle size distribution of methanogenic granular sludge in UASB reactors. Water Res., 25, 21-27.

Hulshoff Pol L., Euler H., Eitner A. and Grohganz T. B. W. (1997) State of the art sector review. Anaerobic Trends. WQI july/august, 31-33.

Huysman P., Meenen P. van, Assche P. van and Verstraete W. (1983) Factors affecting the colonization of non porous and porous packing materials in model upflow methane reactors. Biotechnol. Lett., 5(9), 643-648.

Inamori Y., Sudo R. and Goda T. (1986) Domestic sewage treatment using an anaerobic biofilter with an aerobic biofilter. Water Sci. Technol., 18(12), 209-216.

Jirka A. and Carter (1975) Micro Semi-automated analysis of surface and waste waters for chemical oxygen demand. Analytical Chemistry, 47, 1397-1401.

Last A. R. M. van der and Lettinga G. (1992) Anaerobic treatment domestic sewage under moderate climatic (Dutch) conditions using upflow reactors at increased superficial velocities. Water Sci. Technol., 25(7), 167-178.

Lettinga G., Roersma R., Grin P., Zeeuw W. de, Hulshoff Pol L., Velsen L. van, Hombma S. and Zeeman G. (1981) Anaerobic treatment of sewage and low strength wastewater. Proc. 2nd. Int. Symp. on Anaerobic Digestion, Travemunde, 271-291

Lettinga G., Roersma R. and Grin P. (1983) Anaerobic treatment of raw domestic sewage at ambient temperatures using a granular bed UASB reactor. Biotechnol. and Bioeng., 25. 1701-1723.

Lettinga G., Man A. W. A. de, Last A. R. M. van der, Wiegant W., Knippenberg K. van, Frijns J. and Buuren J. C. L. van (1993) Anaerobic treatment of domestic sewage and wastewater. Water Sci. Technol., 27(9), 67-73.

Lettinga G. (1996) Sustainable integrated biological wastewater treatment. Water Sci. Technol, 33(3), 85-98.

Man A.W.A. de, Grin P.C., Roesma R., Grolle K.C.F. and Lettinga G. (1986) Anaerobic treatment of sewage at low temperatures. Proc. Anaerobic Treatment a Grown-up Technology, Amsterdam, The Netherlands, 451-466.

Mergaert K., Vanderhaegen B. and Verstraete W. (1992) Application and trends of anaerobic pre-treatment of municipal wastewater. Water Res., 26, 1025-1033.

Miron Y. (1997) Anaerobic treatment of concentrated sewage in a two step UASR-UASB system: The effect of SRT, sludge characteristics and upflow velocity on the performance of the UASR, Report 97-51, Wageningen Agricultural university, The Netherlands.

Noyola A., Capdeville B. and Roques (1988) Anaerobic treatment of domestic wastewater with a rotating-stationary fixed-film reactor. Water Res., 22(12), 1585-1592.

Polprasert C., Kemmadamnrong P., Tran F.T. (1992) Anaerobic baffle reactor (ABR) process for treating slaughterhouse wastewater. Environm. Technol., 13, 857-865.

Rebac S., Lier J. van, Janssen M. G. J, Dekkers F., Swinkels K. T. M and Lettinga G. (1997) High-rate anaerobic treatment of malting wastewater in a pilot-scale EGSB system under psychrophilic conditions. J. Chem. Technol. Biotechnol., 68, 135-146.

Sanz I. and Fdz-Polanco F. (1990) Low temperature treatment of municipal sewage in anaerobic fluidized bed reactors. Water. Res. , 24, 463-469.

Sayed S. K. I. and Fergala M. A. A. (1995) Two-stage UASB concept for treatment of domestic sewage including sludge stabilization process. Water Sci. Technol, 32(11), 55 63. 
Snedecor G. W. and Cochran W. G. (1980) Statistical methods. The Iowa state university press, Ames, Iowa, USA.

Tilche A. and Vieira S. M. M. (1991) Discussion report on reactor design of anaerobic filters and sludge bed reactors. Water Sci. Technol., 24 (8), 193-206.

Wang K. (1994) Integrated Anaerobic and Aerobic Treatment of Sewage. Ph. D. thesis, Department of Environmental Technology, Wageningen University, The Netherlands.

Yoda M., Hattori M. and Miyaji Y. (1985) Treatment of municipal wastewater by anaerobic fluidized bed: behaviour of organic suspended solids in anaerobic treatment of sewage. Proc. Seminar/Workshop: Anaerobic Treatment of Sewage, Amherst, Mass., 161-197. 


\section{Chapter 5}

\section{LOW TEMPERATURE PRE-TREATMENT OF DOMESTIC SEWAGE IN AN ANAEROBIC HYBRID AND AN ANAEROBIC FILTER REACTOR}

\section{Presented/Submitted as:}

Elmitwalli T. A., Sklyar V., Zeeman G. and Lettinga, G. (1999) Low temperature pretreatment of domestic sewage in an anaerobic hybrid and an anaerobic filter reactor. Proc. $4^{t h}$ IAWQ Conference in Biofilm System. 16-20 October, New York.

Elmitwalli T. A., Sklyar V., Zeeman G. and Lettinga G. (submitted) Low temperature pretreatment of domestic sewage in an anaerobic hybrid and an anaerobic filter reactor. Biores. Technol. 


\title{
LOW TEMPERATURE PRE-TREATMENT OF DOMESTIC SEWAGE IN AN ANAEROBIC HYBRID AND AN ANAEROBIC FILTER REACTOR
}

\begin{abstract}
The pre-treatment of domestic sewage for removal of suspended solids at a process temperature of $13^{\circ} \mathrm{C}$ and an HRT of $4 \mathrm{~h}$ was investigated in an anaerobic filter (AF) and anaerobic hybrid $(\mathrm{AH})$ reactor. The $\mathrm{AF}$ and the top of the $\mathrm{AH}$ reactor consisted of vertical sheets of reticulated polyurethane foam with knobs. The biomass in the AF reactor was only in attached form to avoid clogging and sludge wash-out. The AF reactor showed a significantly higher removal for total and suspended COD than the AH reactor, viz. respectively 55 and $82 \%$ in the AF reactor and 34 and $53 \%$ in the $\mathrm{AH}$ reactor. Because the reactors were operated at a short HRT and low temperature, the hydrolysis, acidification and methanogenesis were limited to respectively 12,21 and $23 \%$ for the $\mathrm{AF}$ reactor and 12 , 17 and $16 \%$ for the $\mathrm{AH}$ reactor. The excess sludge from the $\mathrm{AH}$ reactor was more stabilized and had a better settlability and dewaterability. However, the excess sludge from the AH reactor needs also post stabilization. Therefore, the AF reactor is recommended for the pretreatment of domestic sewage at low temperatures.
\end{abstract}

\section{KEYWORDS}

Anaerobic filter; anaerobic hybrid; domestic sewage; polyurethane foam; wastewater pretreatment.

\section{INTRODUCTION}

High-rate anaerobic treatment is becoming more and more applied for the treatment of domestic sewage especially for developing countries because of low construction, operation and maintenance costs, small land requirements, low excess sludge production and biogas production. For tropical areas where the temperature ranges between $20-35^{\circ} \mathrm{C}$, the anaerobic process holds prospects for the treatment of domestic sewage (Haandel and Lettinga, 1994). Moreover, experimental results showed that the anaerobic treatment should not be excluded at low temperatures (Lettinga et al., 1983; Genung et al., 1985; Man et al., 1986; Sanz and FdzPolanco, 1990; Elmitwalli et al., 1999). However, at low temperatures, chemical oxygen demand (COD) removal efficiency is lower, a longer hydraulic retention time (HRT) is needed and the amount of accumulated suspended solids (SS) in the anaerobic reactor increases due to the lower hydrolysis rate (Inamori et al., 1983; Genung et al., 1985; Man et al., 1986; Sanz and Fdz-Polanco, 1990; Zeeman and Lettinga, 1999).

Uemura and Harada (2000), recently, showed that the treatment of raw domestic sewage in a upflow anaerobic sludge blanket (UASB) reactor with granular sludge bed at low temperatures of $13^{\circ} \mathrm{C}$ causes deterioration of the methanogenic activity and reactor performance as a result of accumulation of SS, when an HRT of $4.7 \mathrm{~h}$ is applied. Pre-removal 
of SS is therefore needed, when domestic sewage is treated in a UASB reactor at short HRT and low temperature. Elmitwalli et al. (1999) demonstrated that removal of suspended COD $\left(\mathrm{COD}_{\mathrm{ss}}\right)$ in a subsequent methanogenic anaerobic hybrid $(\mathrm{AH})$ reactor, moreover, resulted in an improved removal of colloidal $\mathrm{COD}\left(\mathrm{COD}_{\mathrm{col}}\right)$ and dissolved $\mathrm{COD}\left(\mathrm{COD}_{\mathrm{dis}}\right)$.

Zeeman et al. (1997) applied a flocculant high loaded UASB system for the pre-removal of SS prior to a methanogenic EGSB (expanded granular sludge bed) reactor. Though for the high loaded UASB reactor with an $\mathrm{HRT}$ of $3 \mathrm{~h}$ at $12^{\circ} \mathrm{C}$, the removal efficiencies for $\mathrm{COD}_{\mathrm{ss}}$ were $42 \%$, the later might be increased by application of an anaerobic filter (AF) or $\mathrm{AH}$ reactor (Elmitwalli et al., 2000).

The $\mathrm{AH}$ reactor, which consists of a sludge bed in the lower part and an $\mathrm{AF}$ in the upper part combines advantages of UASB and AF reactors, while minimising their limitations (Tilche and Vieira, 1991). The filter zone in the AH reactor, in addition to its physical role for biomass retention, has some biological activity contributing to COD reduction in a zone which is lacking biomass in a classical UASB reactor (Tilche and Vieira, 1991). Oriented and porous media in the $\mathrm{AF}$ reactor provide better performance than random and non-porous media respectively (Huysman et al. 1983; Young, 1991; Anderson et al., 1994). Huysman et al. (1983) reported that reticulated polyurethane foam (porous media) offers an excellent colonisation matrix for the AF reactor. The reticulated polyurethane foam (RPF) has a high specific surface area, which can reach up to $2400 \mathrm{~m}^{2} / \mathrm{m}^{3}$ and a high porosity of $97 \%$ (Huysman et al., 1983). The RPF therefore enables the retention over $15 \mathrm{gVS} / \mathrm{l}$ in attached form (Tilche and Vieira, 1991). RPF also has the ability to entrap SS from domestic sewage. Elimitwalli et al. (2000) showed that clean vertical sheets of RPF were efficient in removing $\mathrm{COD}_{\mathrm{ss}}(>75 \%)$ in domestic sewage even at a short HRT as low as $0.5 \mathrm{~h}$ and at high upflow velocity as high as $10 \mathrm{~m} / \mathrm{h}$.

The objective of the present research is to compare between the performance of an $\mathrm{AH}$ and an $\mathrm{AF}$ reactor for the pre-treatment of domestic sewage at a low temperature of $13^{\circ} \mathrm{C}$.

\section{MATERIALS AND METHODS}

\section{Experimental set-up}

A schematic diagram of the experimental set-up is shown in Fig. 1. The experimental arrangement consisted of two reactors made of plexiglas, an $\mathrm{AH}$ reactor and an $\mathrm{AF}$ reactor. Table 1 shows the dimensions and the operational conditions of the reactors. The media used in the reactors were RPF sheets (type Filteren TM10 from Recticel, Buren, The Netherlands), oriented vertically without spacing. Each sheet had knobs at one side, while the other side was flat. The characteristics of the used RPF sheets are presented in Table 2. The temperature was controlled at $13^{\circ} \mathrm{C}$ by recirculating thermostated water of $13^{\circ} \mathrm{C}$ through a tube around the reactors.

\section{Sewage}

The sewage used in the experiment originated from the village Bennekom. The sewage is 
collected in a combined sewer system and is continuously pumped to the experimental hall. Table 3 shows the COD fractions of the used domestic sewage. Two 48 hours composite samples from the domestic sewage and the effluent of each reactor were collected weekly in containers and stored in a refrigerator at $4^{\circ} \mathrm{C}$.

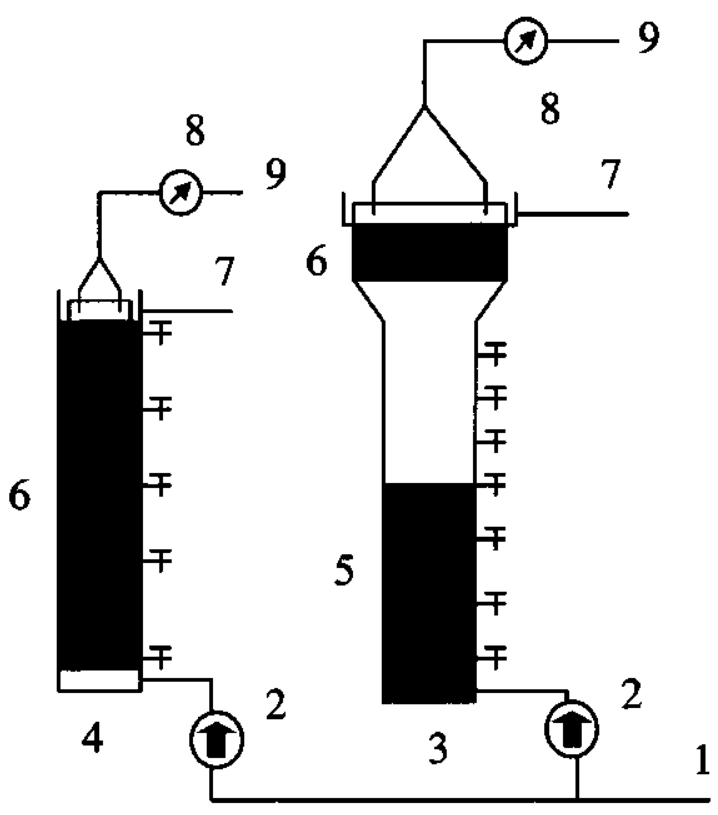

Fig. 1. Schematic diagram of the experiment. 1, influent; 2, peristaltic pump; 3, AH reactor; 4, $\mathrm{AF}$ reactor; 5 , sludge bed; 6 , filter media; 7 , effluent; 8 , gas-meter; 9 , biogas.

Table 1. Dimensions and operation conditions of the AF and $\mathrm{AH}$ reactor

\begin{tabular}{lcc}
\hline Parameter & AF reactor & AH reactor \\
\hline Height (m) & 2.10 & 2.55 \\
Diameter (m) & 0.19 & 0.19 for the sludge bed part \\
& & and 0.30 for the AF part \\
Media height (m) & 1.75 & 0.40 \\
Volume (l) & 60 & 88 \\
HRT (h) & 4 & 4 \\
\hline
\end{tabular}

\section{Reactors start-up and sludge wastage}

The $\mathrm{AH}$ reactor was inoculated with digested primary sludge from the wastewater treatment 
plant of Ede, The Netherlands. The sludge bed in the AH reactor was slowly mixed for 5 seconds every 15 minutes to reduce channels and dead zones formation in the sludge bed. All accumulated sludge on the bottom of the AF was wasted once per week. The sludge bed height in the $\mathrm{AH}$ reactor was controlled at $1 \mathrm{~m}$ by wasting the upper part of the sludge bed. The two reactors were operated for 140 days and by monitoring the biogas production, the first 50 days were considered as a start-up period.

Table 2. The characteristics of the RPF sheets used in the experiment

\begin{tabular}{lcc}
\hline Parameter & Unit & Value \\
\hline Total sheet thickness & $\mathrm{mm}$ & 25 \\
Knob thickness & $\mathrm{mm}$ & 15 \\
Base thickness & $\mathrm{mm}$ & 10 \\
Specific surface area & $\mathrm{m}^{2} / \mathrm{m}^{3}$ & 500 \\
Pore size & $\mathrm{mm}$ & 2.5 \\
\hline
\end{tabular}

Table 3. COD fractions and VFA-COD concentration for the domestic sewage used in the experiment. Standard deviations are presented in brackets

\begin{tabular}{lccccc}
\hline & $\mathrm{COD}_{\mathrm{t}}^{\mathrm{a}}$ & $\mathrm{COD}_{\mathrm{ss}}$ & $\mathrm{COD}_{\text {col }}$ & $\mathrm{COD}_{\text {dis }}$ & VFA-COD \\
\hline Concentration & 518 & 207 & 133 & 178 & 40 \\
$(\mathrm{mg} / \mathrm{l})$ & $(222)$ & $(138)$ & $(47)$ & $(65)$ & $(22)$ \\
\hline
\end{tabular}

${ }^{\mathrm{a}} \mathrm{COD}_{\mathrm{t}}=$ total $\mathrm{COD}$

\section{Analysis}

COD was analysed using the micro-method as described by Jirka and Carter (1975). Raw samples were used for $\mathrm{COD}_{\mathfrak{v}}, 4.4 \mu \mathrm{m}$ folded paper-filtered (Schleicher \& Schuell 59512, Germany) samples for $\mathrm{COD}_{\mathrm{f}}$ and $0.45 \mu \mathrm{m}$ membrane-filtered (Schleicher \& Schuell ME 25, Germany) samples for $\mathrm{COD}_{\mathrm{dis}}$. The $\mathrm{COD}_{\mathrm{ss}}$ and $\mathrm{COD}_{\mathrm{col}}$ were calculated by the differences between $C O D_{1}$ and $C O D_{f}, C O D_{f}$ and $C_{\text {dis }}$ respectively. Volatile fatty acids (VFA) were measured from membrane-filtered samples by gas chromatography (Hewlett Packard 5890A, Palo Alto, USA). The biogas composition with respect to $\mathrm{CH}_{4}, \mathrm{CO}_{2}, \mathrm{~N}_{2}$ and $\mathrm{O}_{2}$ content was determined by using Fisons gas chromatograph model GC 8000 series. Sludge volume index (SVI), capillary suction time (CST), total solids (TS), volatile solids (VS), SS and volatile suspended solids (VSS) were measured according to the Dutch Standard Normalized Methods (1969). Sludge digestibility was done as described by Lier (1995) for a period of 60 days. All measurements were determined in duplicate.

\section{Calculations}

The percentages of hydrolysis $(\mathrm{H})$, acidification $(\mathrm{A})$ and methanogenesis $(\mathrm{M})$ in each reactor were calculated according to equations 1,2 and 3 respectively. The maximum (SRT max $_{\text {max }}$ ) and minimum $\left(\mathrm{SRT}_{\min }\right.$ ) sludge residence time were calculated according to equations 4 and 5 respectively. For calculating the SRT $T_{\text {max }}$, it was assumed that the effluent VSS was a part of the influent VSS with a residence time equal to the HRT, while for calculating the SRT min $_{\text {in }}$, it was assumed that the effluent VSS had the same SRT as the excess sludge. Due to the 
presence of channels and dead zones in the sludge bed of the anaerobic reactor (Bolle et al., 1986; Man et al., 1988), the actual SRT for each reactor is between $S_{\text {ST }}$ max and SRT min. The $_{\text {. }}$ amount of dissolved $\mathrm{CH}_{4}$ in the effluent was calculated according Henry's Law. The filterability constant $(\chi)$ was calculated according to Vesilind (1988) with an apparatus constant of 0.794 .

$$
\begin{aligned}
& H=100\left(\frac{C H_{4} \text { as } C O D+\text { effluent } C O D_{\text {dis }}-\text { influent } C O D_{\text {dis }}}{\text { influent } C O D_{s s}+\text { influent } C O D_{c o l}}\right) \\
& A=100\left(\frac{C H_{4} \text { as } C O D+\text { effluent VFA as } C O D-\text { influent VFA as } C O D}{\text { influent } C O D_{t}-\text { influent VFA as } C O D}\right) \\
& M(\%)=100\left(\frac{C H_{t} \text { as } C O D}{\text { influent } C O D_{t}}\right) \\
& S R T_{\max }=\left(\frac{V \times X}{Q_{w} \times X_{w}}\right) \\
& S R T_{\min }=\left(\frac{V \times X}{Q_{w} \times X_{w}+Q \times X_{e}}\right)
\end{aligned}
$$

Where: V, reactor volume (1); X, average shudge concentration in the reactor (mg VSS/l); $\mathrm{Q}_{w}$, excess sludge flow rate $(1 / \mathrm{d}) ; \mathrm{X}_{w}$, concentration of the excess sludge (mg VSS/l); $Q$, wastewater flow rate $(1 / \mathrm{d}) ; \mathrm{X}_{e}$, effluent concentration (mg VSS/l) and according to Zeeuw (1984) $\mathrm{X}_{\mathrm{e}}=\mathrm{COD}_{\mathrm{ss}} / 1.4$.

\section{RESULTS AND DISCUSSION}

\section{COD and VFA removal efficiencies}

The efficiency of the reactors for the different COD fractions and for VFA is presented in Fig. 2 and Table 4. The results in Fig. 2 clearly show that the AF reactor provides a better removal for $\mathrm{COD}_{t}$ as compared to the $\mathrm{AH}$ reactor and moreover the performance of the $\mathrm{AF}$ was more stable. The higher removal of $\mathrm{COD}_{\mathrm{ss}}$ in the $\mathrm{AF}$ reactor as compared to the $\mathrm{AH}$ reactor is the main reason for the higher removal of $\mathrm{COD}_{\mathrm{t}}$. Also, the removal of $\mathrm{COD}_{\mathrm{col}}$ and $\mathrm{COD}_{\mathrm{dis}}$ generally were higher in the AF reactor (Fig. 2.3 and 2.4).

\section{Methane production, hydrolysis and acidification}

The methane content of the produced biogas in the AF and $\mathrm{AH}$ reactor were $70.7 \pm 2.9 \%$ and $58.9 \pm 3.2 \%$ respectively. The amount of biogas produced from the AF reactor was always higher as compared to the AH reactor. Fig. 3 shows the course of the hydrolysis, acidification and methanogenesis in the $\mathrm{AF}$ and $\mathrm{AH}$ reactor in time. The considerable fluctuations in the domestic sewage concentration and composition led to high standard deviations in the mean value for hydrolysis, acidification and methanogensis (Table 5). Since the AF and AH reactor were operated in parallel with the same domestic sewage, a good comparison between the two reactors can moreover be made from Fig. 3. Both methanogenesis and acidification were higher for the $\mathrm{AF}$ reactor than for the $\mathrm{AH}$ reactor, while the hydrolysis was similar. 

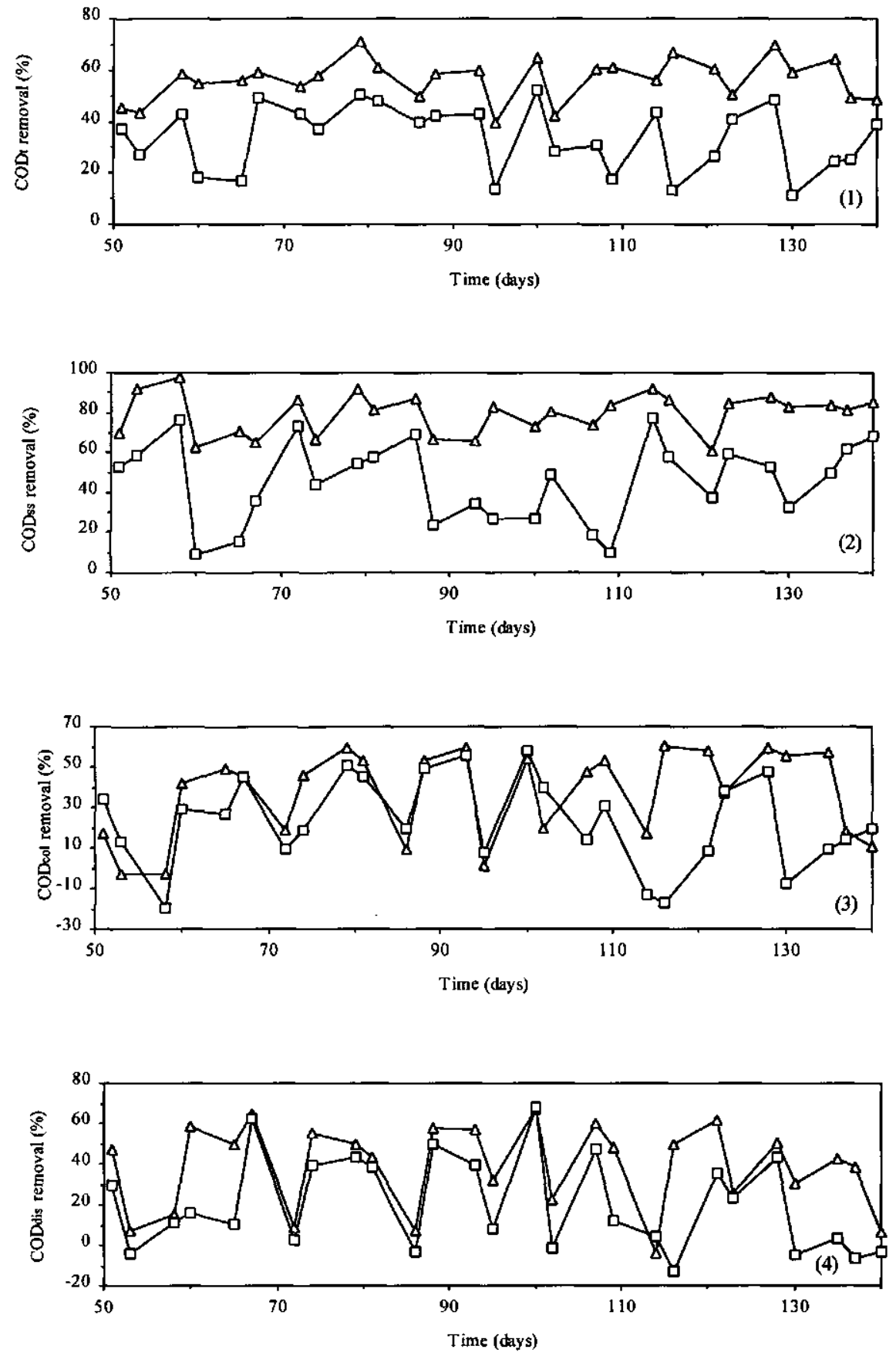

Fig. 2. $C O D_{1}$ and $C O D$ fractions removal efficiencies in the treatment of domestic sewage in the $\mathrm{AF}$ and $\mathrm{AH}$ reactor. (1), $\mathrm{COD}_{i} ;(2), \mathrm{COD}_{\mathrm{ss}} ;(3), \mathrm{COD}_{\mathrm{col}} ;(4), \mathrm{COD}_{\text {dis }}(\Delta), \mathrm{AF}$ reactor; ( $\square$ ), $\mathrm{AH}$ reactor. 


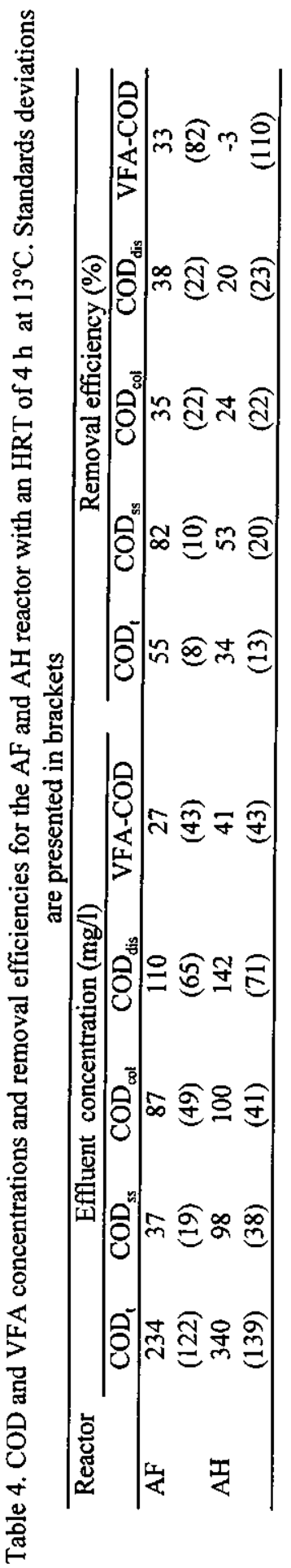


The hydrolysis based on the removed particulate $\mathrm{COD}$ was higher for the $\mathrm{AH}$ reactor $(39 \pm 12 \%)$ than that for $\mathrm{AF}$ reactor $(16 \pm 11 \%)$.
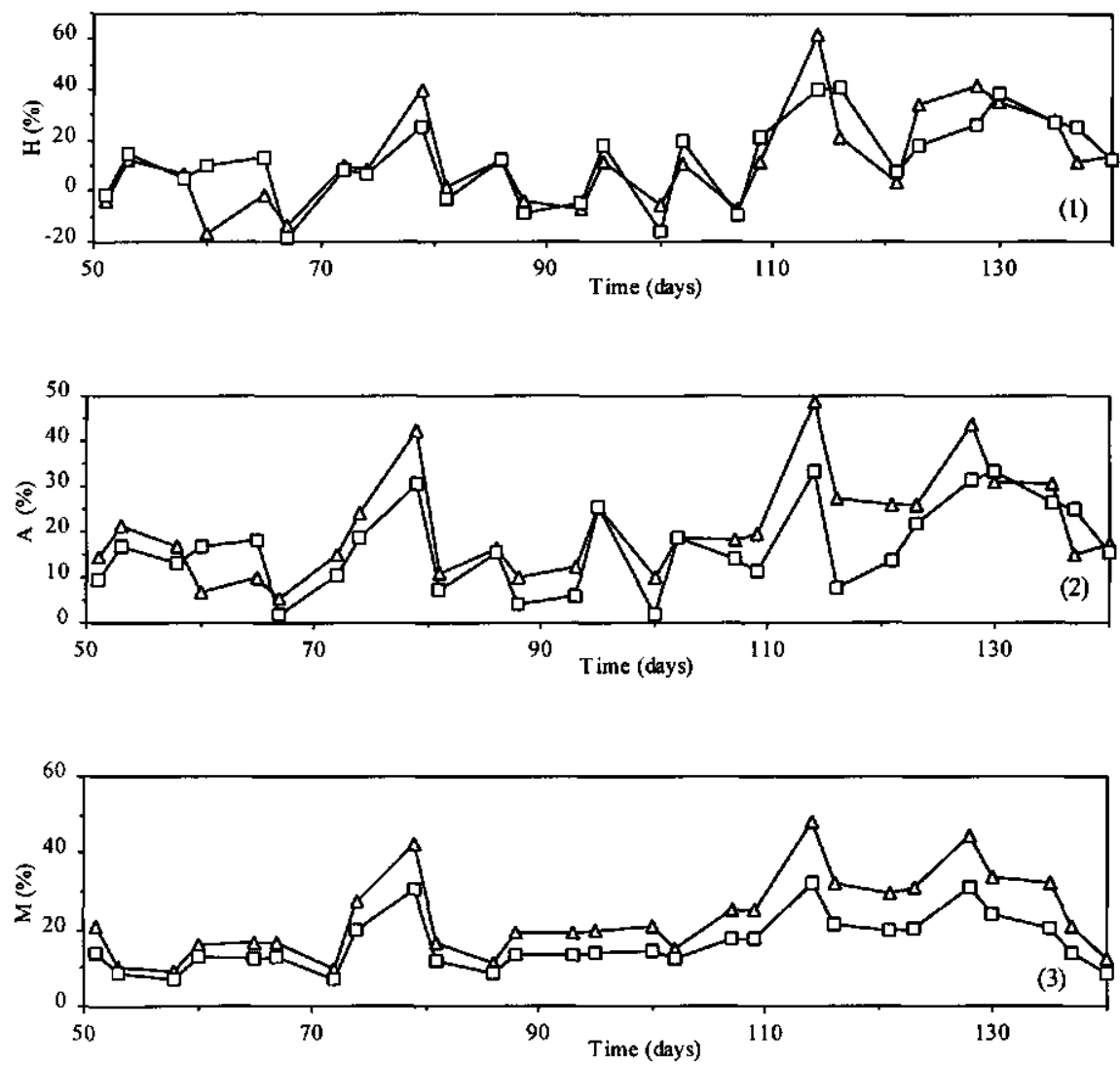

Fig. 3. Percentage of hydrolysis, acidification and methanogenesis of domestic sewage in the $\mathrm{AF}$ and $\mathrm{AH}$ reactors. (1), hydrolysis; (2), acidification; (3), methanogenesis. ( $\Delta$ ), AF reactor; (口), AH reactor.

Table 5. The assessed average values for hydrolysis, acidification and methanogenesis in the $\mathrm{AF}$ and $\mathrm{AH}$ reactor. Standard deviations are presented in brackets

\begin{tabular}{llc}
\hline Parameter & AF reactor & AH reactor \\
\hline $\mathrm{H}(\%)$ & $11.8(18.5)$ & $12.3(16)$ \\
$\mathrm{A}(\%)$ & $20.8(11.1)$ & $16.6(9.4)$ \\
$\mathrm{M}(\%)$ & $23.2(10.6)$ & $16.3(7.1)$ \\
\hline
\end{tabular}

The results demonstrate that hydrolysis, acidification and methanogenesis remain low in both reactors due to the low temperature of $13^{\circ} \mathrm{C}$ and the short HRT of $4 \mathrm{~h}$ and therefore short SRT. Zeeman (1991) and Miron et al. (2000) also found a limited hydrolysis of respectively cow manure and primary sludge at low temperatures. Zeeman (1991) found during 125 days of a batch digestion of cow manure $12,14,18,27$ and $45 \%$ hydrolysis at temperatures of 5,10 , 15,25 and $30^{\circ} \mathrm{C}$ respectively. According to results of Miron et al. (2000) $40 \%$ of SS in the 
primary sludge can be hydrolyzed in a completely mixed reactor at a SRT of $15 \mathrm{~d}$ at a temperature of $25^{\circ} \mathrm{C}$, while at $15^{\circ} \mathrm{C}$ at the same SRT, the hydrolysis only amounted to $4 \%$.

\section{Retained sludge in the reactors and excess sludge}

The attached biomass concentration in the $\mathrm{AF}$ reactor was measured at day 112 by taking two samples of the RPF sheets. After washing with tap water, the biomass concentration in the washed water from each sample was measured. Based on these data, the average biomass concentration in the AF reactor was estimated to be $15.1 \mathrm{gVSS} / 1$. The biomass concentration in the $\mathrm{AH}$ reactor was estimated from the sludge concentration profile and the attached biomass concentration in the RPF sheets in the top of the reactor, measured in a similar way as indicated above. The sludge profile was measured at day 48,93 and 122 and the calculated corresponding total biomass concentration were $13.1,13.9$ and $15.1 \mathrm{gVSS} / 1$ respectively. For the SRT calculations, a sludge concentration of $15 \mathrm{gVSS} / 1$ was used for both reactors.

Fig. 4 and Table 6 show the characteristics of the excess sludge from the reactors. The lower VSS/TSS of the excess sludge from the AH reactor than that from the AF reactor indicates that the first mentioned is better stabilized. This was confirmed by the results of the digestibility tests (Table 6). The excess sludge of both reactors has however a high digestibility and needs therefore post-stabilization. The relatively low SVI and high filterability constant for the excess sludge of the AH reactor as compared to that of the AF reactor, demonstrate that the first is also better settlable and dewaterable. Although the standard deviations found for the mean $\mathrm{SRT}_{\max }$ and $\mathrm{SRT}_{\min }$ of the reactors are high due to the fluctuation of SS in the influent, SRT-values are always higher in the AH reactor as compared to the AF reactor. The higher calculated $\mathrm{SRT}_{\max }$ for the $\mathrm{AH}$ reactor is mainly due to the lower removal efficiency of $\mathrm{COD}_{\mathrm{ss}}$. The higher calculated $\mathrm{SRT}_{\min }$ for the $\mathrm{AH}$ reactor can be attributed to a higher hydrolysis of the entrapped solids in the reactor.

Table 6. Characteristics of the excess sludge from the AF and AH reactor. Standard deviations are presented in brackets

\begin{tabular}{llcc}
\hline Parameter & Unit & AF reactor & AH reactor \\
\hline VSS/TSS & $\%$ & $81.1(3.1)$ & $77.4(3.1)$ \\
SVI & $\mathrm{ml} / \mathrm{gSS}$ & $59.4(9.3)$ & $34.3(2.2)$ \\
Digestibility & $\mathrm{g} \mathrm{CH}_{4}-\mathrm{COD} / \mathrm{g} \mathrm{COD}$ & $0.65(0.03)$ & $0.52(0.03)$ \\
$\chi \times 10^{6}$ & $\mathrm{~kg} \cdot \mathrm{m}^{4} / \mathrm{s}^{2}$ & $28.3(7)$ & $56.2(30.9)$ \\
$\mathrm{SRT}_{\max }$ & $\mathrm{d}$ & $49(31)$ & $144(36)$ \\
$\mathrm{SRT}_{\min }$ & $\mathrm{d}$ & $43(26)$ & $78(24)$ \\
\hline
\end{tabular}

The calculated SRT in the AF and AH reactor, corresponding to minimal 43 and $78 \mathrm{~d}$ and maximal 49 and $144 \mathrm{~d}$ respectively, is in agreement with other results found at treating domestic sewage at low temperatures (Matsushige et al., 1990; Wang, 1994).

\section{General discussion}

The results show a high removal of $\mathrm{COD}_{\mathrm{ss}}$ by using $\mathrm{AF}$ reactor for the pre-treatment of domestic sewage. The performance of the $\mathrm{AF}$ reactor is not only much better than the 
simultaneously tested $\mathrm{AH}$ reactor but also superior to formally published results. While the $A F$ reactor removes $82 \%$ of the $C_{\text {ss }}$, the tested $A H$ reactor removes $53 \%$. Also, the high loaded UASB reactor with HRT $3 \mathrm{~h}$ at $12^{\circ} \mathrm{C}$ tested by Wang (1994) with similar domestic sewage provided only $44 \%$ removal of $\mathrm{COD}_{\mathrm{ss}}$.
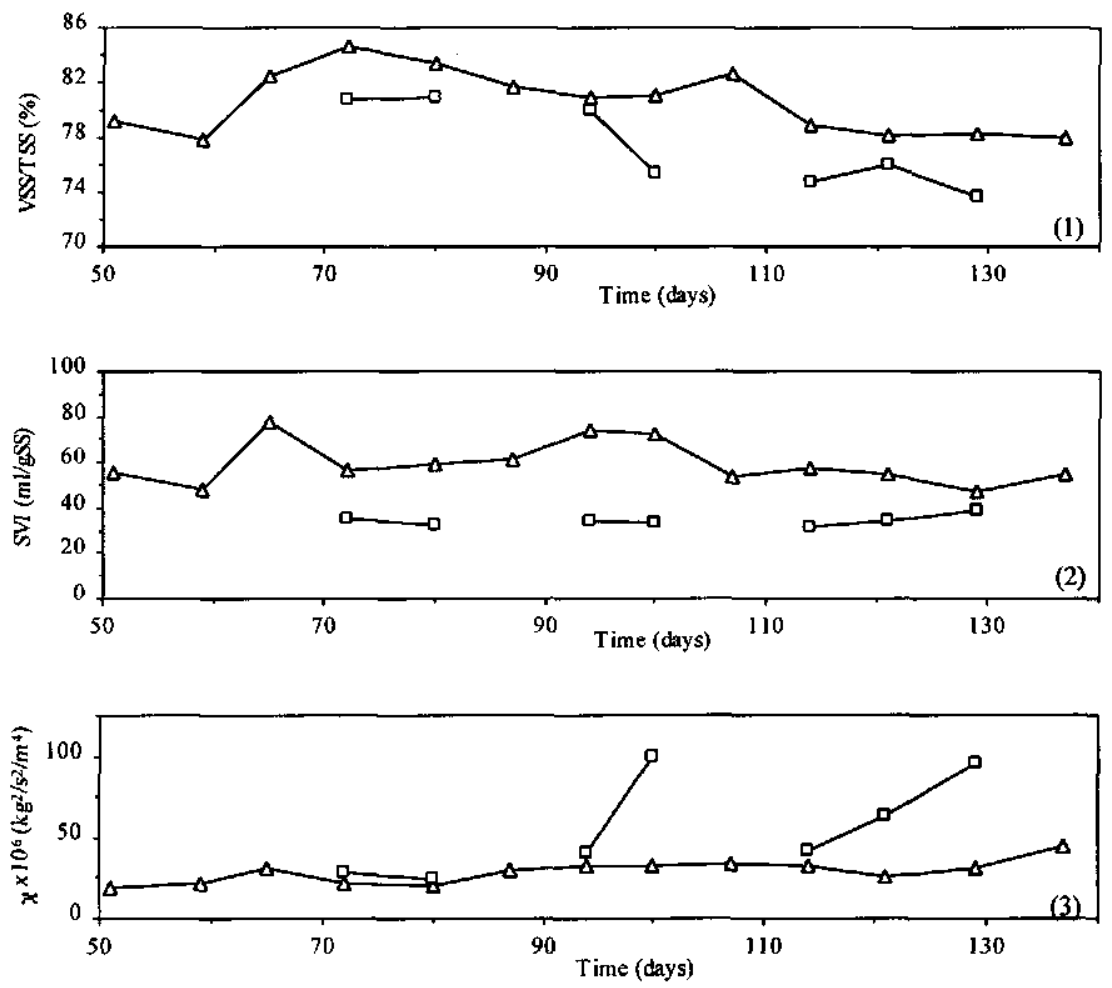

Fig. 4. VSS/TSS, SVI and $\chi$ for the excess sludge from the $\mathrm{AF}$ and $\mathrm{AH}$ reactor. (1), VSS/TSS; (2), SVI; (3), $\chi .(\Delta)$, AF reactor; ( $\square)$, AH reactor.

The high entrapment capacity of the RPF sheets and the discharge of all accumulated SS on the bottom of the reactor were the main reasons for the higher $\mathrm{COD}_{\mathrm{ss}}$ and $\mathrm{COD}_{\mathrm{col}}$ removal in the $\mathrm{AF}$ reactor as compared to the $\mathrm{AH}$ reactor. Elmitwalli et al. (2000) found that clean vertical-sheets of RPF could effectively remove SS from domestic sewage mainly because of its high specific surface area and porosity and moreover, the presence of biofilm improved the biosorption of suspended and colloidal particles. The presence of knobs on the RPF sheets and the vertical orientation of the sheets allow the particles flocs to settle on the bottom of the reactor, where the accumulated sludge can be discharged. Although the discharge of accumulated sludge from the system reduces the total amount of biomass in the reactor, it also prevents clogging of the filter media. However, the RPF sheets could contain attached biomass in a concentration as high as $15 \mathrm{gVSS} / 1$ which is similar to that in the $\mathrm{AH}$ reactor. Moreover, the attached biomass in the AF reactor provides a better contact with wastewater as compared to the suspended sludge biomass in the sludge bed, which contains channels and dead zones especially at low temperatures and low gas production 
(Bolle et al., 1986; Man et al., 1988). Therefore, the AF reactor provides a higher acidification and methanogenesis than the $\mathrm{AH}$ reactor.

The high entrapment of $\mathrm{SS}$ in the $\mathrm{AF}$ reactor as compared to the $\mathrm{AH}$ reactor results in a lower SRT and therefore a lower hydrolysis of the entrapped solids in the AF reactor. This is in agreement with the better sludge characteristics of the AH reactor, with respect to settlability, filtrability and stability. However, also the excess sludge from the AH reactor is not sufficiently stabilized and needs post-stabilization anyway. Therefore, considering the higher $C O D$, removal efficiency, it is recommended to use the AF reactor for the pretreatment of domestic sewage at low temperatures.

The effluent of the AF reactor can be treated in a second anaerobic step for removal of the remaining $\mathrm{COD}_{\text {dis }}$ and $\mathrm{COD}_{\text {col }}$. Elmitwalli et al. (1999) treated pre-settled sewage in an $\mathrm{AH}$ reactor with granular sludge at an HRT of $8 \mathrm{~h}$, at $13^{\circ} \mathrm{C}$ and achieved $52 \%$ and $65 \%$ removal efficiency for $\mathrm{COD}_{\text {dis }}$ and $C O \mathrm{D}_{\text {col }}$ respectively, providing an average effluent $\mathrm{COD}_{\mathrm{t}}$ of 126 $\mathrm{mg} / \mathrm{l}$. As hardly any nutrient are removed during anaerobic treatment, the effluent of the second step (after pathogens removal) represents a valuable product for irrigation and fertilization for regions suffering from a lack of water resources like in the Middle East and for closing water and nutrient cycles. Obviously, the effluent of the AF reactor can also be directly post treated aerobically. In this respect, it is interesting to note that the COD, removal efficiency in the AF reactor is considerably higher than generally found in primary sedimentation tanks and similar to the floating media filter with coagulant addition (Metcalf \& Eddy, 1991; Tanaka et al., 1995). The benefits of optimizing SS removal by using the AF reactor as a pre-treatment step are: an increase in the hydraulic loading, decrease of the organic loading and decrease of the energy consumption in the post treatment process or an increase in treatment capacity of existing systems (Levine et al., 1991; Loosdrecht et al., 1997).

\section{CONCLUSIONS}

Pre-treatment of domestic sewage in an AF reactor results in higher removal efficiencies for $\mathrm{COD}$ fractions than those in the $\mathrm{AH}$ reactor. Mean removal efficiencies in an $\mathrm{AF}$ reactor at $4 \mathrm{~h}$ HRT and $13^{\circ} \mathrm{C}$ are $55,82,35$ and $38 \%$ for respectively $\operatorname{COD}_{t}, \mathrm{COD}_{\mathrm{ss}}, \mathrm{COD}_{\mathrm{col}}$ and $\mathrm{COD}_{\text {dis. }}$.

Although, the $\mathrm{AF}$ reactor shows a better performance for $\mathrm{COD}_{\mathrm{t}}$ removal as compared to the $\mathrm{AH}$ reactor, the excess sludge from the $\mathrm{AH}$ reactor is more stabilized and has a higher settlability and dewaterability. As, the excess sludge from the AH reactor also needs post stabilization, the AF is more suitable for the pre-treatment of domestic sewage at low temperatures.

\section{ACKNOWLEDGEMENTS}

We acknowledge the Egyptian Ministry of Higher Education for the scholarship given for the first author. We are grateful to Recticel, Buren, The Netherlands for providing the 
polyurethane foam sheet. We also are grateful to: W. Sanders, M. Zandvoort, R.E. Roersma, B. Willemsen, D. van Doorn I. Gerrits, J. van der Laan and H. Donker for technical support.

\section{REFERENCES}

Anderson G. K., Kasapgil B. and Ince O. (1994) Comparison of Porous and Non-porous Media in Upflow Anaerobic Filters when Treating Dairy Wastewater. Water Res. 28(7), 1619-1624.

Bolle W. L., Breuge J. van, Eybergen G. C. van, Kossen N. W. F. and Zoetemeyer R. J. (1986) Modelling the liquid flow in up-flow anaerobic sludge blanket reactors. Biotechnol. and Bioeng. 28, 1615-1620.

Dutch Standard Normalized Methods (1969) The Netherlands Normalisation Institute, Delft, The Netherlands.

Elmitwalli T. A., Zandvoort M., Zeeman G., Bruning H. and Lettinga G. (1999) Low temperature treatment of domestic sewage in upflow anaerobic sludge blanket and anaerobic hybrid reactors. Water Sci. Technol. 39(5), 177-185.

Elmitwalli T. A., Dun M. van, Bruning H., Zeeman G. and Lettinga G. (2000) The role of filter media in removing suspended and colloidal particles in anaerobic reactor treating domestic sewage. Biores. Technol. 72(3), 235-242.

Genung R. K., Donaldson T. L. and Reed G. D. (1985) Pilot-scale development of anaerobic filter technology for municipal wastewater treatment. Proc. Seminar/Workshop: Anaerobic Treatment of Sewage, Amherst, MA, pp. 127-160.

Haandel A. C. van and Lettinga G. (1994) Anaerobic Sewage Treatment. John Wiley \& Sons Ltd, England.

Huysman P., Meenen P. van, Assche P. van and Verstraete W. (1983) Factors affecting the colonization of non porous and porous packing materials in model upflow methane reactors. Biotechnol. Lett. 5(9), 643-648.

Imanori Y., Iketani M. and Sudo R. (1983) Effect of temperature on the performance of the anaerobic/aerobic submerged filter system for domestic sewage treatment. J. Sew. Works. Association. 20, 1905-1919.

Jirka A. and Carter M. J. (1975) Micro semi-automated analysis of surface and waste waters for chemical oxygen demand. Analytical Chem. 47, 1397-1401.

Lettinga G., Roersma R. and Grin P. (1983) Anaerobic treatment of raw domestic sewage at ambient temperatures using a granular bed UASB reactor. Biotechnol. and Bioeng. 25, 1701-1723.

Levine A. D., George T. and Asano T. (1991) Size distribution of particulate contaminants wastewater and their impact on treatability. Water Res. 25(8), 922-922.

Lier J. B. van (1995) Thermophilic anaerobic wastewater treatment, temperature aspects and process stability. Ph. D. Thesis, Department of Environmental Technology, Wageningen University, The Netherlands.

Loosdrecht M. C. M., Kuba T., Veldhuizen, H. M van, Brandse F. A. and Heijnen J. J. (1997) Environmental impacts of nutrient removal processes: Case study. J. of Environ. Eng. 123(1), 33-40.

Man A. W. A. de, Grin P. C., Roesma R., Grolle K. C. F. and Lettinga G. (1986) Anaerobic treatment of sewage at low temperatures. Proc. Anaerobic Treatment a Grown-up 
Technology, Amsterdam, The Netherlands, 451-466.

Man A. W. A. de, Last A. R. M. van der and Lettinga G. (1988) The use of EGSB and UASB anaerobic system for low strength soluble and complex wastewaters at temperatures ranging from 8 to $30^{\circ} \mathrm{C}$. Proc. Anaerobic Digestion, Italy, 735-738.

Matsushige K., Inamori Y., Mizuochi M., Hosomi M. and Sudo R. (1990) The effect of temperature on the anaerobic filter treatment for low strength organic wastewater. Environ. Technol. 11, 899-910.

Metcalf \& Eddy Inc. (1991) Wastewater engineering-treatment, disposal, reuse, 3 rd ed., McGraw Hill Inc.

Miron Y., Zeeman G., Lier J. van and Lettinga G. (2000) The role of sludge residence time in the hydrolysis of lipids, carbohydrates and proteins during the anaerobic treatment of domestic sewage. Water Res. 34(5), 1705-1713.

Uemura S. and Harada H. (2000) Treatment of sewage by a UASB reactor under moderate to low temperature conditions. Biores. Technol. 72, 275-282.

Sanz I. and Fdz-Polanco F. (1990) Low temperature treatment of municipal sewage in anaerobic fluidized bed reactors. Water Res. 24(4), 463-469.

Tanaka Y., Miyajima K., Funakosi T. and Chida S. (1995) Filtration of municipal sewage by ring shaped floating plastic net media. Water Res. 29(5), 1387-1392.

Tilche A. and Vieira S. M. M. (1991) Discussion report on reactor design of anaerobic filters and sludge bed reactors. Water Sci. Technol. 24(8), 193-206.

Vesilind P. A. (1988) Capillary suction time as a fundamental measure of sludge dewaterability. J. Water Pollut. Control Fed. 60(2), 215-220.

Wang K. (1994) Integrated anaerobic and aerobic treatment of sewage. $\mathrm{Ph}$. D. thesis, Department of Environmental Technology, Wageningen University, The Netherlands.

Young J. C. (1991) Factors affecting the design and performance of upflow anaerobic filters. Water Sci. Technol. 24(8), 133-155

Zeeman G. (1991) Mesophilic and psychrolphilic digestion of liquid manure. Ph. D. Thesis, Department of Environmental Technology, Wageningen University, The Netherlands.

Zeeman G., Sanders W. T. M., Wang K. Y and Lettinga G. (1997) Anaerobic treatment of complex wastewater and waste activated sludge. Application of upflow anaerobic solid removal (UASR) reactor for the removal and pre-hydrolysis of suspended COD. Water Sci. Technol. 35(10), 121-128.

Zeeman G. and Lettinga G. (1999) The Role of anaerobic digestion of domestic sewage in closing the water and nutrient cycle at community level. Water Sci. Technol. 39(5), 187-194.

Zeeuw W. J. de (1984) Acclimatization of anaerobic sludge for UASB reactor start-up. Ph. D. thesis, Department of Environmental Technology, Wageningen University, The Netherlands. 


\section{Chapter 6}

\section{TREATMENT OF DOMESTIC SEWAGE IN A TWO- STEP SYSTEM ANAEROBIC FILTERIANAEROBIC HYBRID REACTOR AT LOW TEMPERATURE}

Submitted as:

Elmitwalli T. A., Oanh K. L. T., Zeeman G. and Lettinga G. (submitted) treatment of domestic sewage in a two-step system anaerobic filter/anaerobic hybrid reactor at low temperature. Water Res. 


\title{
TREATMENT OF DOMESTIC SEWAGE IN A TWO-STEP SYSTEM ANAEROBIC FILTERIANAEROBIC HYBRID REACTOR AT LOW TEMPERATURE
}

\begin{abstract}
The treatment of domestic sewage at low temperature of $13^{\circ} \mathrm{C}$ was investigated in a twostep system consisting of an anaerobic filter (AF) + an anaerobic hybrid (AH) reactor operated at different HRTs. The AF reactor was efficient in the removal of suspended COD, viz. 81,58 and $57 \%$ at HRT of respectively 4,2 and $3 \mathrm{~h}$. For optimization of the removal of suspended COD and dissolved COD, an HRT of $4+4 \mathrm{~h}$ is required for the AF+AH system. This also prevents deterioration of the methanogenic activity of granular sludge in the $\mathrm{AH}$ reactor. For additional optimization of colloidal COD removal, the $\mathrm{AH}$ reactor needs an HRT of $8 \mathrm{~h}$. The AF+AH system operated at an HRT of $4+8 \mathrm{~h}$ at $13^{\circ} \mathrm{C}$ provided a high removal efficiency for all COD fractions. The achieved total COD removal was as high as $71 \%$ which is similar to values found in tropical areas. Moreover, $60 \%$ of the removed $\mathrm{COD}$ was converted to methane.
\end{abstract}

\section{KEYWORDS}

Wastewater treatment; domestic sewage; anaerobic digestion; anaerobic filter; anaerobic hybrid; polyurethane foam.

\section{INTRODUCTION}

High-rate anaerobic treatment is an attractive process for domestic sewage because of its low construction, operation and maintenance costs, small land requirement, low excess sludge production and production of biogas. Although the anaerobic treatment of domestic sewage has been applied at large scale in several tropical countries, the process so far is not applied at full scale in countries with lower temperatures. This mainly due to lower removal efficiencies. Also, at low temperatures, a longer hydraulic retention time (HRT) is needed due to the lower rate of hydrolysis (Man et al., 1986) and the higher amount of accumulating suspended solids (SS) at decreasing temperature (Zeeman and Lettinga, 1999).

Upflow anaerobic sludge blanket (UASB) reactors inoculated with granular sludge give a better performance than reactors inoculated with flocculant sludge (Lettinga et al., 1983). However, when treating domestic sewage in granular sludge UASB reactors at low temperatures, accumulation of SS occurs in the granular sludge bed, which leads to deterioration of the overall methanogenic activity and the reactor performance (Man et al., 1986; Uemura and Harada, 2000). Several investigators (Last and Lettinga, 1992; Wang, 1994; Zeeman et al., 1997; Zeeman and Lettinga, 1999; Elmitwalli et al., 1999 a; Kalogo and Verstraete W, 1999; Elmitwalli et al., 2000) revealed that at low temperatures pre-removal of SS is needed prior to anaerobic treatment in granular sludge bed reactors. Wang (1994) developed a two-step system, UASB+EGSB (expanded granular sludge bed) reactor, for the 
treatment of domestic sewage at low temperatures. The first step is aimed at removal and partial hydrolysis of suspended $\mathrm{COD}\left(\mathrm{COD}_{\mathrm{ss}}\right)$ and the second step mainly for conversion of dissolved $\mathrm{COD}\left(\mathrm{COD}_{\mathrm{dis}}\right)$ to methane. However, it turned out that the removal of colloidal $\mathrm{COD}\left(\mathrm{COD}_{\mathrm{col}}\right)$ was limited in this combined UASB+EGSB system.

Recently, Elmitwalli et al. (1999 b) showed that the use of an AH reactor (i.e. addition of filter medium instead of a gas solids separator and settler in the classical UASB reactor) with flocculant sludge bed for the pre-removal of SS did not significantly improve the removal efficiency as compared to that in a normal UASB reactor operated by Wang (1994). By using an $\mathrm{AF}$, however, higher removal efficiency is achieved for $\mathrm{COD}_{\mathrm{ss}}(\mathrm{viz}$. 82\%). In this $\mathrm{AF}$ reactor vertical sheets of reticulated polyurethane foam (RPF) with knobs were applied as packing material. A sludge bed was not allowed to develop in the reactor. So, all biomass retained in the reactor was attached to the RPF sheets. The vertical orientation of the sheets and the presence of knobs and biomass (in attached form) efficiently prevented clogging of the filter during an operational period of 140 days at HRT of $4 \mathrm{~h}$ at $13^{\circ} \mathrm{C}$.

Elmitwalli et al. (1999 a) compared between a UASB and an AH reactor with a granular sludge bed both at $8 \mathrm{~h} \mathrm{HRT}$ for the treatment of pre-settled sewage at a temperature of $13^{\circ} \mathrm{C}$. The media used in the AH reactor consisted of vertical RPF sheets with knobs. At 'steady state', the $\mathrm{AH}$ reactor removed $64 \%$ of the total $\mathrm{COD}\left(\mathrm{COD}_{1}\right)$, which was significantly higher by $4 \%$ than the efficiency obtained in the UASB reactor.

Based on these results, the use of an AF reactor with vertical sheets of RPF with knobs as a first step followed by an $\mathrm{AH}$ reactor with a granular sludge bed, was considered as an appropriate process configuration for the anaerobic treatment of raw domestic sewage at low temperatures. The objective of the present research is to assess the performance of such a twostep $(\mathrm{AF}+\mathrm{AH})$ system for the treatment of domestic sewage at a temperature of $13^{\circ} \mathrm{C}$.

\section{MATERIALS AND METHODS}

\section{Experimental set-up}

Fig. 1 shows a schematic diagram of the experimental set-up, consisting of an AF reactor (60 1) and an $\mathrm{AH}$ reactor $(651)$, both manufactured from plexiglas and connected in series. The diameter of both reactors was $0.19 \mathrm{~m}$ and the heights of the AF and $\mathrm{AH}$ reactor were 2.1 and $2.3 \mathrm{~m}$ respectively. The media used in the reactors were vertical sheets of RPF with knobs at one side (Recticel, Buren, The Netherlands). The media in the AF reactor (type Filteren TM10) were oriented vertically, face to back, without spacing. The medium used in the AH reactor consisted of a $1 \mathrm{~m} \times 1.5 \mathrm{~m}$ sheet (type Filteren TM30) moulded in a cylindrical shape. The cylinder of RPF with a height of $1 \mathrm{~m}$ was oriented vertically in the top of the AH reactor above the gas-solids separator. The characteristics of the used RPF sheets are presented in Table 1. The temperature in the reactors was controlled at $13^{\circ} \mathrm{C}$ by recirculating thermostated water of $13^{\circ} \mathrm{C}$ through a tube placed around the reactors.

The experiments were started with clean media. The $\mathrm{AH}$ reactor was inoculated with granular sludge originating from a UASB reactor treating activated sludge filtrate from the 'Zimpro 
process', Breda, The Netherlands. The maximum specific methanogenic activity $\left(\mathrm{SMA}_{\max }\right.$ ) for the inoculum sludge amounted to $0.34 \mathrm{~kg}$ COD.kg ${ }^{-1} \mathrm{VSS} . \mathrm{d}^{-1}$ at $30^{\circ} \mathrm{C}$. The $\mathrm{AF}+\mathrm{AH}$ system was operated for 294 days, 144, 81 and 69 days at HRTs of respectively $4+8,2+4$ and $3+6 \mathrm{~h}$. The first 50 days of operation were considered as a start-up period, while the periods from day 144-166 and 225-251 were considered as acclimatisation periods to the new HRT. Accumulated sludge on the bottom of the AF reactor was wasted three times per week when operated at an HRT of 2 and $3 \mathrm{~h}$ and once per week when operated at an HRT of $4 \mathrm{~h}$. The sludge bed in the AH reactor was controlled at a height of $1 \mathrm{~m}$ by wasting the excess sludge from the top of the sludge bed.



Fig. 1. Schematic diagram of the experimental set-up. 1, influent; 2, peristaltic pump; 3, $\mathrm{AF}$ reactor; 4, media of the AF reactor (vertical sheets of RPF, type TM10); 5, gasmeter; 6 , effluent of the AF reactor; 7, AH reactor; 8, granular sludge bed; 9, gas-solids separator; 10 , media of the AH reactor (vertical sheet of RPF type TM30); 11, effluent of the AH reactor.

Table 1. The characteristics of the RPF sheets used in the experiment.

\begin{tabular}{lccc}
\hline Parameter & Unit & AF media & AH media \\
\hline Total sheet thickness & $\mathrm{mm}$ & 25 & 25 \\
Knob thickness & $\mathrm{mm}$ & 15 & 15 \\
Number of pores & pore/inch & $7-15$ & $25-35$ \\
\hline
\end{tabular}




\section{Wastewater}

The system was fed with domestic sewage originating from the village Bennekom, The Netherlands. The sewage is collected in a combined sewer system. Table 2 summarizes the main characteristics of the sewage. Weekly, three composite samples ( 2 samples of $48 \mathrm{~h}$ and one sample of $72 \mathrm{~h}$ ) from the raw sewage, the effluent of the $\mathrm{AF}$ reactor and the effluent of the $\mathrm{AH}$ reactor were collected in containers placed in a refrigerator at $4^{\circ} \mathrm{C}$.

\section{Analytical Methods}

COD was assessed using the micro-method described by Jirka and Carter (1975). Raw samples were used for $\mathrm{COD}_{1}, 4.4 \mu \mathrm{m}$ folded paper-filtered (Schleicher \& Schuell 5951/2) samples for $\mathrm{COD}_{\mathrm{f}}$ and $0.45 \mu \mathrm{m}$ membrane-filtered (Schleicher \& Schuell ME 25) samples for $\mathrm{COD}_{\mathrm{dis}}$. The $\mathrm{COD}_{\mathrm{ss}}$ and $\mathrm{COD}_{\mathrm{col}}$ were calculated by the differences between $\mathrm{COD}_{\mathrm{t}}$ and $\mathrm{COD}_{\mathrm{f}}$, $\mathrm{COD}_{\mathrm{f}}$ and $\mathrm{COD}_{\mathrm{dis}}$ respectively. Volatile fatty acids (VFA) were measured from membranefiltered samples with a gas chromatograph, as described by Lier (1995). The biogas composition $\mathrm{CH}_{4}, \mathrm{CO}_{2}, \mathrm{~N}_{2}$ and $\mathrm{O}_{2}$ was determined in a $100 \mu \mathrm{l}$ sample using a gas chromatograph, described by Lier (1995). The Kjeldahl nitrogen (Kj-N), sludge volume index (SVI), capillary suction time (CST), total solids (TS), SS and volatile suspended solids (VSS) were measured according to the Dutch Standard Normalized Methods (1969). Proteins and carbohydrates (measured for raw, paper-filtered and membrane-filtered samples) were analysed according to the method described by Miron et al. (2000). E-coli (measured for raw and paper-filtered samples) was analysed according to Havelaar and During (1988). Total $\mathrm{PO}_{4}-\mathrm{P}$ for wastewater was measured with an auto analyser (Skalar) after treatment according to the Dutch Standard Normalized Methods (1969), while $\mathrm{NH}_{4}^{+}-\mathrm{N}$ and dissolved $\mathrm{PO}_{4}{ }^{3}-\mathrm{P}$ were directly measured with the same auto analyser. $\mathrm{SMA}_{\max }$ was measured at $30^{\circ} \mathrm{C}$ according to Lier (1995) by acetate depletion in the second feed with an initial acetate concentration of about $1.5 \mathrm{gCOD} / 1$ for each feed and a sludge concentration of about $2 \mathrm{gVSS} / 1$. Sludge digestibility was performed as described by Lier (1995) for a period of 60 days.

For all excess sludge samples from the AF reactor the volume and the SS and VSS concentration were measured. When the AF reactor was operated at an HRT of 2 and $3 \mathrm{~h}$, additionally 5 samples were analysed for SVI, CST and TS. The sludge digestibility was measured twice and in duplicate for the excess sludge from the AF reactor when operated at an HRT of $2 \mathrm{~h}$. The excess sludge of the AH reactor was analysed for its SS and VSS content. The $\mathrm{SMA}_{\max }$ of the excess sludge of the AF reactor and a composite sample of the granular sludge present in the $\mathrm{AH}$ reactor, was analysed after each acclimatisation period and at the end of each HRT. The SMA $\mathrm{max}_{\max }$ was also measured for the attached sludge in the AF and in the AH reactor at the end of each HRT. The attached sludge in the AF and AH reactor was separated as mentioned by Elmitwalli et al. (1999 b).

\section{Calculations}

The percentage of hydrolysis $(\mathrm{H})$, acidification $(\mathrm{A})$ and methanogenesis $(\mathrm{M})$, the maximum $\left(\mathrm{SRT}_{\max }\right)$ and minimum sludge residence time $\left(\mathrm{SRT}_{\min }\right)$ and the filterability constant $(\chi)$ were calculated as described by Elmitwalli et al. $(1999 \mathrm{~b})$. The amount of dissolved methane in the effluent was calculated according to Henry's Law. Statistical comparison of the performance 


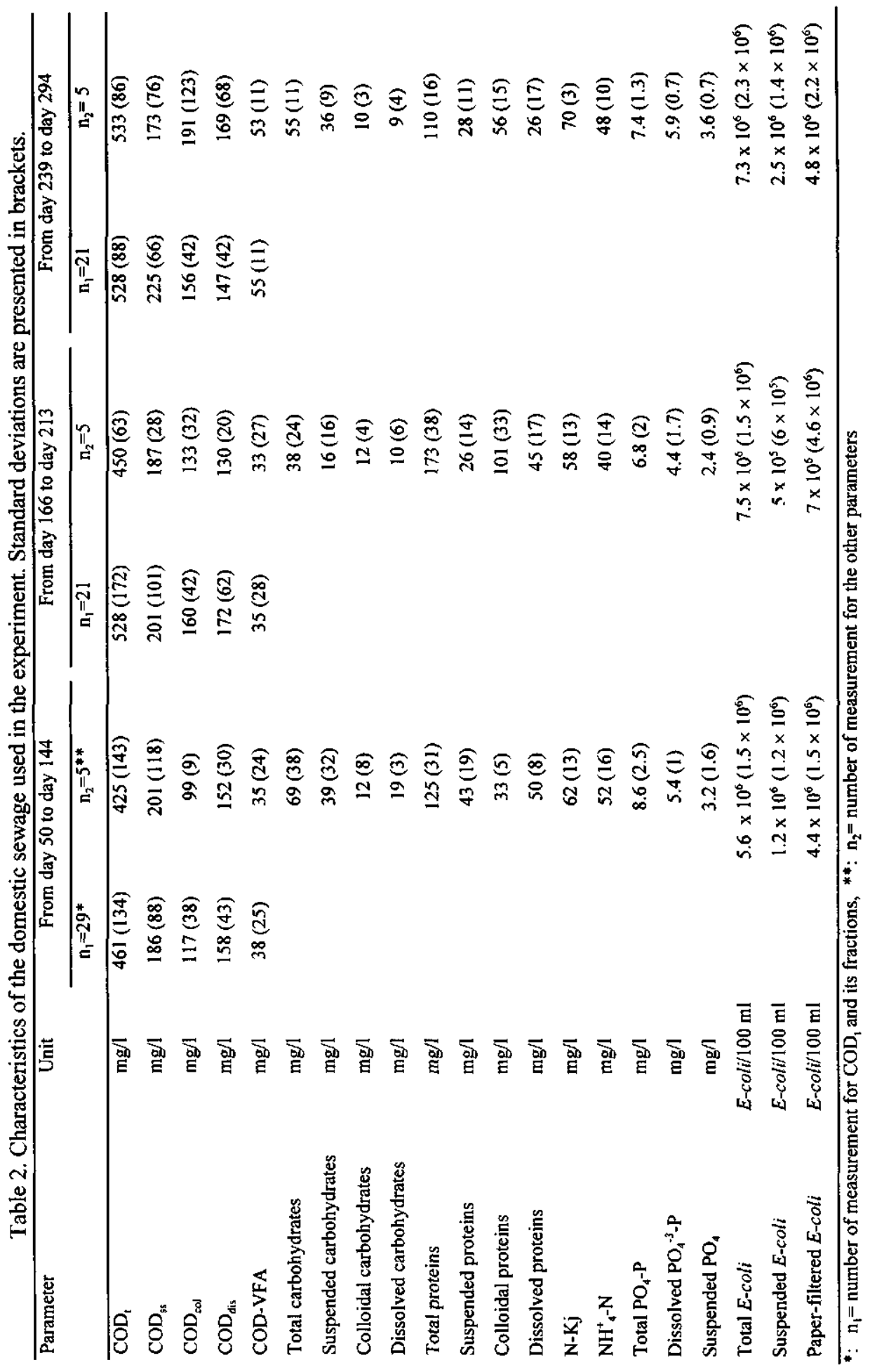


of the reactors between different HRTs was done as described by Elmitwalli et al. (1999 b).

\section{RESULTS AND DISCUSSION}

\section{COD and VFA removal}

The results in Fig. 2-1 show the effect of the HRT on the removal of $\mathrm{COD}_{t}$ and the distinguished COD fractions in the AF reactor. The results indicate that increasing the HRT from 2 to $4 \mathrm{~h}$ significantly (level $10 \%$ ) improves the $\mathrm{COD}_{1}$ removal mainly as a result of a higher $\mathrm{COD}_{\mathrm{ss}}$ removal. At an HRT of $4 \mathrm{~h}$, the AF reactor removes $81 \%$ of $\mathrm{COD}_{\mathrm{ss}}$ which is significantly higher (level $0.01 \%$ ) than that at HRT of $3 \mathrm{~h}$. However, the removal of $\mathrm{COD}_{\mathrm{ss}}$ does not significantly decline when decreasing the HRT from $3 \mathrm{~h}$ to $2 \mathrm{~h}$. At an HRT of $2 \mathrm{~h}$, the $\mathrm{AF}$ reactor removes $58 \%$ of the $\mathrm{COD}_{\mathrm{ss}}$, which is distinctly higher than achieved in the UASB reactor (44\%) operated by Wang (1994) at an HRT of $3 \mathrm{~h}$ at $12^{\circ} \mathrm{C}$. The removal efficiencies of both $\mathrm{COD}_{\mathrm{col}}$ and $\mathrm{COD}_{\mathrm{dis}}$ are limited in the AF reactor at these HRTs.
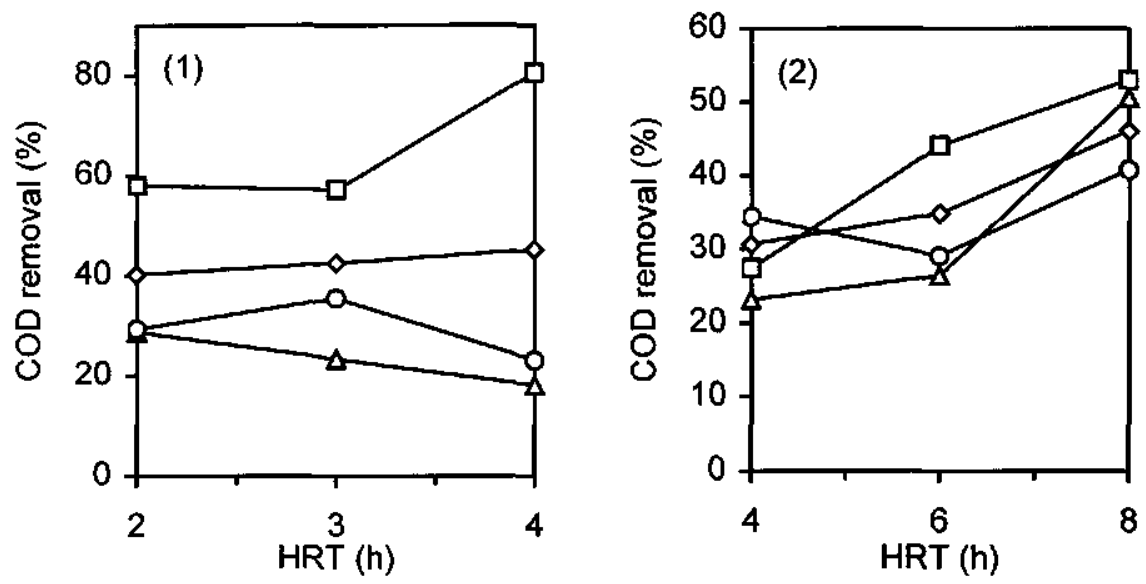

Fig. 2. Effect of HRT on the removal of $\mathrm{COD}_{1}$ and its fractions during the treatment of domestic sewage in the $\mathrm{AF}$ and $\mathrm{AH}$ reactor at $13^{\circ} \mathrm{C}$. (1), $\mathrm{AF}$ reactor; (2), $\mathrm{AH}$ reactor. $(\vartheta)$, $\mathrm{COD}_{i} ;(\square), \mathrm{COD}_{\mathrm{ss}} ;(\triangle), \mathrm{COD}_{\mathrm{sol}} ;(\mathrm{O}), \mathrm{COD}_{\mathrm{dis}}$.

The results in Fig. 2.2 show that the removal efficiencies for $\mathrm{COD}_{t}, \mathrm{COD}_{\mathrm{col}}$ and $\mathrm{COD}_{\mathrm{dis}}$ in the $\mathrm{AH}$ reactor significantly improve at increasing the HRT from 6 to $8 \mathrm{~h}$ (level $0.1,0.05$ and $1 \%$ respectively), while increasing the HRT from 4 to $6 \mathrm{~h}$ only significantly (level $5 \%$ ) improves the removal efficiency of $\mathrm{COD}_{\mathrm{ss}}$.

Table 3 summarizes the removal efficiencies for $\mathrm{COD}_{1}$, the distinguished $\mathrm{COD}$ fractions and VFA during the treatment of the sewage in the $A F+A H$ system. The removal efficiencies for $\mathrm{COD}_{t}, \mathrm{COD}_{\mathrm{ss}}$ and $\mathrm{COD}_{\mathrm{col}}$ are significantly higher in the $\mathrm{AF}+\mathrm{AH}$ system operated at an HRT of $4+8 \mathrm{~h}$ as compared to those at an HRT of $3+6 \mathrm{~h}$ (level $0.1,0.01$ and $5 \%$ respectively), while only the removal of $\mathrm{COD}_{\mathrm{t}}$ and $\mathrm{COD}_{\mathrm{ss}}$ at an HRT of $3+6 \mathrm{~h}$ is significantly higher (level 10 and $10 \%$ respectively) as compared to that an HRT of $2+4$ 
h. The results clearly show that the removal efficiencies for $\operatorname{COD}_{\text {dis }}$ are similar $(54-55 \%)$ under different $\mathrm{HRT}$ imposed to the $\mathrm{AF}+\mathrm{AH}$ system as a result of the presence of a high content of active granular sludge in the $\mathrm{AH}$ reactor. This indicates that, in terms of $\mathrm{COD}_{\text {dis, }}$, the system is still under loaded, even at an HRT of $2+4 \mathrm{~h}$. The removal efficiency for $\mathrm{COD}_{\text {dis }}$ in the $\mathrm{AF}+\mathrm{AH}$ system is equal to the maximum removal $(54 \%)$ achieved in a batch recirculation experiment with the same type of sewage (Last and Lettinga, 1992). The removal of $\mathrm{COD}_{\mathrm{t}}$ in the $\mathrm{AF}+\mathrm{AH}$ system at an $\mathrm{HRT}$ of $4+8 \mathrm{~h}$ exceeds that found in other investigations at similar temperature (Grin et al., 1983; Man et al., 1986; Wang, 1994). The higher removal of $\mathrm{COD}_{\mathrm{t}}$ found in the $\mathrm{AF}+\mathrm{AH}$ system can be attributed to the improved removal of $C O D_{s s}$ in the $A F$ reactor and an improved removal of the $C O D_{\text {col }}$ and $C O D_{\text {dis }}$ in the second step. Additional to the effect of the granular sludge, the presence of the RPF media at the top of the $\mathrm{AH}$ reactor enhances in entrapment of $\mathrm{COD}_{\text {col }}$ as shown by Elmitwalli et al. (1999 a)

Table 3. $\mathrm{COD}_{t}, \mathrm{COD}$ fractions and VFA removal efficiencies (\%) in the $\mathrm{AF}+\mathrm{AH}$ system at imposed different HRTs. Standard deviations are presented in brackets.

\begin{tabular}{lccc}
\hline & $4+8 \mathrm{~h}$ & $2+4 \mathrm{~h}$ & $3+6 \mathrm{~h}$ \\
\hline $\mathrm{COD}_{\mathrm{t}}$ & $70.6(7.4)$ & $58.6(7.7)$ & $63(7.4)$ \\
$\mathrm{COD}_{\mathrm{ss}}$ & $91.3(8.4)$ & $70.5(16.4)$ & $78.8(7.4)$ \\
$\mathrm{COD}_{\mathrm{col}}$ & $59.6(14.7)$ & $45.3(17.1)$ & $45.8(18.5)$ \\
$\mathrm{COD}_{\text {dis }}$ & $55.2(14.3)$ & $54.8(15.2)$ & $53.6(10)$ \\
VFA-COD & $97(4.4)$ & $77.9(22.7)$ & $91.3(4)$ \\
\hline
\end{tabular}

\section{Carbohydrates, proteins, nutrient and E-coli removal}

As no significant difference was found in the removal of carbohydrates, proteins, nutrient and $E$-coli in the AF+AH system between different HRTs, only the results obtained at an HRT of $4+8 \mathrm{~h}$ are summarized in Table 4 . The AF+AH system is efficient in removing carbohydrates, apparently mainly as a result of the high removal efficiency for suspended carbohydrates and it exceeds the removal of proteins. The removal of suspended proteins is clearly substantially higher than those for the other proteins fractions. The results also demonstrate that most of the $E$-coli in the sewage are associated with colloidal particles. The removal efficiency for $E$-coli remained restricted under all operational conditions. As the $\mathrm{AF}+\mathrm{AH}$ system shows a high removal efficiency for $\mathrm{COD}_{\mathrm{ss}}$, the system also eliminates most of the E-coli are associated with suspended particles and the effluent mainly contains $E$-coli associated with colloidal particles. Furthermore, the results reveal an efficient removal of suspended phosphate and a release of dissolved phosphate. The system removes part of the Kjeldahl nitrogen due to SS removal, but $\mathrm{NH}_{4}^{+}{ }_{4} \mathrm{~N}$ is released as a result of hydrolysis of proteins.

\section{Characteristics of the retained sludge in the reactors and excess sludge}

The results in Table 5 show the characteristics of the retained and the excess sludge of both reactors. The SVI of the excess sludge from the AF reactor drops with decreasing HRT. A higher level of partial hydrolysis, resulting in smaller particles, might be the reason for the poorer settlability at longer HRTs. However, the SVI of the excess sludge produced in the AF reactor under different HRTs is always $<60 \mathrm{ml} / \mathrm{gSS}$, which indicates a relatively good 
settlability. The filterability constant of the excess sludge from the AF reactor is similar at different HRTs, similar to that of well digested primary sludge and exceeds that of raw primary sludge (Miron et al., 2000).

Table 4. Carbohydrates, proteins, $E-c o l i, \mathrm{PO}_{4}-\mathrm{P}, \mathrm{Kj}-\mathrm{N}$ and $\mathrm{NH}_{4}^{+}-\mathrm{N}$ removal efficienies (\%) in the $\mathrm{AF}+\mathrm{AH}$ system at imposed HRT of $4+8 \mathrm{~h}$. Standard deviations are presented in brackets.

\begin{tabular}{llccc}
\hline Parameter & & $\mathrm{AF}$ & $\mathrm{AH}$ & $\mathrm{AF}+\mathrm{AH}$ \\
\hline Carbohydrates & Total & $75(5)$ & $20(8)$ & $80(5)$ \\
& Suspended & $94(4)$ & $39(57)$ & $97(1)$ \\
& Colloidal & $75(7)$ & $-10(17)$ & $65(8)$ \\
& Dissolved & $18(15)$ & $23(16)$ & $39(4)$ \\
Protein & Total & $33.1(7.1)$ & $33.7(6.4)$ & $55.6(6.8)$ \\
& Suspended & $66.4(7.3)$ & $33.3(47.1)$ & $78.3(14.9)$ \\
& Colloidal & $6.3(12.5)$ & $25(16.7)$ & $31.3(4.2)$ \\
& Dissolved & $24.6(17.5)$ & $39.2(7.9)$ & $54.2(11.7)$ \\
$E$-coli & Total & $20.3(26.7)$ & $12(40.7)$ & $32.8(28.5)$ \\
& Suspended & $75.3(29.5)$ & $100(0)$ & $100(0)$ \\
& Paper-filtered & $22.1(19.1)$ & $-3.2(43.3)$ & $21.4(30.5)$ \\
$\mathrm{PO}_{4}-\mathrm{P}$ & Total & $15.5(8.2)$ & $0.6(5.5)$ & $16(8.9)$ \\
& Suspended & $38.5(26.5)$ & $39.3(31.5)$ & $64.8(21.3)$ \\
& Dissolved & $1.7(8.9)$ & $-13.6(11.9)$ & $-11.5(12.8)$ \\
$\mathrm{Kj}^{-\mathrm{N}}$ & & $6.2(5.2)$ & $-1.4(6.2)$ & $4.9(8.3)$ \\
$\mathrm{NH}_{4}^{+}-\mathrm{N}$ & & $-0.3(11.7)$ & $-7(1.9)$ & $-7.3(13.6)$ \\
\hline
\end{tabular}

The amount of excess sludge produced in the $\mathrm{AF}+\mathrm{AH}$ system mainly originates from the AF reactor. The excess sludge production in the AF reactor amounts to $20-35 \%$ of the removed $\mathrm{COD}_{\mathrm{t}}$ in the $\mathrm{AF}+\mathrm{AH}$ system, while the excess sludge production in the $\mathrm{AH}$ reactor only amounts to $0.5-1.5 \%$. The digestibility results and the values found for the VSS/SS ratio indicate that the excess sludge from the AF reactor is not well stabilized and still needs post stabilization. However, the excess sludge from the $\mathrm{AH}$ reactor is well stabilized as the VSS/SS ratio of the excess sludge was as low as 0.63 .

Values calculated for $\mathrm{SRT}_{\max }$ and $\mathrm{SRT}_{\min }$ for the AF reactor significantly (respectively level 10 and $0.01 \%$ ) increase at longer HRT from 3 to $4 \mathrm{~h}$. The high values for $\mathrm{SRT}_{\max }$ and $\mathrm{SRT}_{\text {tmin }}$ in the $\mathrm{AH}$ reactor indicate that the hydrolysis, acidification and methanogenesis can proceed sufficiently. At low temperatures, the SRT should exceed 100 days in order to retain sufficient activity in the anaerobic reactor (Zeeman and Lettinga, 1999).

The $\mathrm{SMA}_{\max }$ of the attached sludge in both reactors, of the excess sludge from the $\mathrm{AF}$ reactor and of the granular sludge in the $\mathrm{AH}$ reactor is summarized in Table 6 . The results clearly show that the $\mathrm{SMA}_{\max }$ of the attached and excess sludge of the AF reactor remains low at the imposed HRTs. In fact, mainly removal and partial hydrolysis of SS proceed in

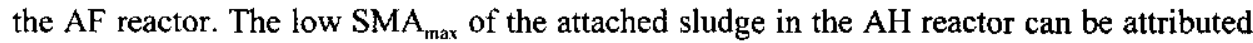
to the low organic loading of biodegradable COD imposed to attached biomass, as most of this COD has already consumed in the granular sludge bed. As the previously found by Elmitwalli et al. (1999 a), the presence of vertical sheets of RPF in the AH reactor does not 
significantly improve the $\mathrm{COD}_{\mathrm{dis}}$ removal, but significantly improves the $\mathrm{COD}_{\mathrm{col}}$ removal.

The $\mathrm{SMA}_{\max }$ found for the granular sludge in the AH reactor operated at an HRT of $4 \mathrm{~h}$ was significantly lower than that at an HRT of $8 \mathrm{~h}$. However, the SMA $\mathrm{max}_{\max }$ recovered after operating the reactor at an HRT of $6 \mathrm{~h}$. The deterioration for the SMA max $_{\text {ax }}$ of the granular sludge in the AH reactor at an HRT of $4 \mathrm{~h}$ results from the high SS load (Fig. 3), which leads to attachment and adsorption of slowly biodegradable organic particles to the granular sludge and accordingly to a decrease in its activity due to substrate limitation (Alphenaar, 1994). Therefore, the $\mathrm{COD}_{\mathrm{ss}}$ loading for the $\mathrm{AH}$ reactor should be lower than $0.38 \mathrm{~kg}$ $\mathrm{COD}_{\mathrm{ss}} \cdot \mathrm{m}^{-3} \cdot \mathrm{d}^{-1}$, the loading applied at an HRT of $6 \mathrm{~h}$. The deterioration of the SMA $\mathrm{A}_{\max }$ for the granular sludge in the AH reactor at an HRT of $4 \mathrm{~h}$ confirms the importance of SS separation in the first step prior to the treatment of domestic sewage in the methanogenic reactor.

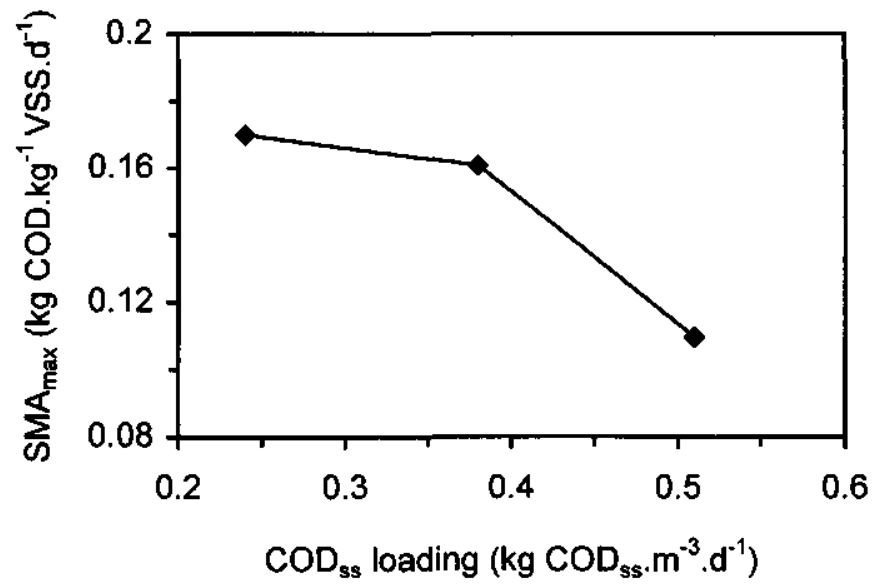

Fig. 3. Effect of $\mathrm{COD}_{\mathrm{ss}}$ loading on the $\mathrm{SMA}_{\max }$ at $30^{\circ} \mathrm{C}$ for the granular sludge in the $\mathrm{AH}$ reactor.

\section{Hydrolysis, acidification and methanogenesis}

The results show that the $\mathrm{CH}_{4}$ content in the biogas is high (72-82\%) and comparable to values reported by Lettinga et al. (1983), Draaijer et al. (1992) and Schellinkhout and Osario (1992). Table 7 provides values calculated for the hydrolysis, acidification and methanogenesis in the $\mathrm{AF}+\mathrm{AH}$ system. Due to considerable fluctuations in the domestic sewage concentration and composition, no significant difference is found for the hydrolysis, acidification and methanogensis in the $\mathrm{AF}$ reactor, $\mathrm{AH}$ reactor and $\mathrm{AF}+\mathrm{AH}$ system between the imposed different HRTs. However, the high SRT prevailing in the AH reactor at different HRTs guarantees relatively high hydrolysis, acidification and methanogenesis in this reactor.

The value found for hydrolysis and methanogenesis based on the amount of removed COD in the $\mathrm{AF}+\mathrm{AH}$ system at different HRTs range from $47-64 \%$ and $60-74 \%$ respectively. Those values are distinctly higher than those found by Uemura and Harada (2000), viz. 


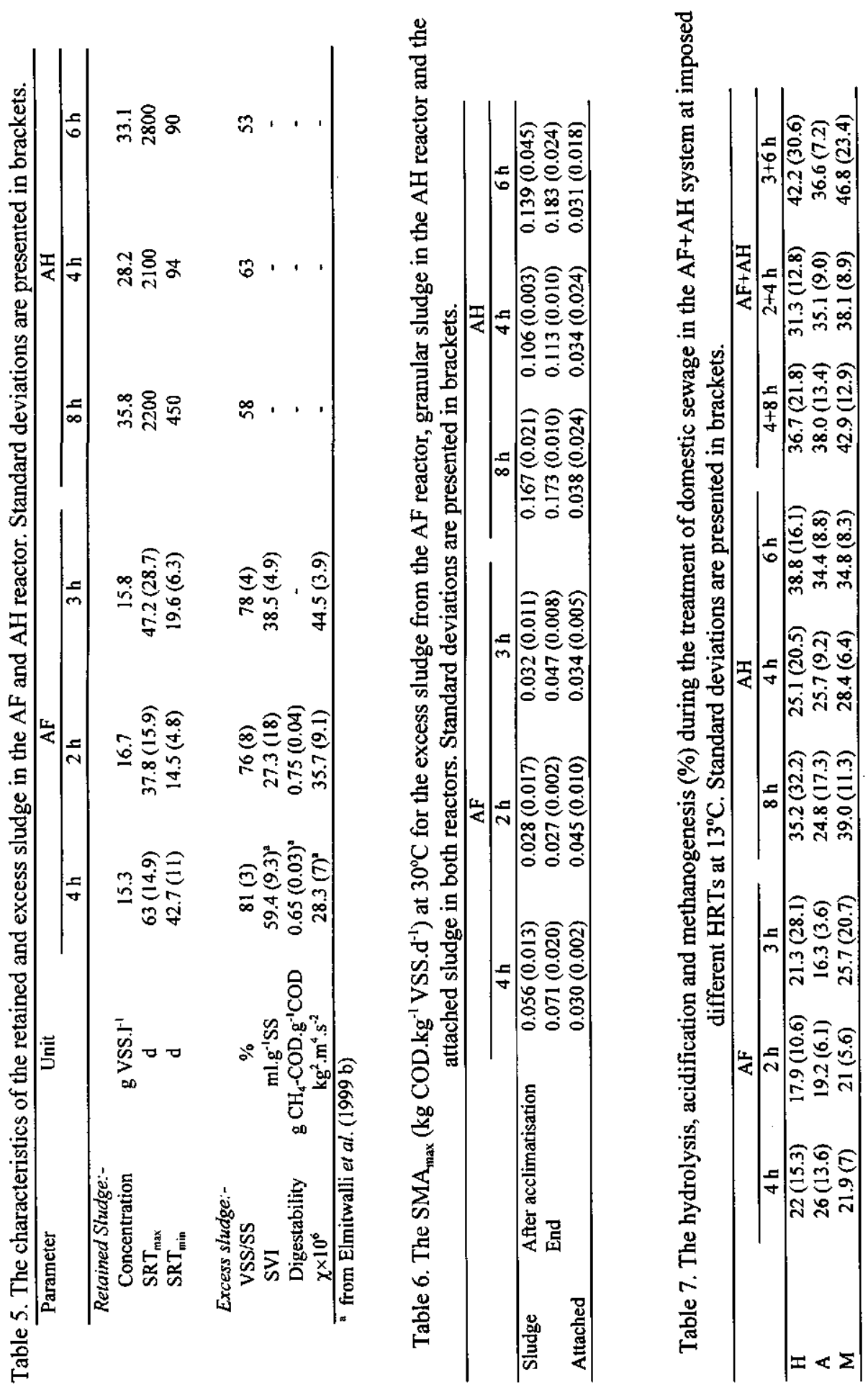


respectively 33 and $35 \%$ for the treatment of domestic sewage in a UASB reactor with granular sludge and operated at an HRT of $4.7 \mathrm{~h}$ at $13^{\circ} \mathrm{C}$.

\section{General discussion}

The results of these investigations reveal that the AF system is highly efficient in removing $\mathrm{COD}_{\mathrm{ss}}$ removal, viz. $81 \%$ of $\mathrm{COD}_{\mathrm{ss}}$ is removed at an imposed HRT of $4 \mathrm{~h}$. Increasing the HRT in the AF reactor above $4 \mathrm{~h}$ will likely increase the $\mathrm{COD}_{\mathrm{ss}}$ removal as shown in Fig. 2.1. For methanogenic activity in the $\mathrm{AH}$ reactor, further removal of $\mathrm{COD}_{\mathrm{ss}}$ has been shown not to be necessary. Moreover, the total $\mathrm{COD}_{\mathrm{ss}}$ removal in the $\mathrm{AF}+\mathrm{AH}$ system has reached to a high value of $91 \%$. Increasing the $\mathrm{HRT}$ of the AF reactor above $4 \mathrm{~h}$ could therefore only slightly improve the $\mathrm{COD}_{\mathrm{ss}}$ removal in the $\mathrm{AF}+\mathrm{AH}$ system. Accordingly, the HRT of $4 \mathrm{~h}$ is recommended for the $\mathrm{AF}$ reactor.

From the results of the $\mathrm{SMA}_{\max }$ for the granular sludge in the $\mathrm{AH}$ reactor, it can be concluded that the $\mathrm{COD}_{\mathrm{ss}}$ loading to the reactor should remain $<0.38 \mathrm{~kg} \mathrm{COD} \mathrm{ss}_{\mathrm{s}} \cdot \mathrm{m}^{-3} \cdot \mathrm{d}^{-1}$ in order to avoid deterioration of the granular sludge $\mathrm{SMA}_{\max }$. The latter loading corresponds to an HRT of $2.3 \mathrm{~h}$ for the AH reactor, when the influent $\mathrm{COD}_{\mathrm{ss}}$ concentration is equal to 36 mg. $l^{-1}$, the effluent value of the AF reactor at an HRT of $4 \mathrm{~h}$. When operated at an HRT of $2+4 \mathrm{~h}$, the $\mathrm{AF}+\mathrm{AH}$ system can provide a $\mathrm{COD}_{\text {dis }}$ removal of $55 \%$ which comprises the maximum achievable $\mathrm{COD}_{\text {dis }}$ removal (Last and Lettinga, 1992). Therefore, when the $A F+A H$ system operated at an HRT of $4+4 \mathrm{~h}$, the $\mathrm{COD}_{\mathrm{ss}}$ and $\mathrm{COD}_{\mathrm{dis}}$ removal can be optimized in both reactor modules without any serious deterioration of the granular sludge $\mathrm{SMA}_{\max }$. When operated at an HRT of $4+8 \mathrm{~h}$, the $\mathrm{AF}+\mathrm{AH}$ system provides, a $\mathrm{COD}_{\text {col }}$ removal of $60 \%$ (mainly achieved in the $\mathrm{AH}$ reactor), which represents $85 \%$ of the maximum achievable $\mathrm{COD}_{\text {col }}$ in anaerobic treatment for domestic sewage, viz. $72 \%$ (Last and Lettinga, 1992). Therefore, under these conditions the $\mathrm{AF}+\mathrm{AH}$ system provides a relatively high removal of all COD fractions with $\mathrm{COD}_{1}$ removal efficiency of $71 \%$ at $13^{\circ} \mathrm{C}$, similar to that found in one step UASB reactors in tropical countries at higher temperatures $>20^{\circ} \mathrm{C}$ (Draaijer et al., 1992; Schellinkout and Osario, 1992). Moreover, 60\% of the removed $\mathrm{COD}$, converted to methane.

\section{CONCLUSIONS}

The AF reactor investigated in the present study represents an efficient pre-treatment process for domestic sewage at $13^{\circ} \mathrm{C}$, i.e. it provides an average removal efficiency for $\mathrm{COD}_{\mathrm{ss}}$ of 81,58 and $57 \%$ at an HRT of respectively 4,2 and $3 \mathrm{~h}$. Considering these results, it is recommended to apply such an AF reactor at an HRT of $4 \mathrm{~h}$ for the pre-treatment of domestic sewage at low temperatures.

A two-step $\mathrm{AF}+\mathrm{AH}$ system operated at an $\mathrm{HRT}$ of $4+8 \mathrm{~h}$ and a temperature of $13^{\circ} \mathrm{C}$ provides a high removal efficiency for all $\mathrm{COD}$ fractions. The achieved $\mathrm{COD}_{\mathrm{t}}$ removal efficiency is as high as $71 \%$, which is very similar to removal efficiencies found for onestep UASB systems in tropical countries.

The $\mathrm{AF}+\mathrm{AH}$ system shows high values for hydrolysis, acidification and methanogenesis. 
These values are similar under different HRTs. $60-74 \%$ of the removed COD, is converted to methane at the imposed HRTs.

The major part of the excess sludge is produced in the AF reactor. Its settlablity and dewaterability are good, but post stabilization is necessary.

The $\mathrm{COD}_{\mathrm{ss}}$ loading of the AH reactor should be $<0.38 \mathrm{~kg} \mathrm{COD} / \mathrm{m}^{3} . \mathrm{d}$ in order to prevent deterioration of the $\mathrm{SMA}_{\max }$ of the granular sludge.

\section{ACKNOWLEDGEMENTS}

We acknowledge the Egyptian Ministry of Higher Education for the scholarship given for the first author and Plan Dienst Verlening, The Netherland for partial financial support of this research. We are grateful to Recticel, Buren, The Netherlands for providing the polyurethane foam sheet. We also are grateful to: R.E. Roersma, B. Willemsen, I. Gerrits, A. Tawfik, J. van der Laan and H. Donker for technical support.

\section{REFERENCES}

Alphenaar A. (1994) Anaerobic granular sludge: characterization and factors affecting its functioning. Ph. D. thesis, Wageningen University, The Netherlands.

Dutch Standard Normalized Methods (1969) The Netherlands Normalisation Institute, Delft, The Netherlands.

Draaijer H., Maas J. A. W., Schaapman J. E. and Khan A. (1992) Performance of the 5 mild UASB reactors for sewage treatment at Kanpur, India. Water Sci. Technol. 25(7), 123133.

Elmitwalli T. A., Zandvoort M., Zeeman G., Bruning H. and Lettinga G. (1999 a) Low temperature treatment of domestic sewage in upflow anaerobic sludge blanket and anaerobic hybrid reactors. Water Sci. Technol. 39(5), 177-185.

Elmitwalli T. A., Sklyar V., Zeeman G. and Lettinga G. (1999 b) Low temperature pretreatment of domestic sewage in anaerobic hybrid and anaerobic filter reactor. Proc. $4^{\text {th }}$ IAWQ Conference in Biofilm System. New York.

Elmitwalli T. A., Dun M. van, Zeeman G., Bruning H., Lettinga G. (2000) The role of filter media in removing suspended and colloidal particles in anaerobic reactor treating domestic sewage. Biores. Technol. 72(3), 235-240.

Elmitwalli T. A., Soellner J., Keizer A. de, Zeeman G., Bruning H., Lettinga G. (submitted) Biodegradability and change of physical characteristics of particles during anaerobic digestion of domestic sewage. Water Res.

Havelaar A. H. and During M. (1988) Evaluation of Anderson Baired-Parker direct plating method for enumerating Escherichia coli in water. $J$. of Applied Bacter. 64, 89-98.

Jirka A. and Carter M. J. (1975) Micro semi-automated analysis of surface and waste waters for chemical oxygen demand. Analytical Chem. 47, 1397-1401.

Kalogo Y. and Verstraete W. (1999) Development of anaerobic sludge bed (ASB) reactor technologies for domestic wastewater treatment: motives and perspectives. World $J$ of 
Microbio. and Biotechnol. 15, 523-534.

Lașt A. R. M. van der and Lettinga G. (1992) Anaerobic treatment domestic sewage under moderate climatic (Dutch) conditions using upflow reactors at increased superficial velocities. Water Sci. Technol, , 25(7), 167-178.

Lettinga G., Roersma R. and Grin P. (1983) Anaerobic treatment of raw domestic sewage at ambient temperatures using a granular bed UASB reactor. Biotechnol. and Bioeng., 25, $1701-1723$.

Lier J. B. van (1995) Thermophilic anaerobic wastewater treatment: temperature aspects and process stability. Ph. D. Thesis, Wageningen University, The Netherlands.

Man A. W. A. de, Grin P. C., Roersma R., Grolle K. C. F. and Lettinga G. (1986) Anaerobic treatment of sewage at low temperatures. Proc. Anaerobic Treatment a Grown-up Technology, Amsterdam, The Netherlands, 451-466.

Miron Y., Zeeman G., Lier J. van, Lettinga G. (2000) The role of sludge residence time in the hydrolysis of lipids, carbohydrates and proteins during the anaerobic treatment of domestic sewage. Water Res. 34(5), 1705-1713.

Uemura S. and Harada H. (2000) Treatment of sewage by a UASB reactor under moderate to low temperature conditions. Biores. Technol. 72(3), 275-283.

Schellinkhout A. and Osario, C. J. (1992) Full-scale application of the UASB technology for sewage treatment. Water Sci. Technol. 25(7), 157-166.

Wang K. (1994) Integrated anaerobic and aerobic treatment of sewage. Ph. D. thesis, Wageningen University, The Netherlands.

Zeeman G., Sanders W. T. M., Wang K. and Lettinga G. (1997) Anaerobic treatment of complex wastewater and waste activated sludge. Application of upflow anaerobic solid removal (UASR) reactor for the removal and pre-hydrolysis of suspended COD. Water Sci. Technol. 35(10), 121-128.

Zeeman G. and Lettinga G. (1999) The Role of anaerobic digestion of domestic sewage in closing the water and nutrient cycle at community level. Water Sci. Technol. 39(5), 187-194. 


\section{Chapter 7}

\section{ANAEROBIC TREATMENT OF DOMESTIC SEWAGE AT LOW TEMPERATURE Summary, discussion, conclusions and recommendations}

Will be presented/submitted as:

Elmitwalli T. A., Zeeman G. and Lettinga, G. (2000) Anaerobic treatment of domestic sewage at low temperature. Will be presented in VI Latin American Workshop and Seminar on Anaerobic Digestion, 5-9 November 2000, Recife, Brazil.

Elmitwalli T. A., Oanh K. L. T., Keizer A. de, Zeeman G. and Lettinga G. (in preparation) Cationic polymers addition to the effluent of anaerobic reactors treating domestic sewage. 


\section{ANAEROBIC TREATMENT OF DOMESTIC SEWAGE AT LOW TEMPERATURE \\ Summary, discussion, conclusions and recommendations}

\section{INTRODUCTION}

When treating domestic sewage at low temperatures in one anaerobic step, the low rate of hydrolysis for the entrapped particulate matter generally will deteriorate the methanogenesis in the reactor. Therefore, a two-step system looks more appropriate for the treatment of domestic sewage at low temperatures (Zeeman and Lettinga, 1999). The aim of the first step is the removal and partial hydrolysis of SS, while the removal and conversion of the remaining COD is delegated to the second (methanogenic) reactor. Wang (1994) found that the first step of a two-step system, a high loaded UASB+ EGSB reactor, achieved a higher total $\mathrm{COD}\left(\mathrm{COD}_{\mathrm{t}}\right)$ removal than the conventional primary sedimentation tank. However, the removal of suspended $\mathrm{COD}\left(\mathrm{COD}_{\mathrm{ss}}\right)$ in the first step amounted to only $44 \%$ at an HRT of $3 \mathrm{~h}$ at $12^{\circ} \mathrm{C}$. Moreover, the removal of colloidal COD $\left(\mathrm{COD}_{\text {col }}\right)$ remained very limited in the UASB+EGSB system. Therefore, improvement of the removal for $\mathrm{COD}_{\mathrm{ss}}$ and $\mathrm{COD}_{\mathrm{col}}$ in the first as well as the second step needs to be investigated. From information available in literature (Chapter 1), it appears that filter material can provide an improvement in the SS removal. Vertical sheets of reticulated polyurethane foam (RPF) were indicated to have a good performance.

This thesis describes the results of research concerning the anaerobic treatment of domestic sewage at low temperature. Firstly, the biodegradability of domestic sewage and its fractions was determined (Chapter 2). Thereafter, the role of the filter media in removing particles in the anaerobic reactor was investigated (Chapter 3). In Chapter 4 , the effect of SS on the performance of a UASB and an anaerobic hybrid (AH) reactor, seeded with granular sludge, was studied by comparing the treatment of raw and pre-settled sewage at a low temperature of $13^{\circ} \mathrm{C}$. After that, a comparison between an anaerobic filter (AF) and an $\mathrm{AH}$ (with flocculant sludge) reactor for the pre-treatment of domestic sewage was carried out (Chapter 5). Based on these results, it was found that the $\mathrm{AF}+\mathrm{AH}$ (with granular sludge) system was a suitable system for the treatment of domestic sewage at low temperatures and the performance of this system was studied with different HRTs (Chapter 6). This last chapter summarizes and discusses the main results of this thesis followed by the main conclusions and recommendations.

\section{ANAEROBIC BIODEGRADABILITY OF DOMESTIC SEWAGE AND ITS FRACTIONS}

The anaerobic biodegradability (conversion to $\mathrm{CH}_{4}$ ) is an important parameter for evaluating the potential of anaerobic treatment of any wastewater. The results in Chapter 2 show a high and similar anaerobic biodegradability of raw sewage $(74 \%)$ at 20 and $30^{\circ} \mathrm{C}$. As also the biodegradability of paper-filtered $(4.4 \mu \mathrm{m})$ and membrane-filtered $(0.45 \mu \mathrm{m})$ sewage was determined, the biodegradability of the fractions of domestic sewage can be calculated. The biodegradability of the colloidal fraction was the highest $(86 \pm 3 \%)$ followed by the suspended fraction $(77 \pm 4 \%$ ), while it was the lowest for the dissolved fraction $(62 \%)$. As the biodegradability of $\mathrm{COD}_{\text {col }}$ is high, the low removal of $\mathrm{COD}_{\mathrm{col}}$ in continuous 
anaerobic reactors at low temperature (Wang, 1994) should be attributed to the low entrapment and/or sorption in the reactors.

\section{THE ROLE OF FILTER MEDIA IN REMOVING PARTICLES DURING THE ANAEROBIC TREATMENT OF DOMESTIC SEWAGE}

Synthetic filter medium showed a high capacity for removing particles (Tanaka $e t$ al., 1995; Odegaard, 1998). The media selected are vertical sheets of RPF with knobs. The RPF was chosen because it represents a highly porous medium with high specific surface area and large pore size. Therefore, RPF can contain an amount of attached sludge as high as 15 gVSS/l. Moreover, the vertical orientation of the RPF sheets with knobs allows the wastewater and produced biogas to move upwards, while the entrapped particles can settle to the bottom of the reactor. This configuration prevents clogging of the filter medium in the anaerobic reactor.

The use RPF media in the anaerobic reactors has been studied by many researchers, like Huysman et al. (1983), Derycke and Verstraete (1986), Gijzen et al. (1988), Rompu et al. (1990), Zaiat et al. (1996) and Ratusznei et al. (2000). Moreover, the RPF media were used in full-scale reactors for both anaerobic (Rompu et al., 1990) and activated sludge (Golla $e t$ $a l ., 1993$ ) processes. Therefore, the durability is long enough and the costs is low enough to apply RPF media in full-scale reactors.

In Chapter 3, the removal of $\mathrm{COD}_{\mathrm{ss}}$ and $\mathrm{COD}_{\mathrm{col}}$ was investigated in an $\mathrm{AF}$ packed with clean vertical sheets of RPF with knobs and fed with either raw or synthetic sewage for a short period of 2.25 HRTs. The results of the experiment prove that clean media are effective in removing $\mathrm{COD}_{\mathrm{ss}}(>75 \%)$ due to physical entrapment and filtration even at an HRT as low as $0.5 \mathrm{~h}$ and an upflow velocity as high as $10 \mathrm{~m} / \mathrm{h}$, but the removal of $\mathrm{COD}_{\text {col }}$ was poor under all experimental conditions.

\section{EFFECT OF SS REMOVAL ON THE ANAEROBIC TREATMENT OF DOMESTIC SEWAGE}

Chapter 3 also describes results of experiments dealing with the operation of a fed-batch recirculation system at a recirculation time of 1 day both for raw and paper-filtered sewage and at a temperature of $24 \pm 1^{\circ} \mathrm{C}$. For the treatment of raw sewage under 'steady state' conditions, the average removal efficiency found for $\mathrm{COD}_{\mathrm{col}}$ was $63 \%$ and for paper-filtered sewage under the same conditions, this amounted to $81 \%$. The lower removal efficiency for $C O D_{c o l}$ when treating raw sewage was attributed to the production of $\mathrm{COD}_{\mathrm{col}}$ from hydrolysis of SS. The same phenomenon was observed in the continuous treatment of domestic sewage in a UASB reactor and an AH reactor with granular sludge bed operated at $13^{\circ} \mathrm{C}$ with an HRT of $8 \mathrm{~h}$, initially with raw sewage for a period of 65 days and next with pre-settled sewage for a period of 100 days (Chapter 4). The treatment of pre-settled sewage instead of raw sewage resulted in a significant increase in $\mathrm{COD}_{\mathrm{col}}$ removal efficiency for both reactors. Under 'steady state' the $A H$ reactor removed significantly more $\mathrm{COD}_{\mathrm{t}}$ from pre-settled sewage than the UASB reactor mainly as a result of the significantly higher removal of $\mathrm{COD}_{\mathrm{col}}$. Based on these results it was concluded that a two-step system should be able to increase both the removal of SS and of colloids. Moreover, the AH reactor with granular sludge bed is recommended for the treatment of pre-treated sewage at low temperatures. 


\section{A SUITABLE PRE-TEATMENT SYSTEM}

Chapter 5 describes the pre-treatment (removal of $\mathrm{COD}_{\mathrm{ss}}$ ) of raw domestic sewage at a temperature of $13^{\circ} \mathrm{C}$ and an HRT of $4 \mathrm{~h}$ in an $\mathrm{AF}$ reactor and in an $\mathrm{AH}$ (with flocculant sludge bed) reactor. The packing medium in the AF and in the top of the AH reactor consisted of vertical sheets of RPF with knobs. The biomass in the AF was only present in attached form because all accumulated sludge in the bottom of the reactor was discharged weekly from the system in order to avoid reactor clogging. In the $\mathrm{AH}$ reactor, the sludge bed was controlled by wasting the sludge from the top of the sludge bed. The AF reactor showed a higher $\mathrm{COD}_{t}$ removal $(55 \%)$ and $\mathrm{COD}_{s \mathrm{~s}}$ removal $(82 \%)$ as compared to both the $\mathrm{AH}$ reactor and the high loaded UASB reactor operated by Wang (1994). Moreover, the performance of the $\mathrm{AF}$ was more stable especially in rainy periods. Because the $\mathrm{AF}$ and $\mathrm{AH}$ reactor were operated at a short HRT and a low temperature, the extent of hydrolysis, acidification and methanogenesis remained quite limited. The stability of the excess sludge produced in the $\mathrm{AH}$ reactor was better and it had a higher settlability and dewaterability than that produced in the AF reactor. However, the excess sludge from the $\mathrm{AH}$ reactor also needs post stabilization. Therefore, we recommend the AF reactor packed with vertical sheet of RPF with knobs for the pre-treatment of domestic sewage at low temperatures.

\section{LOW TEMPERATURE TREATMENT OF DOMESTIC SEWAGE IN A TWO-STEP SYSTEM: AF+AH REACTOR}

Based on above-mentioned results, we concluded that a suitable configuration for the treatment of domestic sewage at low temperature consists of an $\mathrm{AF}$ reactor followed by an $\mathrm{AH}$ reactor. In Chapter 6 , such a system was tested for a period of about 300 days under conditions of different HRTs, viz. $4+8,2+4$ and $3+6 \mathrm{~h}$, and at a temperature of $13^{\circ} \mathrm{C}$. The results showed that the AF reactor indeed was efficient in the removal of $\mathrm{COD}_{\mathrm{ss}}$ (especially with HRT of $4 \mathrm{~h}$ ) and the AH reactor was efficient in the removal of $\mathrm{COD}_{\mathrm{col}}$ and dissolved $\mathrm{COD}\left(\mathrm{COD}_{\mathrm{dis}}\right)$. Regarding the low temperature, the combined $\mathrm{AF}+\mathrm{AH}$ system showed a high removal efficiency for $\mathrm{COD}_{\mathrm{t}}$ (Fig. 1), even at an HRT of $2+4 \mathrm{~h}(59 \%)$. The system also provided relatively high values for hydrolysis, acidification and methanogenesis.

The excess sludge wasted from the system mainly was produced in the AF reactor. The maximum specific methanogenic activity $\left(\mathrm{SMA}_{\max }\right)$ of the granular sludge in the $\mathrm{AH}$ reactor remained stable at a value of about $0.18 \mathrm{~kg}$ COD $/ \mathrm{kg}$ VSS.d at an imposed HRT of the AH reactor of 6 and $8 \mathrm{~h}$, while it dropped to $0.11 \mathrm{~kg} \mathrm{COD} / \mathrm{kg}$ VSS.d at an HRT of $4 \mathrm{~h}$. Therefore, $\mathrm{COD}_{\mathrm{ss}}$ loading for the second step should not exceed that of the AH reactor with an HRT of $6 \mathrm{~h}\left(<0.38 \mathrm{~kg} \mathrm{COD} s / \mathrm{m}^{3} . \mathrm{d}\right)$ in order to prevent deterioration of the $\mathrm{SMA}_{\max }$. At pre-treatment of domestic sewage in an AF reactor at an HRT of $4 \mathrm{~h}$, a $\mathrm{COD}_{\mathrm{ss}}$ loading of $0.38 \mathrm{~kg} \mathrm{COD} s \mathrm{~s} / \mathrm{m}^{3} . \mathrm{d}$ will be achieved at an HRT of $2.3 \mathrm{~h}$ for the AH reactor. Therefore, an HRT of $4+4 \mathrm{~h}$ seems long enough for optimization of $\mathrm{COD}_{\mathrm{ss}}$ and $\mathrm{COD}_{\text {dis }}$ removal in the $\mathrm{AF}+\mathrm{AH}$ system and to prevent deterioration of the $\mathrm{SMA}_{\max }$ of the granular sludge. However, an HRT of $8 \mathrm{~h}$ is needed for the $\mathrm{AH}$ reactor to also optimize the $\mathrm{COD}_{\text {col }}$ removal. The AF+AH system operated at an HRT of $4+8 \mathrm{~h}$ at a low temperature of $13^{\circ} \mathrm{C}$ showed high removal efficiencies for all $C O D$ fractions and achieved a $\operatorname{COD}_{\mathrm{t}}$ removal as high as $71 \%$, which is similar to that found in tropical countries with constant-high temperatures.

However, despite the high COD, removal of $71 \%$ at an $\mathrm{HRT}$ of $4+8 \mathrm{~h}$ at $13^{\circ} \mathrm{C}$, the removal of $E$-coli and obviously also of nutrient remain limited. For regions where nutrient removal 
is not necessary, like still the case in many developing countries, post treatment is only needed for reducing the $\mathrm{COD}_{\mathrm{t}}$ and pathogens depending on the effluent discharge standards. As, the average effluent $\mathrm{COD}_{t}$ of the $\mathrm{AF}+\mathrm{AH}$ system operated at an HRT of $4+8$ $\mathrm{h}$ at $13^{\circ} \mathrm{C}$ is $133 \mathrm{mg} / \mathrm{l}$, the operational costs of the combined $\mathrm{AF}+\mathrm{AH}$ and post-treatment system remain low as compared to the aerobic treatment of domestic sewage, without anaerobic pre-treatment. Several types of reactors have been proposed as a post-treatment system for anaerobic effluent (Collivignarelli et al., 1990; Garuti et al., 1992; Machdar et al., 1997; Agrawal et al., 1997; Araki et al., 1999). Machdar et al. (1997) treated the effluent of an UASB reactor by cubes of RPF, hanged vertically, and called a downflow hanging sponge-cubes (DHS) system. They found that the UASB+DHS system is an efficient process in removing $\operatorname{COD}_{t}(94 \%)$ and providing nitrification $(73-78 \%)$ at a short HRT of $7+1.3 \mathrm{~h}$ and at $25^{\circ} \mathrm{C}$. Preliminary research (results not shown) in a trickling filter using vertical sheets of RPF with knobs as a medium for the treatment of the AF+AH system effluent shows similar results. In addition to the reduced investment and operational costs when using an $\mathrm{AF}+\mathrm{AH}$ system for pre-treatment of domestic sewage, application of a trickling filter system with RPF vertical sheets with knobs as post treatment system, implies less mechanical equipment and energy for aeration and sludge (or wastewater) recirculation as compared to the conventional aerobic systems. The effluent of the $\mathrm{AF}+\mathrm{AH}$ system after post-treatment is a valuable product for irrigation and fertilization, especially for regions suffering from a lack of water resources like in the Middle East. The necessity and extent of additional pathogens removal depends on the crops and irrigation system applied.

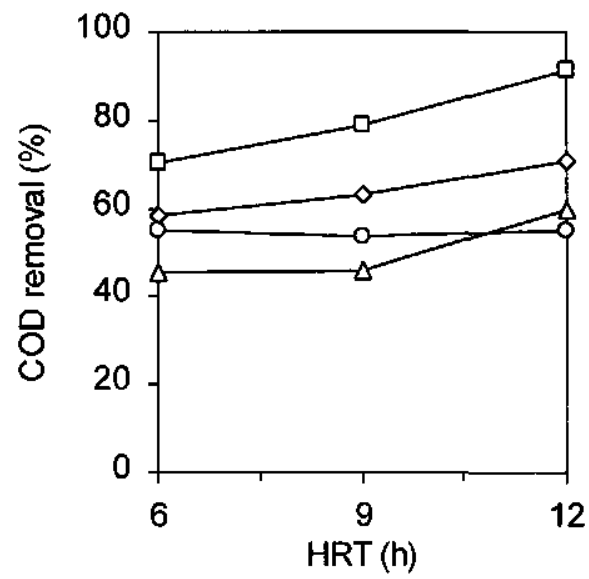

Fig. 1. Effect of HRT on the removal of $\mathrm{COD}_{\mathrm{t}}$ and its fractions during the treatment of domestic sewage in the AF+AH system at $13^{\circ} \mathrm{C} .(1) .(\diamond), \mathrm{COD}_{\mathrm{t}} ;(\square), \mathrm{COD}_{\mathrm{ss}} ;(\triangle), \mathrm{COD}_{\mathrm{col}}$; (O), $\mathrm{COD}_{\mathrm{dis}}$.

The effluent of the $\mathrm{AF}+\mathrm{AH}$ system is too low in carbon content to apply subsequent nitrogen removal. When nutrient removal is obligatory, a different system configuration should be chosen in which the $\mathrm{AH}$ reactor or alternative is operated as a denitrifying reactor, making use of the carbon present in the effluent of the AF reactor. The AF reactor operated at an $\mathrm{HRT}$ of $4 \mathrm{~h}$ at $13^{\circ} \mathrm{C}$ removed $45-55 \%$ of domestic sewage $\mathrm{COD}_{\mathrm{t}}$, mainly as a result of its high $\mathrm{COD}_{\mathrm{ss}}$ removal efficiency (80-82\%). Also these values are higher than applying a conventional primary sedimentation tank and approach these obtained in the physical chemical pre-treatment processes. Moreover, partial hydrolysis and acidification 
occur in the $\mathrm{AF}$ reactor, which might improve the nutrient removal. Andersson and Rosen (1990) and Karlsson and Smith (1991) found that although the pre-treatment decreases the $\mathrm{COD}_{t} / \mathrm{N}$ ratio, the denitrification was hardly affected, as the remaining organic fraction after pre-treatment results in the highest denitrification rate. Loosdrecht et al. (1997) studied the overall environmental impact of nutrient removal processes depending on the pre-treatment of sewage by primary clarification and discovered a drastic decrease in energy consumption if a pre-treated sewage was used. Application of anaerobic pretreatment of domestic sewage followed by nutrient removal processes might be a better solution than the application of primary clarification prior to the nutrient removal processes.

\section{POSSIBILITY OF FURTHER IMPROVEMENT OF COLLOIDAL PARTILCES REMOVAL DURING THE ANAEROBIC TREATMENT OF DOMESTIC SEWAGE AT LOW TEMPERATURES}

The results in Chapter 2 revealed a high biodegradability of colloidal particles present in domestic sewage. So, a poor entrapment and/or sorption of colloidal particles in the continuous-anaerobic reactor is the obstacle for their removal and then conversion. Moreover, a higher removal of colloidal particles will be accompanied with a higher removal of pathogens because most of pathogens are associated with colloidal particles (Chapter 6). As biomass and colloidal particles both have a negative charge, addition of small amounts of a cationic polymer to the influent of the second step (AH reactor) might improve the removal of $\mathrm{COD}_{\mathrm{col}}$ by either 1) increase of the size of colloidal particles by bridging phenomena and then increase the entrapment and sorption of particles in the $\mathrm{AH}$ reactor; or 2) changing the charge of the particles to positive by coating the particles with cationic polymer and hence stimulating the sorption of these coated particle to the negative biomass.

The addition of a cationic polymer to the effluent of the AF reactor was investigated in batch tests. Two types of cationic polymers were selected, QNHEC and C492 HMW. The results reveal that the two polymers have the same effect on the zeta-potential and the particle size (Fig. 2). Addition of small amounts of polymer, i.e. as low as $1 \mathrm{mg} / \mathrm{l}$, significantly increased the size of the particles, viz. respectively 2 and 3.5 times for 0.5 and $1 \mathrm{mg}$ QNHEC/l. A high dose of cationic polymer is required (> $25 \mathrm{mg} / \mathrm{l}$, Fig. 2.2) to change the zeta-potential of the colloidal particles to positive or zero. Batch test results indicate that the QNHEC does not affect the activity of the granular sludge and is partially biodegradable. Therefore, addition of a small amount of cationic polymer likely will improve the entrapment and sorption of particles in the AH reactor as a result of increase in the size of the particles. However, this needs to be investigated in continuous experiments.

In comparing such a system with a system of pre-precipitation of suspended and colloidal particles using cationic polymers, the proposed system might have a lower demand of chemicals as the main part of the particles has already been removed in the AF reactor.

\section{CONCLUSIONS}

- The anaerobic biodegradability of the colloidal fraction present in domestic sewage is the highest $(86 \%)$, followed by the suspended fraction (77\%), while it is the lowest for the dissolved fraction (62\%). Therefore, the low removal of $\mathrm{COD}_{\mathrm{col}}$ in continuous 
anaerobic reactors at low temperature must be attributed to its low entrapment and/or sorption in the reactor, and not to low biodegradability.

- By removing SS in the first-step of two-step system not only the deterioration of the activity of the sludge in the second step is prevented, but also the removal of colloidal particles in the second step is improved.

- An AF reactor, packed with vertical RPF sheets with knobs, offers a high potential for removing $\mathrm{COD}_{\mathrm{ss}}(82 \%)$ from raw domestic sewage when operated at a low temperature of $13^{\circ} \mathrm{C}$ and an HRT of $4 \mathrm{~h}$.

- A two-step $A F+A H$ system can provide a $\operatorname{COD}_{t}$ removal efficiency as high as $71 \%$ at an HRT of $4+8 \mathrm{~h}$ when applied to raw domestic sewage at $13^{\circ} \mathrm{C}$.


Fig. 2. Effect of cationic polymer on the average particle radius and zeta-potential for the effluent of the AF reactor operated at HRT of $3 \mathrm{~h}$ and at $13^{\circ} \mathrm{C}$ treating domestic sewage. (口) C492 HMW; (0), QNHEC.

\section{RECOMMENDATION}

- Application of the two-step, $\mathrm{AF}+\mathrm{AH}$, system for domestic sewage treatment at low temperatures needs to be investigated on a large scale. Also, for higher temperatures, the feasibility of the system needs to be investigated

- Addition of small amounts of cationic polymer for optimization of the removal and conversion of colloidal particles in the second step (AH reactor) with short HRT needs to be studied in a continuous system.

- The financial and operational benefits of anaerobic pre-treatment of domestic sewage in the $\mathrm{AF}$ reactor (and may be in the $\mathrm{AH}$ reactor also) on the nutrient removal in the posttreatment processes need to be explored.

\section{REFERENCES}

Andersson B. and Rosen B. (1990) Upgrading for biological nitrogen removal- some full scale experinces from Sweden. Water Sci. Technol. 22(7/8) 93-104. 
Araki N., Ohashi A., Machdar I. and Harada H. (1999) Behaviors of nitrifiers in a novel biofilm reactor employing hanging sponge-cubes as attachment site. Water Sci. Technol. 39(7), 21-31.

Argawal L. K., Ohashi Y., Mochida E., Okui H., Ueki Y., Harada H. and Ohashi A. (1997) Treatment of raw sewage in a temperature climate using a UASB reactor and the hanging sponge cubes process. Water Sci. Technol. 36(6/7), 433-440.

Collivignarelli C., Urbini G., Farneti A., Bassetti A. and Barbaresi U. (1990) Anaerobic aerobic treatment of municipal wastewaters with full-scale upflow anaerobic sludge blanket and attached biofilm reactors Water Sci. Technol. 22(1/2), 475-482.

Derycke D. and Verstraete W. (1986). Anaerobic treatment of domestic wastewater in a lab and pilot scale polyurethane carrier reactor. Proc. Anaerobic Treatment a Grown-up Technology, Amsterdam, The Netherlands, 437-450.

Garuti G., Dohanyos M. and Tilche A. (1992) Anaerobic-aerobic combined process for the treatment of sewage with nutrient removal: The ananox Process. Wat. Sci. Technol. 25(7), 383-394.

Gijzen H. J., Schoenmakers T. J. M., Caerteling C. G. M. and Vogels G. D. (1988) Anaerobic degradation of papermill sludge in a two-phase digester containing rumen microorganisms and colonized polyurethane foam. Biotechnol. Lett. 10, 61-66.

Golla P. S., Reddy M. P., Simms M. K. and Laken T. J. (1994) Three years of full-scale Captor process operation at Moundsville WWTP. Water Sci. Technol. 29(10/11), 175181.

Huysman P., Meenen P. van, Assche P. van and Verstraete W. (1983) Factors affecting the colonization of non porous and porous packing materials in model upflow methane reactors. Biotechol. Lett., 5(9), 643-648.

Karlsson I. and Smith G. (1991) Pre-precipitation facilities nitrogen removal without tank expansion. Water Sci. Technol. 23, 811 -817.

Loosdrecht M. C. M. van, Kuba T., Veldhuizen H. M. van, Brandse F. A. and Heijnen J. J. (1997) Environmental impacts of nutrient removal processes: case study. $J$. of Environmental Eng. 123(1), 33-40.

Machdar I, Harada H., Ohashi A., Sekiguchi Y., Okui H. and Ueki K. (1997) A novel and cost-effective sewage treatment system consisting of UASB pre-treatment and aerobic post-treatment units for developing countires. Water Sci. Technol.36(12), 1890197.

Odegaard H. (1998) Optimised particle separation in the primary step of wastewater treatment. Water Sci. Technol. 37(10), 43-53.

Rompu K. van, D'Haene S. and Verstraete (1990) Mass transport in anaerobic polyurethane carrier reactor. Process Biochem. 25(1), 3-6.

Ratusznei S. M., Rodrigues J. A. D., Camargo E. F. M., Zaiat M. and Borzani W. (2000) Feasibility of a stirred anaerobic sequencing batch reactor containing immobilized biomass for wastewater treatment. Biores. Technol. 75(2), 127-132.

Tanaka Y., Miyajima K., Funakosi T. and Chida S. (1995) Filtration of municipal sewage by ring shaped floating plastic net media. Water Res. 29(5), 1387-1392.

Wang K. (1994) Integrated anaerobic and aerobic treatment of sewage. Ph. D. thesis, Department of Environmental Technology, Wageningen University, The Netherlands.

Zaiat M., Cabral A. K. A and Foresti E. (1996) Cell wash-out and external mass transfer resistance in horizontal-flow anaerobic immobilized sludge reactor. Water Res. 30(10), 2435-2439.

Zeeman G. and Lettinga G. (1999) The role of anaerobic digestion of domestic sewage in closing the water and nutrient cycle at community level. Water Sci. Technol. $39(5), 187-194$. 


\section{ANAËROBE BEHANDELING VAN HUISHOUDELIJK AFVALWATER BIJ LAGE TEMPERATUREN \\ Samenvatting, discussie, conclusies en aanbevelingen}




\section{ANAËROBE BEHANDELING VAN HUISHOUDELIJK AFVALWATER BIJ LAGE TEMPERATUREN \\ Samenvatting, discussie, conclusies en aanbevelingen}

\section{INLEIDING}

Vaak wordt afvalwater in één enkele anaërobe reactor behandeld. Echter, indien dit principe ook wordt toegepast voor huishoudelijk afvalwater bij lage temperaturen, zal de methanogenese in de reactor volledig worden bepaald door de lage snelheid waarmee ingevangen gesuspendeerd materiaal wordt gehydrolyseerd. Zeeman en Lettinga (1999) adviseren onder deze condities daarom een systeem dat uit twee opeenvolgend reactoren bestaat. In de eerste reactor wordt gesuspendeerd materiaal uit het afvalwater verwijderd en gedeeltelijk gehydrolyseerd. In de tweede (methanogene) reactor kan vervolgens het resterende CZV worden omgezet. Wang (1994) heeft laten zien dat in de eerste trap van een tweetraps UASB+EGSB systeem een betere verwijdering van totaal $\mathrm{CZV}(\mathrm{CZV})$ optrad dan in een conventionele voorbezinker. Echter, bij een hydraulische verblijftijd (HVT) van 3 uur en een temperatuur van $12{ }^{\circ} \mathrm{C}$ was het verwijderingsrendement voor gesuspendeerd $\mathrm{CZV}$ $\left(\mathrm{CZV}_{\mathrm{ss}}\right)$ slechts $44 \%$. Ook de verwijdering van collö̈daal $\mathrm{CZV}\left(\mathrm{CZV}_{\mathrm{col}}\right)$ in het gecombineerde UASB+EGSB systeem liet te wensen over. Hieruit volgt dan ook dat mogelijkheden waarmee de verwijdering van $\mathrm{CZV}_{\mathrm{ss}}$ en $\mathrm{CZV}_{\text {col }}$ verbeterd zou kunnen worden verder moeten worden onderzocht. Zo is uit de literatuur bekend dat met bepaalde filtermaterialen, bijvoorbeeld verticaal geplaatste matten van polyurethaan (PUR), de verwijdering van $\mathrm{CZV}_{\mathrm{ss}}$ sterk kan worden verbeterd (Hoofdstuk 1).

Dit proefschrift beschrijft onderzoeksresultaten die hetrekking hebben op de anaërobe behandeling van huishoudelijk afvalwater bij lage temperaturen. In de eerste plaats werden de (anaërobe) biodegradeerbaarheid van het gebruikte afvalwater en van de verschillende fracties van dit afvalwater bepaald (Hoofdstuk 2). Vervolgens werd de rol van filtermateriaal bij de verwijdering van gesuspendeerde stoffen onderzocht (Hoofdstuk 3). In Hoofdstuk 4 werd het effect van gesuspendeerde stof op het rendement van een UASB en een anaërobe hybride (AH) reactor onderzocht door deze reactoren, beide geënt met korrelslib, met ruw en met voorbezonken afvalwater te voeden. Vervolgens werden een anaëroob filter (AF) en een AH reactor (met gesuspendeerde biomassa) met elkaar vergeleken (Hoofdstuk 5). Op basis van de resultaten van Hoofdstukken 4 en 5 werd geconcludeerd dat een tweetraps $\mathrm{AF}+\mathrm{AH}$ systeem (Ah met korrelslib) het beste systeem is voor de behandeling van huishoudelijk afvalwater bij lage temperaturen. Daarom werd in Hoofdstuk 6 het rendement van dit systeem onderzocht bij verschillende HVTs. Dit laatste hoofdstuk geeft een samenvatting van de belangrijkste resultaten en een discussie van die resultaten. Tenslotte worden de belangrijkste conclusies gegeven en een aantal aanbevelingen gedaan.

\section{ANAËROBE BIODEGRADEERBAARHEID VAN HUISHOUDELIJK AFVALWATER EN DE FRACTIES IN DIT AFVALWATER}

De anaërobe biodegradeerbaarheid van een afvalwater (omzetting naar methaan, $\mathrm{CH}_{4}$ ) is zeer belangrijk omdat dit de basis vormt voor een evaluatie van de mogelijkheid om dat afvalwater anaëroob te behandelen. De resultaten in Hoofdstuk 2 lieten zien dat de anaërobe biodegradeerbaarheid van ruw afvalwater bij 20 en bij $30^{\circ} \mathrm{C}$ gelijk was aan $74 \%$. Omdat ook 
de biodegradeerbaarheid van papier-gefiltreerd $(4.4 \mu \mathrm{m})$ en membraan-gefiltreerd $(0.45 \mu \mathrm{m})$ afvalwater werd bepaald, kon ook de biodegradeerbaarheid van de verschillende fracties worden berekend. Deze was het hoogst voor de colloïdale fractie $(86 \pm 3 \%)$, gevolgd door de gesuspendeerde fractie ( $77 \pm 4 \%$ ). Gezien de hoge biodegradeerbaarheid van $\mathrm{CZV}_{\text {col }}$, moet het lage verwijderingsrendement van deze fractie in anaërobe reactoren (Wang, 1994) worden toegewezen aan de geringe invang en/of adsorptie in het slib-bed.

\section{DE ROL VAN FILTERMATERIAAL BIJ DE VERWIJDERING VAN DEELTJES TIJDENS ANAËROBE BEHANDELING VAN HUISHOUDELIJK AFVALWATER}

Met synthetisch filtermateriaal kan een goede verwijdering van deeltjes bewerkstelligd (Tanaka et al., 1995; Ødegaard, 1998). Het geselecteerde filtermateriaal bestond uit verticaal geplaatste PUR-matten voorzien van noppen, vooral omdat dit materiaal een hoge porositeit en een hoog specifiek oppervlak heeft. Hierdoor kan het materiaal zelfs slibconcentraties van $15 \mathrm{~g} / \mathrm{l}$ nog vasthouden. Daarnaast laten de PUR-matten een opwaartse stroom van afvalwater en het daaruit geproduceerd biogas toe, terwijl tegelijkertijd de deeltjes kunnen bezinken. Op deze manier wordt verstopping van het filtermateriaal voorkomen.

Het gebruik van PUR-materiaal is door diverse wetenschappers onderzocht, waaronder Huysman et al. (1983), Derycke en Verstraete (1986), Gijzen et al. (1988), Rompu et al. (1990), Zaiat et al. (1996) en Ratusznei et al. (2000). Ook is het materiaal reeds op praktijkschaal toegepast in anaërobe processen (Rompu et al., 1990), maar ook in actiefslibsystemen (Golla et al., 1993). Blijkbaar zijn de duurzaamheid en de kosten van het PUR-materiaal dermate gunstig dat praktijktoepassingen mogelijk zijn.

In Hoofdstuk 3 werd de verwijdering van $\mathrm{CZV}_{\mathrm{ss}}$ en $\mathrm{CZV}_{\text {col }}$ onderzocht in een $\mathrm{AF}$ reactor die was gepakt met schone, verticaal geplaatste PUR-matten. De reactor werd gedurende een korte periode ( 2.25 maal de HVT) met ruw huishoudelijk afvalwater en met synthetisch afvalwater gevoed. De resultaten lieten zien dat het schone filtermateriaal door zijn filtrerende werking een hoog verwijderingsrendement geeft voor $\mathrm{CZV}_{\text {ss }}(75 \%)$, zelfs bij een HVT van slechts 0.5 uur en een opwaartse snelheid van maar liefst $10 \mathrm{~m} / \mathrm{h}$. Echter, onder alle experimentele omstandigheden werd een slechte verwijdering van $\mathrm{CZV}_{\mathrm{col}}$ waargenomen.

\section{EFFECT VAN DE VERWIJDERING VAN GESUSPENDEERDE STOF OP DE ANAËROBE BEHANDELING VAN HUISHOUDELIJK AFVALWATER}

In Hoofdstuk 3 werden ook de resultaten beschreven van experimenten met een 'fed-batch' recirculatiesysteem (recirculatietijd van $1 \mathrm{dag}$ ) dat met ruw en papier-gefiltreerd afvalwater werd gevoed bij een temperatuur van $24 \pm 1{ }^{\circ} \mathrm{C}$. Onder stationaire condities werd van het ruwe afvalwater $63 \% \mathrm{CZV}_{\text {col }}$ verwijderd en van het papier-gefiltreerde afvalwater $81 \%$. De hogere verwijdering van $\mathrm{CZV}_{\text {col }}$ in het papier-gefiltreerde afvalwater werd toegeschreven aan de hydrolyse van gesuspendeerde stof waarbij $\mathrm{CZV}_{\text {col }}$ wordt geproduceerd. Hieruit kon geconcludeerd worden dat een tweetraps-systeem zowel gesuspendeerde als colloïdale stof kan verwijderen. Hetzelfde fenomeen werd ook bij de continue behandeling van huishoudelijk afvalwater in een UASB reactor en een $\mathrm{AH}$ reactor bij $13{ }^{\circ} \mathrm{C}$ en een HVT van $8 \mathrm{~h}$ geconstateerd (Hoofdstuk 4). Deze reactoren werden gedurende een periode van $65 \mathrm{~d}$ gevoed met ruw afvalwater en dit werd gevolgd werd door een periode van $100 \mathrm{~d}$ met voorbezonken 
afvalwater. Dit laatste resulteerde voor beide reactoren in een verbetering van de $C Z V_{\text {col }}$ verwijdering. Onder stationaire condities verwijderde de $\mathrm{AH}$ reactor aanzienlijk meer $\mathrm{CZV}_{\mathrm{t}}$ dan de UASB reactor, voornamelijk als gevolg van de hogere $\mathrm{CZV}_{\text {col }}$ verwijdering. Op basis van bovenstaande resultaten wordt voor lage temperaturen een $\mathrm{AH}$ reactor aanbevolen voor de nabehandeling van voorbehandeld huishoudelijk afvalwater.

\section{EEN GESCHIKT VOORBEHANDELINGSSYSTEEM}

Hoofdstuk 5 beschrijft de voorbehandeling van ruw huishoudelijk afvalwater (ten behoeve van de verwijdering van $C Z V_{s s}$ ) bij een temperatuur van $13{ }^{\circ} \mathrm{C}$ en een $H V T$ van $4 \mathrm{~h}$ in een $A F$ reactor en in een $\mathrm{AH}$ reactor (met gesuspendeerd slib). Zowel in de AF reactor als bovenin de AH reactor werden verticale PUR-matten met noppen als pakkingsmateriaal gebruikt. De biomassa in de AF reactor was alleen in aangehechte vorm aanwezig omdat wekelijks, om verstoppingen te voorkomen, alle slib dat zich op de bodem van de reactor had verzameld werd gespuid. Het slib-bed in de $\mathrm{AH}$ reactor werd in de hand gehouden door slib te spuien dat zich aan de bovenkant van het bed bevond. De AF reactor vertoonde een betere $\mathrm{CZV}$ verwijdering $(55 \%)$ en SS-verwijdering $(82 \%)$ dan de AH reactor en dan de hoogbelaste UASB reactor die door Wang (1994) werd gebruikt. Bovendien functioneerde de AF reactor stabieler, vooral tijdens periodes met regenweeraanvoer. Omdat de $\mathrm{AF}$ en $\mathrm{AH}$ reactor bij een korte HVT en een lage temperatuur werden bedreven, waren de hydrolyse, de verzuring en de methanogenese beperkt. Het spuislib dat in de AH reactor werd geproduceerd was verder gestabiliseerd en was beter ontwaterbaar dan het slib dat in de AF reactor werd geproduceerd. Echter, ook het spuislib van de AH reactor behoeft een verdergaande stabilisatie. Het wordt aanbevolen om bij lage temperaturen de $\mathrm{AF}$ reactor te gebruiken voor de voorbehandeling van huishoudelijk afvalwater.

\section{BEHANDELING VAN HUISHOUDELIJK AFVALWATER BIJ LAGE TEMPERATUREN IN EEN TWEE-TRAPS SYSTEEM: AF+AH REACTOR}

Op basis van de hierboven beschreven resultaten concludeerden we dat bij lage temperaturen een $\mathrm{AF}$ reactor gevolgd door een $\mathrm{AH}$ reactor een geschikte configuratie is voor de behandeling van huishoudelijk afvalwater. In Hoofdstuk 6 werd dit systeem gedurende een periode van 300 dagen getest bij een temperatuur van $13^{\circ} \mathrm{C}$ en bij verschillende HVTs: $4+8 \mathrm{~h}$, $2+4 \mathrm{~h}$ en 3+6 h. Zoals verwacht vertoonde de $\mathrm{AF}$ reactor een zeer goede verwijdering van $\mathrm{CZV}_{\text {ss }}$ (in het bijzonder bij een HVT van $4 \mathrm{~h}$ ) en was de AH reactor geschikt voor de verwijdering van $C Z V_{\text {col }}$ en opgelost $\mathrm{CZV}\left(\mathrm{CZV}_{\mathrm{dis}}\right)$. Ondanks de lage temperatuur gaf het gecombineerde $\mathrm{AF}+\mathrm{AH}$ systeem een relatief hoog verwijderingsrendement voor $\mathrm{CZV}$, (Fig. 1), zelfs bij een HVT van $2+4 \mathrm{~h}(59 \%)$. Daarnaast vertoonde het systeem een relatief goede hydrolyse, verzuring en methanogenese.

Het grootste deel van het spuislib werd in de AF reactor geproduceerd. De maximale specifieke methanogene activiteit $\left(\mathrm{SMA}_{\max }\right.$ ) van het korrelslib in de $\mathrm{AH}$ reactor was redelijk stabiel met een gemiddelde van $0.18 \mathrm{kgCZV} / \mathrm{kg}$ VSS.d bij een HVT van 6 en $8 \mathrm{~h}$. Echter, bij een HVT van $4 \mathrm{~h}$ daalde de SMA max $_{\text {naar }} 0.11 \mathrm{kgCZV} / \mathrm{kg}$ VSS.d. Dus, om een daling van de $\mathrm{SMA}_{\max }$ in de $\mathrm{AH}$ te voorkomen, mag de $\mathrm{CZV}_{\mathrm{ss}}$-belasting van de tweede trap de belasting bij een HVT van $6 \mathrm{~h}$ niet overschrijden $\left(0.38 \mathrm{~kg} \mathrm{CZV}_{\mathrm{ss}} / \mathrm{m}^{3} . \mathrm{d}\right)$. Indien de voorgeschakelde AF reactor een HVT van $4 \mathrm{~h}$ heeft, wordt een $\mathrm{CZV}_{\text {ss }}$ belasting van $0.38 \mathrm{~kg} / \mathrm{m}^{3} . \mathrm{d}$ verkregen bij een 
HVT van $2.3 \mathrm{~h}$ voor de AH reactor. Dus, een HVT van $4+4$ uur lijkt voldoende voor een optimale verwijdering van $\mathrm{CZV}_{\mathrm{ss}}$ en $\mathrm{CZV}_{\text {dis }}$ en is tegelijkertijd voldoende om een daling van de $\mathrm{SMA}_{\max }$ van het korrelslib in de AH reactor te voorkomen. Bij een HVT van $4+8 \mathrm{~h}$ en een temperatuur van $13{ }^{\circ} \mathrm{C}$ liet het $\mathrm{AF}+\mathrm{AH}$ systeem een hoog verwijderingsrendement zien voor alle CZV fracties en een verwijderingsrendement voor $C Z V_{t}$ van $71 \%$. Dit is vergelijkbaar met rendementen die zijn gevonden in tropische landen waar de gemiddelde temperatuur veel hoger is.

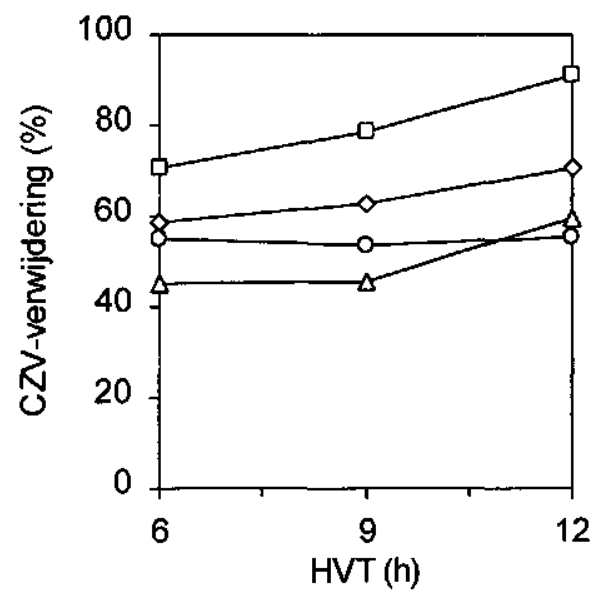

Fig. 1. Effect van de HVT op de verwijdering van $C Z V_{1}$ and $C Z V$-fracties tijdens de behandeling van huishoudelijk afvalwater in het $\mathrm{AF}+\mathrm{AH}$ systeem bij $13^{\circ} \mathrm{C}$. (1). ( $(0), \mathrm{CZV}_{\mathrm{i}}$; (口), $\mathrm{CZV}_{s s} ;(\Delta), \mathrm{CZV}_{\text {cot }} ;(\mathrm{O}), \mathrm{CZV}_{\text {dis }}$.

Hoewel een hoog $\mathrm{CZV}_{\mathrm{t}}$-verwijderingsrendement mogelijk is, worden $E$-coli en nutriènten niet of nauwelijks in het $\mathrm{AF}+\mathrm{AH}$ systeem verwijderd. Voor gebieden waar nutriëntenverwijdering geen vereiste is, zoals in de meeste ontwikkelingslanden, is afhankelijk van de effluenteisen nabehandeling alleen nog maar nodig om het $\mathrm{CZV}$, nog verder te reduceren en pathogenen te verwijderen. Het gemiddelde $\mathrm{CZV}_{\mathrm{t}}$ in het effluent van het $\mathrm{AF}+\mathrm{AH}$ systeem is bij een HVT van $4+8 \mathrm{~h}$ slechts $133 \mathrm{mg} / \mathrm{l}$ en dus zijn de verwachte operationele kosten van het totale systeem (inclusief de nabehandelingsstap) laag in vergelijking met een volledige aërobe behandeling van huishoudelijk afvalwater. Diverse soorten reactoren zijn voorgesteld voor de nabehandeling van anaëroob voorbehandeld afvalwater (Cllivignarelli et al., 1990; Garuti et al., 1992; Machdar et al., 1997; Agrawal et al., 1997, Araki et al., 1999). Machdar et al. (1997) behandelden het effluent van een UASB reactor met PUR-blokjes die verticaal werden opgehangen. Zij lieten zien dat dit systeem, in combinatie met een voorgeschakelde UASB, op zeer efficiënt wijze $C Z V$, kan verwijderen en bij $25^{\circ} \mathrm{C}$ en een HVT van slechts $7+1.3 \mathrm{~h}$ bovendien een nitrificatierendement van $73-78 \%$ geeft. Vooronderzoek met een oxidatiebed met verticaal geplaatste PUR-matten gaf soortgelijke resultaten (resultaten niet getoond). Naast de lagere stichtings- en operationele kosten van een $\mathrm{AF}+\mathrm{AH}$ systeem, zou dit systeem in combinatie met een oxidatiebed, ook minder mechanische onderdelen en energie voor beluchting vergen dan conventionele aërobe systemen. $\mathrm{Na}$ aërobe nabehandeling is het effluent van een $\mathrm{AF}+\mathrm{AH}$ systeem een waardevol product dat voor irrigatie gebruikt kan 
worden, vooral in regio's waar water een schaars goed is zoals in het Midden-Oosten. De noodzaak voor pathogenen-verwijdering hangt sterk af van het verbouwde gewas en het type irrigatiesysteem dat wordt gebruikt.

Het effluent van het $\mathrm{AF}+\mathrm{AH}$ systeem bevat te weinig koolstof om de stikstof in het afvalwater volledig te kunnen verwijderen. Dus, indien nutriëntenverwijdering noodzakelijk is moet voor een ander systeem gekozen worden waarin de AH reactor (of een soortgelijke reactor) wordt uitgevoerd als denitrificatiereactor die van de koolstof in het effluent van de $\mathrm{AF}$ reactor gebruik maakt. De AF reactor bij een HVT van $4 \mathrm{~h}$ en een temperatuur van $13{ }^{\circ} \mathrm{C}$ verwijderde

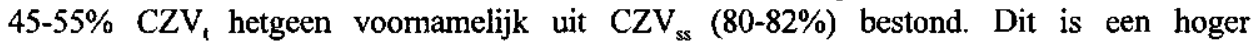
verwijderingsrendement dan met een conventionele voorbezinker bereikt kan worden en benadert de verwijdering die met fysisch-chemische processen mogelijk is. Een extra voordeel is dat in een AF reactor gedeeltelijke hydrolyse en verzuring optreedt hetgeen de nutriëntenverwijdering zou kunnen stimuleren. Andersson en Rosen (1990) en Karlsson en Smith (1991) toonden aan dat door voorbehandeling de $C Z V, N$ verhouding wordt verlaagd maar dat dit geen negatief effect heeft op de denitrificatiesnelheid omdat het $C Z V_{1}$ dat overblijft voornamelijk uit eenvoudig afbreekbare stoffen bestaat. Van Loosdrecht $e t$ al. (1997) bestudeerden de milieu-effecten van nutriënten-verwijdering en ontdekten dat een drastische reductie in het energieverbruik mogelijk is indien een voorbezinker wordt toegepast. Toepassing van een anaërobe voorbehandelingsstap is wellicht een nog betere optie.

\section{DE MOGELIJKHEID VOOR VERDERE VERBETERING VAN DE VERWIJDERING VAN COLLOÏDALE DEELTJES TIJDENS DE ANAËROBE BEHANDELING VAN HUISHOUDELIJK AFVALWATER BIJ LAGE TEMPERATUREN}

De resultaten van Hoofdstuk 2 lieten zien dat de colloïdale deeltjes in huishoudelijk afvalwater onder anaërobe condities goed afgebroken kunnen worden. Hieruit volgt dat de slechte invang en/of sorptie van de colloïdalen in continu bedreven anaërobe reactoren het belangrijkste obstakel is voor hun verwijdering. Een extra motivatie om de verwijdering van colloidale deeltjes te verbeteren is dat tegelijkertijd pathogenen worden verwijderd die aan de colloïdale deeltjes zijn gehecht (Hoofdstuk 6). Omdat zowel biomassa als collö̈dale deeltjes een negatieve lading bezitten zou de toevoeging van kleine hoeveelheden kationisch polymeer aan het influent van de tweede trap van een $A F+A H$ systeem de verwijdering van $C Z V_{\text {col }}$ sterk kunnen verbeteren omdat (1) de brugvorming die door het polymeer wordt veroorzaakt grotere colloïdale deeltjes geeft die vervolgens beter kunnen worden ingevangen of kunnen worden geadsorbeerd en (2) door omlading van de collö̈dale deeltjes hun adsorptie aan de biomassa wordt bevorderd.

Toevoeging van een kationisch polymeer aan het effluent van de AF reactor werd bestudeerd in batchgewijze testen. Twee soorten polymeer werden gebruikt: QNHEC en C492 HMW. De resultaten lieten zien dat deze twee polymeren vrijwel hetzelfde effect op de zeta-potentiaal en de deeltjesgrootte hebben (Fig 2). Toevoeging van kleine hoeveelheden polymeer, d.w.z. minder dan $1 \mathrm{mg} / \mathrm{l}$, gaf een aanzienlijke vergroting van de deeltjes, te weten 2 en $3 \frac{1}{2}$ keer de oorspronkelijke grootte bij een dosering van 0.5 en $1 \mathrm{mg} / \mathrm{l}$ QNHEC/l. Een hogere dosis kationisch polymeer ( $>25 \mathrm{mg} / \mathrm{l}$, Fig. 1.2) was nodig om de colloïdale deeltjes te neutraliseren of zelfs een positieve lading te geven. Andere testen hebben laten zien dat QNHEC de 
activiteit van korrelslib niet negatief beïnvloedt en gedeeltelijk afbreekbaar is. De toevoeging van kleine hoeveelheden kationisch polymeer zal de invang en adsorptie van colloïdale deeltjes in de $\mathrm{AH}$ reactor dus bevorderen. Echter, dit moet verder worden onderzocht in continue experimenten.

In vergelijking met een volledige voorbehandeling met kationische polymeren zijn voor het hierboven voorgestelde systeem minder polymeren vereist omdat het grootste deel van de deeltjes reeds in de $\mathrm{AF}$ reactor is verwijderd.
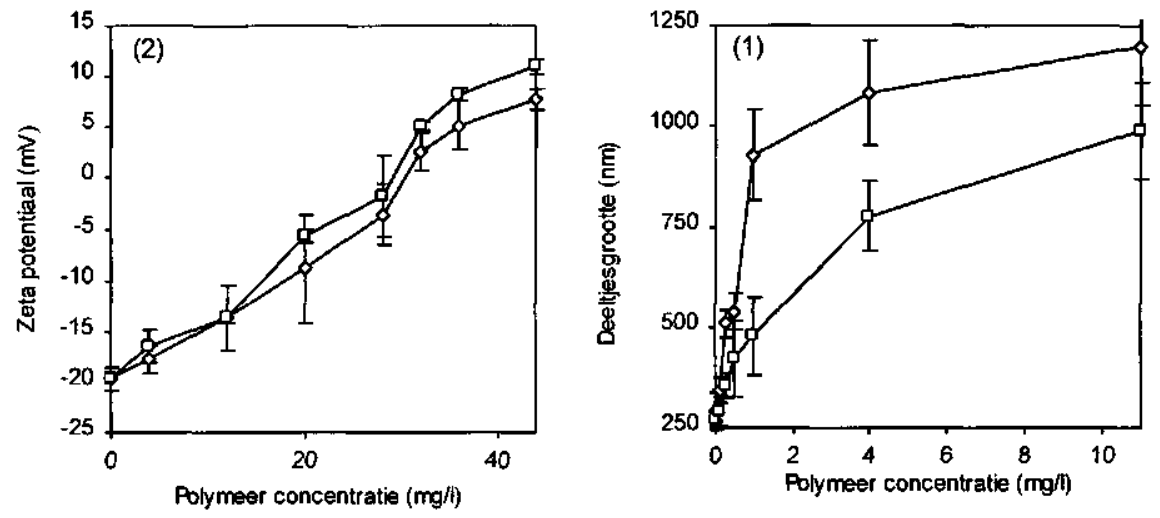

Fig 2. Effect van een kationisch polymeer op de gemiddelde deeltjesgrootte en zeta-potentiaal voor het effluent van de AF reactor die met huishoudelijk afvalwater wordt bedreven bij een temperatuur van $13^{\circ} \mathrm{C}$ en een HVT van $3 \mathrm{~h}$. (口) C492 HMW; ( () , QNHEC

\section{CONCLUSIES}

- De anaërobe biodegradeerbaarheid van de colloïdale fractie in huishoudelijk afvalwater is het hoogst (82\%), gevolgd door de gesuspendeerde fractie $(77 \%)$ en de opgeloste fractie (62\%). Hieruit volgt dat de slechte verwijdering van $C Z V_{\text {col }}$ in continue anaërobe reactoren bij lage temperaturen moet worden toegewezen aan de slechte invang en/of sorptie van deze fractie.

- Door gesuspendeerde stof in de eerste trap van een tweetraps-systeem te verwijderen ontstaat een hoge activiteit in de tweede trap en wordt de verwijdering van colloïdale deeltjes in de tweede stap bevorderd.

- Met een AF reactor met verticale PUR-matten met noppen kan een zeer hoge verwijdering van $\mathrm{CZV}_{\mathrm{ss}}(82 \%)$ bewerkstelligd worden uit huishoudelijk afvalwater, zelfs bij een lage temperatuur $\left(13^{\circ} \mathrm{C}\right)$ en een relatief korte HVT van $4 \mathrm{~h}$.

- Met een tweetraps $\mathrm{AF}+\mathrm{AH}$ systeem kan $71 \% \mathrm{CZV}$, verwijderd worden bij een temperatuur van $13^{\circ} \mathrm{C}$ en een HVT van $4+8 \mathrm{~h}$.

\section{AANBEVELINGEN}

- De toepassing van een tweetraps $\mathrm{AF}+\mathrm{AH}$ systeem voor huishoudelijk afvalwater bij lage temperaturen moet verder worden onderzocht op praktijkschaal. Ook de haalbaarheid van dit systeem bij hogere temperaturen moet worden onderzocht. 
- De toevoeging van kleine hoeveelheden kationisch polymeer om de verwijdering en omzetting van colloïdale deeltjes in de tweede stap van het systeem (de $\mathrm{AH}$ reactor) te verbeteren moet worden onderzocht bij een kleine HVT.

- De financiële en operationele voordelen van de anaërobe voorbehandeling van huishoudelijk afvalwater in een AF reactor (en eventueel ook in de $A H$ reactor) op de nutriëntenverwijdering moet nader worden onderzocht.

\section{REFERENTIES}

Andersson B. en Rosen B. (1990) Upgrading for biological nitrogen removal- some full scale experiences from Sweden. Water Sci. Technol. 22(7/8) 93-104.

Araki N., Ohashi A., Machdar I. en Harada H. (1999) Behaviors of nitrifiers in a novel biofilm reactor employing hanging sponge-cubes as attachment site. Water Sci. Technol. $39(7), 21-31$.

Argawal L. K., Ohashi Y., Mochida E., Okui H., Ueki Y., Harada H. en Ohashi A. (1997) Treatment of raw sewage in a temperature climate using a UASB reactor and the hanging sponge cubes process. Water Sci. Technol. 36(6/7), 433-440.

Collivignarelli C., Urbini G., Farneti A., Bassetti A. en Barbaresi U. (1990) Anaerobic aerobic treatment of municipal wastewaters with full-scale upflow anaerobic sludge blanket and attached biofilm reactors Water Sci. Technol. 22(1/2), 475-482.

Derycke D. en Verstraete W. (1986). Anaerobic treatment of domestic wastewater in a lab and pilot scale polyurethane carrier reactor. Proc. Anaerobic Treatment a Grown-up Technology, Amsterdam , The Netherlands, 437-450.

Garuti G., Dohanyos M. en Tilche A. (1992) Anaerobic-aerobic combined process for the treatment of sewage with nutrient removal: The ananox Process. Wat. Sci. Technol. 25(7), 383-394.

Gijzen H. J., Schoenmakers T. J. M., Caerteling C. G. M. en Vogels G. D. (1988) Anaerobic degradation of papermill sludge in a two-phase digester containing rumen microorganisms and colonized polyurethane foam. Biotechnol. Lett. 10, 61-66.

Golla P. S., Reddy M. P., Simms M. K. en Laken T. J. (1994) Three years of full-scale Captor process operation at Moundsville WWTP. Water Sci. Technol. 29(10/11), 175-181.

Karlsson I. en Smith G. (1991) Pre-precipitation facilities nitrogen removal without tank expansion. Water Sci. Technol. 23, 811-817.

Huysman P., Meenen P. van, Assche P. van en Verstraete W. (1983) Factors affecting the colonization of non porous and porous packing materials in model upflow methane reactors. Biotechol. Lett., 5(9), 643-648.

Loosdrecht M. C. M. van, Kuba T., Veldhuizen H. M. van, Brandse F. A. en Heijnen J. J. (1997) Environmental impacts of nutrient removal processes: case study. $J$. of Environmental Eng. 123(1), 33-40.

Machdar I, Harada H., Ohashi A., Sekiguchi Y., Okui H. en Ueki K. (1997) A novel and costeffective sewage treatment system consisting of UASB pre-treatment and aerobic posttreatment units for developing countires. Water Sci. Technol. 36(12), 1890197.

Odegaard H. (1998) Optimised particle separation in the primary step of wastewater treatment. Water Sci. Technol. 37(10), 43-53.

Rompu K. van, D'Haene S. en Verstraete (1990) Mass transport in anaerobic polyurethane carrier reactor. Process Biochem. 25(1), 3-6. 
Ratusznei S. M., Rodrigues J. A. D., Camargo E. F. M., Zaiat M. en Borzani W. (2000) Feasibility of a stirred anaerobic sequencing batch reactor containing immobilized biomass for wastewater treatment. Biores. Technol. 75(2), 127-132.

Tanaka Y., Miyajima K., Funakosi T. en Chida S. (1995) Filtration of municipal sewage by ring shaped floating plastic net media. Water Res. 29(5), 1387-1392.

Wang K. (1994) Integrated anaerobic and aerobic treatment of sewage. $\mathrm{Ph}$. D. thesis, Department of Environmental Technology, Wageningen University, The Netherlands.

Zaiat M., Cabral A. K. A en Foresti E. (1996) Cell wash-out and external mass transfer resistance in horizontal-flow anaerobic immobilized sludge reactor. Water Res. 30(10), 2435-2439.

Zeeman G. en Lettinga G. (1999) The role of anaerobic digestion of domestic sewage in closing the water and nutrient cycle at community level. Water Sci. Technol. 39(5),187194. 


\section{Curriculum vitae}

The author of this dissertation, Tarek Abdel-Hamid Elmitwalli, was born on the $20^{\text {th }}$ February 1964 in Egypt. In 1987, he obtained his Bachelor of Science degree from the Department of Civil Engineering of the Faculty of Engineering, Mansoura University. In 1992, he obtained his Master of Science degree in sanitary engineering from the same department of Civil Engineering. He is employed at the Department of Civil Engineering of the Benha High Institute of Technology, Egypt. In October 1994, he got a scholarship from the Egyptian Ministry of High Education to study in The Netherlands. In November 1995, he came to The Nehterlands and started his Ph. D. study at the Sub-Department of Environmental Technology of the Wageningen University.

His address in Egypt is:-

Tarek Abdel-Hamid Elmitwalli

Department of Civil Engineering,

Benha High Institute of Technology,

P. O. Box 13512

Benha El-Gedida,

Benha,

Egypt.

E-mail:t_elmitwalli@hotmail.com 